UCRL-51027

Distribution Category UC-702

UCRL --51027

DE91 004908

\title{
Radioecological Studies Related to the BANEBERRY Event
}

\author{
J.J. Koranda \\ P.L. Phelps \\ L.R. Anspaugh \\ G.B. Potter \\ W. Chapman \\ K.O. Hamby \\ K.R. Peterson \\ T.V. Crawford \\ in cooperation with
}

R.C. Pendleton, University of Utah

Manuscript date: March 1, 1971

\section{LAWRENCE LIVERMORE NATIONAL LABORATORY}

University of California $\cdot$ Livermore, California $\bullet 94550$

\section{Available to DOE and DOE contractors from the Office of Scientific and Technical Information \\ P.O. Box 62, Oak Ridge, TN 37831 - Prices available from (615) 576-8601, FTS 626-8401}

Available from: National Technical Service - U.S. Department of Commerce

5285 Port Royal Road - Springfield, VA 22161 - A04 - (Microfiche A01) 


\section{Foreword}

This report of radioecological studies following the BANEBERRY venting was written in 1971 when Lawrence Livermore National Laboratory was known as the Lawrence Radiation Laboratory (LRL) and the Environmental Sciences Division of the Biomedical and Environmental Research Program was part of the (then) BioMedical Research Division. The report contains original calculations that have not been published elsewhere. 


\section{Preface}

The BANEBERRY event was an underground weapons test conducted at the Nevada Test Site on the morning of December 18, 1970. Venting occurred with this detonation, producing a cloud of radioactivity that moved over central and northern Nevada into Utah.

In 1969, the LRL Bio-Medical Research Division had initiated cooperative radioecological studies with the University of Utah Department of Radiological Health that were designed to document the distribution and movement of radionuclides in the agricultural and natural environments of Utah. These studies were implemented by radioanalyses of environmental samples obtained from 16 sampling stations located throughout the state. As part of the scheduled sampling program, the sequential-air-sampling network was activated on October 30, 1970, and operated for a six-week period, ending December 11, 1970. The timing of this sampling period was fortuitous; not only was the air-sampling network in a state of readiness when the BANEBERRY event occurred, but the results of this survey established the existing levels of background radioactivity in Utah. Therefore, it was possible to assess fully the radioactivity contributed to this area by the BANEBERRY event.

The meteorological conditions during the passage of the BANEBERRY debris cloud through Utah were not unusual, but were fairly typical of winter weather for days when the wind flow is toward the north or northeast. Virtually no precipitation was encountered by the upper portions of the debris cloud during its passage through Utah. The near-ground portion of the cloud (between the surface and about 6500 feet) initially drifted very slowly in a northward direction. Lack of adequate meteorological observations makes it impossible to develop a meaningful trajectory for this part of the cloud. However, it is likely that portions of this nearsurface debris cloud moved over northern Utah on December 20th and 21st and were removed as both wet and dry deposition at low levels of activity. 


\section{Contents}

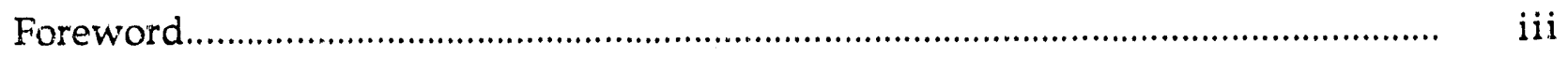

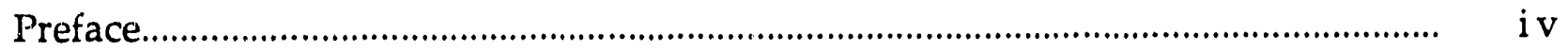

List of Tables................................................................................................. vi

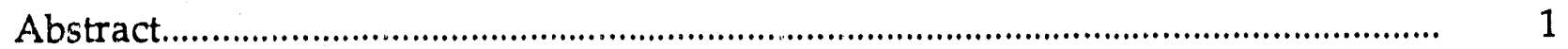

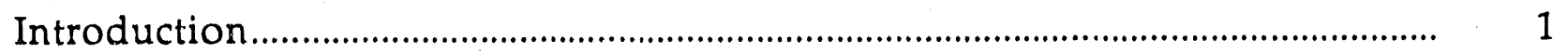

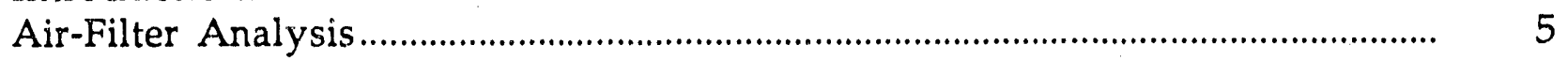

Air-Sampling Method .......................................................................... 5

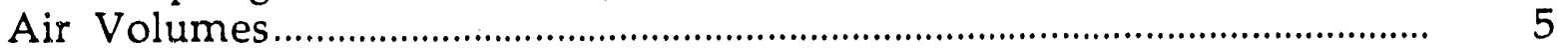

Gamma-Ray Analysis ............................................................................ 5

Iodine-131 Concentrations in Animal Thyroid Glands ...................................... 7

Analysis of Snow Samples........................................................................... 11

Evaluation of Radiological Hazards ................................................................ 12

Inhalation and Submersion Dose .............................................................. 12

Dose from Food-Chain Contamination........................................................ 13

Dose Estimate When Dairy Cows Consume Fresh Feed

or Green Chop .............................................................................................. 14

Dose Estimate When Dairy Cows Do Not Consume

Fresh Feed............................................................................................... 21

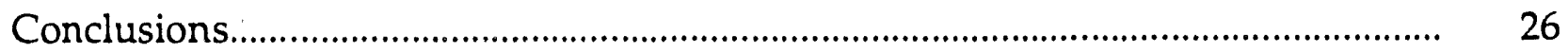

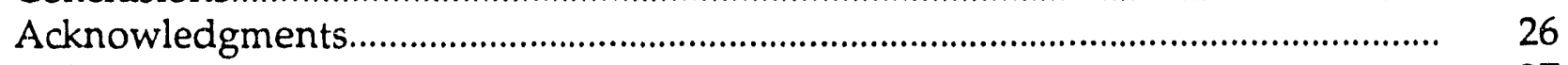

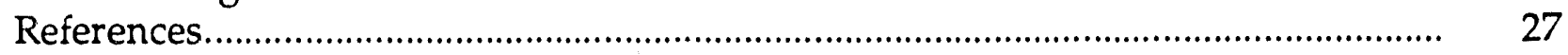

Appendix A:

BANEBERRY Meteorological Data and Interpretation

for Eastern Nevada and Utah.

Appendix B:

Air-Filter Data from Fifteen Collection Sites in Utah

B-1

Appendix C:

Preliminary Results on Selected Samples of

Biological Materials from Nevada Test Site.

C-1 


\section{List of Tables}

1. Sites in Utah where LRL and University of Utah airsampling equipment was in operation, BANEBERRY event, December 18 to 28,1970 .

2. Summary of the data recorded by Southwestern Radiological Health Laboratory on the partitionir:g of radioiodine between particulate filters and charcoal cartridges in Idaho, Montana, and Utah.

3. Sheep, deer, and jackrabbit thyroid gland 131 I concentrations after the BANEBERRY event, December 20 to 26, 1970 .

4. Deer and sheep thyroid gland ${ }^{131}$ I concentrations after the BANEBERRY event, December 22 to 29, 1970

5. Tritium content of snow samples collected in Utah, December 30-31, 1970

6. Integrated ${ }^{131}$ I air activity measured in Utah

7. Comparison of integrated air activity at Utah Station 1 to AEC Concentration Guidance for continuous exposure integrated over one year

8. Estimated dose from inhalation or submersion at Station 1, Draper, Utah

9. Values of radionuclide-independent parameters and radionuclide-dependent parameters necessary to evaluate the radioiodine model, assuming dairy cows are on fresh feed.

10. Estimated dosage to a child through the forage-cow-milk pathway for a hypothetical dry deposition based upon integrated air activity measured or estimated at Station 1 ..................................

11. Summary of predicted doses in rad to a child's thyroid for the hypothetical situation that dairy cows were on fresh feed and the integrated air activity was the same as actually occurred

12. Modified values of parameters necessary to evaluate stored feed radioiodine moclel.

13. Summary of predicted doses to a child's thyroid for the actual conditions of the BANEBERRY vent 


\title{
Radiological Studies Related to the BANEBERRY Event
}

\begin{abstract}
On December 18, 1970, at 7:30 a.m. PST, a venting occurred at the Nevada Test Site in conjunction with the BANEBERRY test. The Lawrence Radiation Laboratory (LRL) Bio-Medical Research Division and the University of Utah responded to this event by activating their jointly operated air-sampling network and by gathering forage, milk, and animal samples. These data are used to calculate the dose to humans from inhalation, submersion, and food-chain contamination; food-chain contamination calculations are limited to the cow-milk pathway, but included bovine inhalation. The question of food-chain contamination is explored under both the actual situation that dairy cows were fed stored feed and under the hypothetical situation that dairy cows were fed fresh feed. Our results show that 131I was the significant radionuclide emitted by the event and that the strongest dose was received by the thyroid glands of 'Joth foraging animals and humans. The integrated concentrations of 131I were higher in the northern part of Utah; the maximum value of $1100 \mathrm{pCi} \mathrm{h} \mathrm{m}^{-3}$ was recorded at Draper (near Salt Lake City). For conservative results, we calculated the dose to a child rather than an adult. For the actual conditions following the venting, we estimate on the basis of measurements of baled hay and or milk that the dose to an infant's thyroid via the cow-milk pathway was between 0.0065 and 0.012 rad at Draper. If cows had been continuously on fresh pasture, we estimate that the dose to the infant thyroid for the same integrated air concentration would have been 1.3 rad for dry deposition and up to 100 rad for wet deposition.
\end{abstract}

\section{Introduction}

The LRL Bio-Medical Research Division and the Utah State Division of Health notified the University of Utah Department of Radiological Health at 9:00 a.m. MST on December 18, 1970, that a venting had occurred at the Nevada Test Site (NTS) at 7:30 a.m. PST. This notification initiated a planned program of environmental sampling designed to document and assess the effects within the State of Utah of a 
release of radioactivity from the NTS. Additionally, information on the probable trajectory of the fallout cloud was provided. On the same day (December 18, 1970), LRL personnel were dispatched to the University of Utah to assist with the collection of environmental samples and with the evaluation of the levels of environmental radioactivity. Details of the procedures employed in monitoring the radioactivity released by the BANEBERRY event are reported by Pendleton et al. ${ }^{1}$

On December 19, 1970, University of Utah and LRL Bio-Medical personnel began to assemble the information that was being received from the statewide system of air monitors. A map of the State of Utah showing the location of the sequential air samplers (SAS) is shown in Fig. 1. Several stations in the Salt Lake City area had been activated, and filters were ready for analysis on December 19th. The locations and descriptions of the stations are listed in Table 1.

By late afternoon on December 19th, the levels of airborne radioactivity shown on the air monitor at the University of Utah campus in Salt Lake City were in the range of $1000 \mathrm{pCi} \mathrm{m}^{-3}$. The data shown in Fig. 2 were obtained from the Eberline AIM-3 gross radiation monitor located on the Salt Lake City campus. These data indicate that cloud-arrival time in Salt Lake City was approximately at 8:00 to 9:00 a.m. MST on December 19, 1970. This is substantiated by the meteorological data presented in Appendix A of this report. By 4:00 p.m. on December 19th, the

Table 1. Sites in Utah where LRL and University of Utah (U. of U.) air-sampling equipment was in operation, BANEBERKY event, December 18 to 28, 1970.

\begin{tabular}{|c|c|c|c|c|c|c|c|}
\hline $\begin{array}{l}\text { Station } \\
\text { number }\end{array}$ & $\begin{array}{c}\text { Nearest } \\
\text { town }\end{array}$ & $\begin{array}{l}\text { Mile } \\
\text { azir } \\
\text { from }\end{array}$ & $\begin{array}{l}\text { and } \\
\text { huth } \\
\text { NTS }\end{array}$ & $\begin{array}{c}\text { Type of } \\
\text { farm or site }\end{array}$ & $\begin{array}{l}\text { Number of } \\
\text { livestock }\end{array}$ & $\begin{array}{l}\text { LRL } \\
\text { SAS }^{a}\end{array}$ & $\begin{array}{l}\text { U. of U. } \\
\text { Ebcrline } \\
\text { AIM-3 } 3^{a}\end{array}$ \\
\hline 1 & Draper & 320 & $46^{\circ}$ & Poultry & 0 & $x$ & $x$ \\
\hline 4 & Magna & 320 & $43^{\circ}$ & Dairy & 80 & $x$ & $x$ \\
\hline 9 & Snyderville & 340 & $47^{\circ}$ & Dairy & 50 & $x$ & $x$ \\
\hline 33 & Ephraim & 290 & $60^{\circ}$ & Dairy & 30 & $x$ & $x$ \\
\hline 40 & Monroe & 240 & $68^{\circ}$ & Dairy & 50 & $x$ & $x$ \\
\hline 45 & Cedar City & 170 & $81^{\circ}$ & Cattle/sheep & $200 / 500$ & $x$ & $x$ \\
\hline 48 & St. George & 140 & $95^{\circ}$ & College campus & - & $x^{\prime}$ & $x$ \\
\hline 49 & Milford & 190 & $67^{\circ}$ & Airport & - & $x$ & $x$ \\
\hline 57 & Bridgeland & 370 & $58^{\circ}$ & Dairy & 120 & $x$ & $x$ \\
\hline 61 & Delta & 240 & $54^{\circ}$ & Sugar beet and alfalfa & - & $x$ & 0 \\
\hline 63 & Wellington & 330 & $63^{\circ}$ & Dairy & 80 & $x$ & $x$ \\
\hline 68 & Bluebell & 380 & $56^{\circ}$ & Dairy & 150 & $x$ & $x$ \\
\hline 71 & Cornish & 390 & $35^{\circ}$ & Dairy & 100 & $x$ & $x$ \\
\hline 78 & Logan & 380 & $36^{\circ}$ & Dairy & 40 & $x$ & 0 \\
\hline $80 A^{b}$ & Grouse Creek & 330 & $22^{\circ}$ & Cattle & 150 & $x$ & $x$ \\
\hline 90 & Wendover & 260 & $27^{\circ}$ & Air Force base & - & $x$ & $x$ \\
\hline $\mathrm{CP}$ & Salt Lake City & 330 & $44^{\circ}$ & U. of U. campus & - & - & $x$ \\
\hline
\end{tabular}




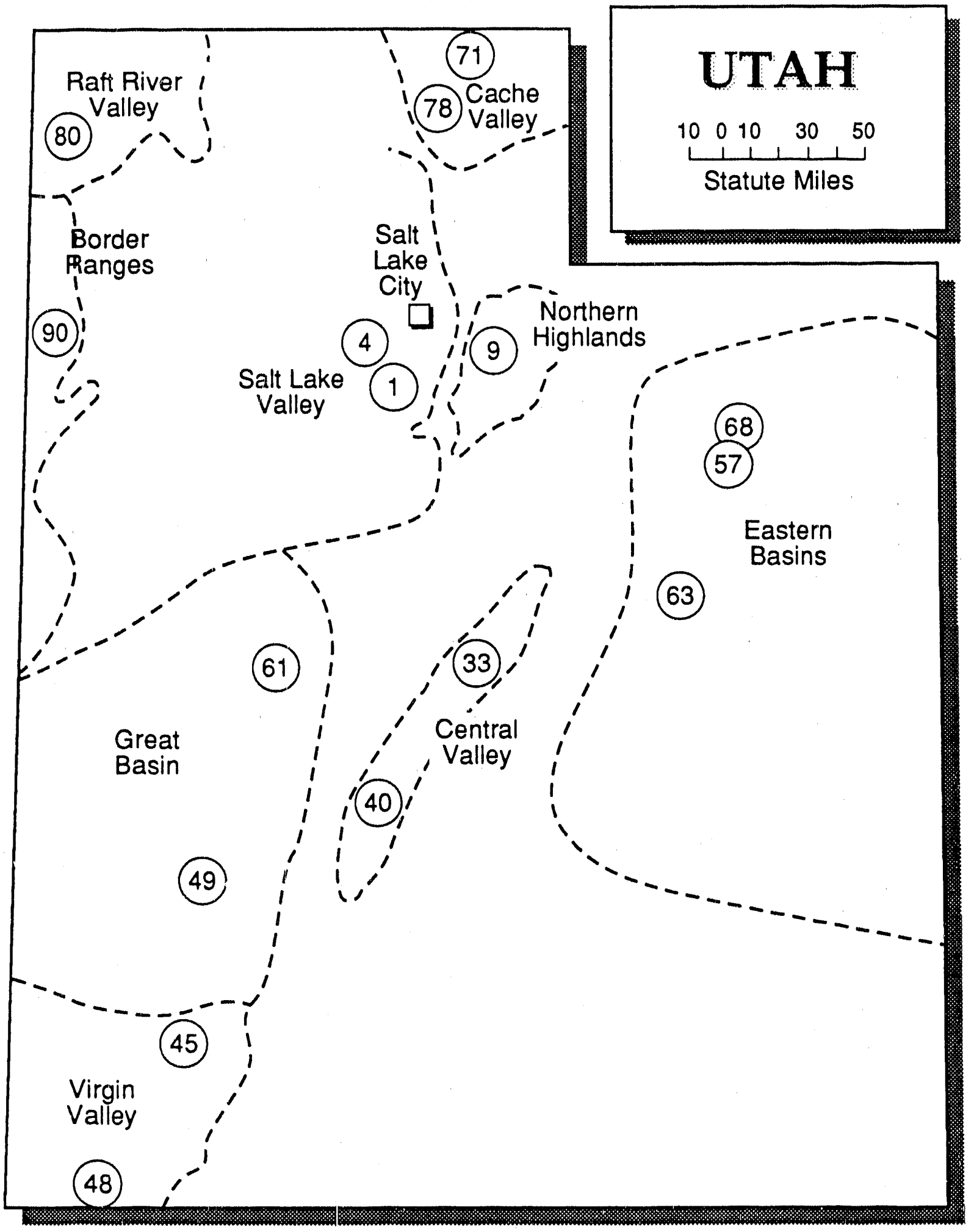

Figure 1. Map of Utah showing the locations of air-sampling sites. 


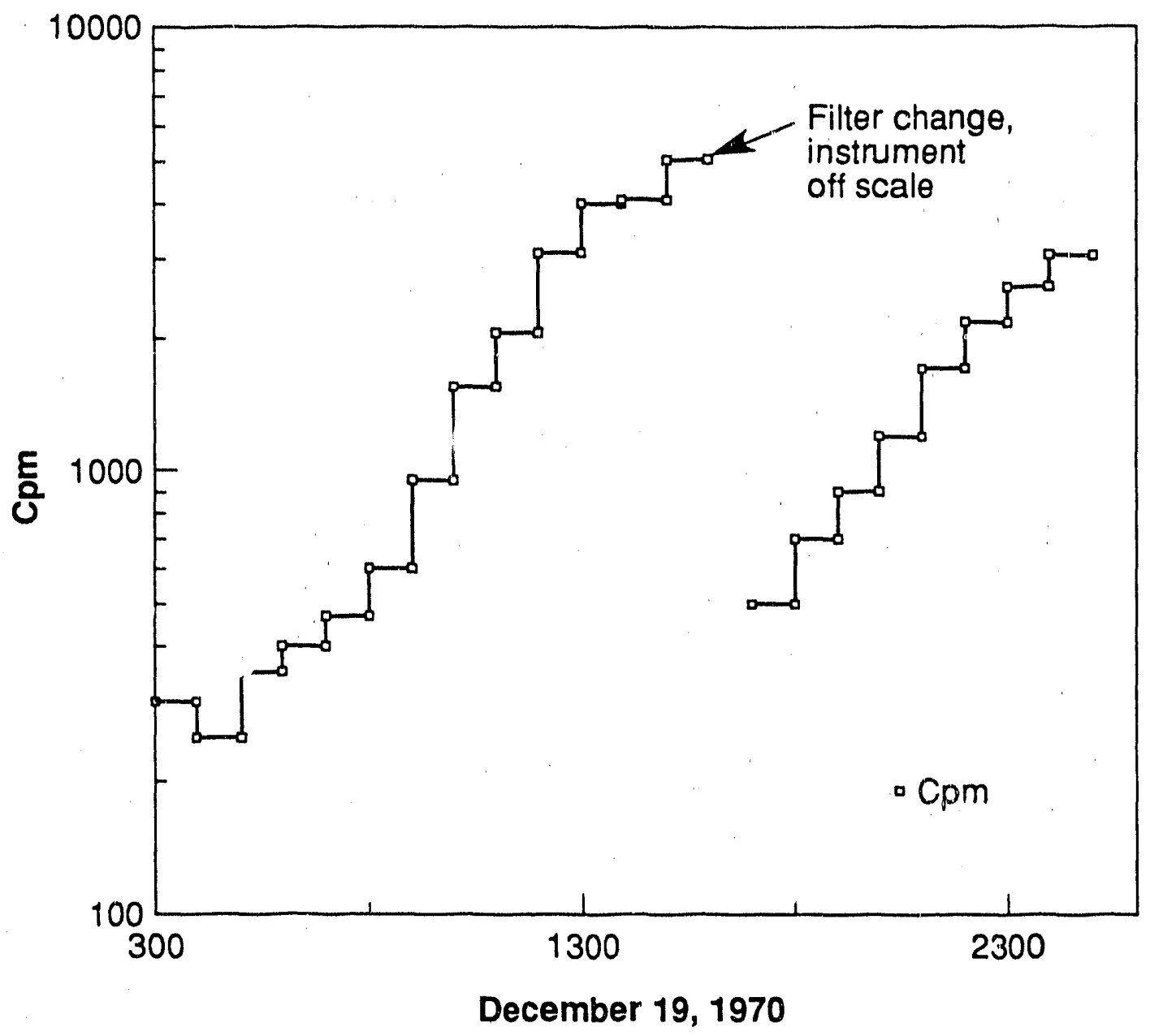

Figure 2. Chart of data from Eberline AIM-3 radiation monitor in Salt Lake City indicating that the arrival time of the BANEBERRY debris cloud was 8:00 to 9:00 a.m. MST December 19, 1970.

instrument at the University of Utah campus was indicating more than 5000 counts per minute, and the filter was changed. Radioactivity in the air continued to rise during the night of December 19th and into December 20th. Filter data obtained with SAS samplers indicated cloud passage or departure late on December 20th.

On the basis of the measurements of radioactivity in the air, on December 20, 1970, University of Utah and LRL personnel began to collect specimens of wild and domestic mammals, vegetation, and snow for radioanalysis at both laboratories. Drs. Pendleton and Koranda went to Manti, Utah, south of Salt Lake City, to obtain samples of a deer herd that had been studied previously by Dr. Pendleton's group. One deer was obtained, and samples of the thyroid glands, rumen, and muscle were taken on that evening. Samples of sagebrush, piñon, juniper, and surface snow were collected by Koranda. Later in the day, Drs. Pendleton and Koranda reviewed 
the situation as described by Pendleton's field crews, who had returned to Salt Lake City. On the basis of this information and data being taken from the monitoring instruments, Pendleton's staff directed their efforts toward collection of animal samples from the northern and central parts of the state.

In this report, we will discuss the air-sampling data and the data obtained from the wild and domestic animals. However, the ultimate objective of the measurements reported here is to determine the radiological hazards to the exposed population from the BANEBERRY event. We will present estimates of the dose to humans from inhalation and from food-chain contamination. We have derived a method to calculate the exposure to a child's thyroid through the cow-milk pathway, the most significant food-chain pathway. We will present our calculations of the dose of radiation from ${ }^{131}$ I to a child's thyroid through the cow-milk pathway, as well as the calculations based on an empirical model derived by others, under actual and hypothetical meteorological conditions.

\section{Air-Filter Analysis}

\section{Air-Sampling Method}

Sequential air samplers (SAS) were fielded by LRL Bio-Medical and University of Utah personnel. The air was sampled by drawing it through an air pump equipped with a fibei glass filter. The air pump was operated in an upright position with a metal deflector above the open filter surface. The deflector prevented rain and snow from directly entering the pump. Manometer readings and a thorough study of the pump characteristics provided data on air-flow rate. We used a convoluted fiberglass filter, MSA (Mine Safety Appliances Co.) 77227 , with an efficiency of $99 \%$ for particles larger than $0.025 \mu \mathrm{m}$ in diameter.

\section{Air Volumes}

All air pumps were field calibrated in the fall of 1970 . Following the BANEBERRY event, the air pumps were typically programmed for $12-\mathrm{h}$ and $24-\mathrm{h}$ sampling periods. Air volumes for the $12-h$ period were approximately $170 \mathrm{~m}^{3}$ and for the $24-\mathrm{h}$ period were approximately $350 \mathrm{~m}^{3}$. The variability in air volumes is mainly a function of air-pump efficiency and altitude. Operational times and corresponding air volumes are presented in Appendix B.

\section{Gamma-Ray Analysis}

The air-filter samples were analyzed for gamma-ray-emitting radionuclides by the use of solid-state, germanium-lithium-drifted detectors. Shortly after the air 
filters were collected from the field-sampling stations, they were compressed and hermetically sealed in thin-walled aluminum cans. The compressed filters occupied the bottom $2 \mathrm{~mm}$ in the cans, and were held in that position by Siyrofoam plugs and the can lids. All gamma-ray spectroscopy was performed with the filters remaining in the aluminum cans. The filters were assayed by placing them on a germanium diode $[\mathrm{Ge}(\mathrm{Li})]$ and counting them for 1000 minutes. Details of these techniques may be found in References 2 and 3. Filter samples from the Eberline AIM-3 air samplers were also sent to LRL by Pendleton for detailed gamma spectroscopy and alpha analysis.

Radionuclides identified and quantified were ${ }^{76} \mathrm{As},{ }^{99} \mathrm{Mo},{ }^{103} \mathrm{Ru},{ }^{122} \mathrm{Sb}, 131 \mathrm{mTe}$, ${ }^{131} \mathrm{I},{ }^{132} \mathrm{Te}, 133 \mathrm{I}$, and ${ }^{133} \mathrm{Xe}$. A portion of the measured ${ }^{133} \mathrm{Xe}$ activity represents decay of the ${ }^{133}$ I since the filter was canned. However, attempts to quantify 133I activity using parent-daughter relationships largely overestimated 133I activity based upon direct measurements of 133I. Apparently, substantial amounts of ${ }^{133}$ Xe were adsorbed on the filter or trapped in particles.

Detectable limits (positive identification) for ${ }^{131} \mathrm{I}$ are somewhat below $10 \mathrm{pCi}$. For typical filters, which sampled approximately $300 \mathrm{~m}^{3}$ of air, this would correspond to detection levels of approximately $0.03 \mathrm{pCi} \mathrm{in}^{-3}$.

A comparison was made between the amount of ${ }^{131}$ I collected on fiberglass and charcoal filters. The results are given in Table 2. LRL employed fiberglass filters for particle collection, while the EPA Southwestern Radiological Health Laboratory (SWRHL) used fiberglass filters backed up with charcoal filters. In both cases, the fiberglass filters had nearly the same efficiencies (LRL used MSA-77277 filters with 99\% for particles larger than $0.025 \mu \mathrm{m}$, and SWRHL used Gelman Type E filters with an efficiency of $98 \%$ for particles larger than $0.05 \mu \mathrm{m}$ ). The apparent loss of ${ }^{131} \mathrm{I}$ from the fiberglass filters can be explained by the work of Heft ${ }^{5}$ who conducted experiments with fallout debris containing ${ }^{131} \mathrm{I}$ in particulate form. In his experiments, air was passed through exposed filters and the gaseous ${ }^{131}$ I collected. Initially, the ${ }^{131}$ I complexed to the particle, but it was lost from the particle as a gas

Table 2. Summary of the data recorded by Southwestern Radiological Health Laboratory on the partitioning of radioiodine between particulate filters (PF) and charcoal cartridges (CC) in Idaho, Montana, and Utah. 4

\begin{tabular}{lccccc}
\hline & \multicolumn{2}{c}{$131_{\mathrm{I}}$} & & \multicolumn{2}{c}{$133_{\mathrm{I}}$} \\
\cline { 2 - 3 } \cline { 5 - 6 } State & $\begin{array}{c}\text { Number of } \\
\text { observations }\end{array}$ & $\begin{array}{c}\text { Ratio } \\
\text { PF/CC }\end{array}$ & & $\begin{array}{c}\text { Number of } \\
\text { observations }\end{array}$ & Ratio \\
\hline Idiaho & 8 & $2.6(1.5-3.6)$ & & 2 & $3.2(3.1-3.4)$ \\
Montana & 3 & $1.6(1.5-1.8)$ & & 0 & - \\
Utah & $\underline{5}$ & $4.6(0.9-9.6)$ & & $\underline{3}$ & $4.7(1.5-8.8)$ \\
$\quad$ Sum or average & 16 & $3.0(0.9-9.6)$ & & 5 & $4.1(1.5-8.8)$ \\
\hline
\end{tabular}


over a period of time. This process is significantly hastened after the particle is entrapped in the filter media because of the increased air flow from the pump compared to normal transport in the atmosphere. The results in Table 2 indicated a mean difference between the particle filters and charcoal filters of a factor of 4.6 (for the State of Utah). This value was used a correction factor for ${ }^{131}$ I dose calculations.

The concentrations of radioactivity in air at each Station for each radionuclide as a function of time are reported in Appendix B. Values represent radioactivity at the time of sampling; they have not been corrected back to time zero. Air concentrations of 131I for Stations 1, 4, and 9 are shown in Fig. 3. It should be noted the horizontal bar represents the time that the air pumps were running and does not represent the arrival time of radioactivity in the case of the first sampling period.

Significant radioactivity was detected at three of five sampling sites for which analysis is complete. The three sampling sites were (1) Station 1 at Draper, approximately 15 miles south of Salt Lake City; (2) Station 4 at Magna, approximately 15 miles west of Salt Lake City; and (3) Station 9 at Snyderville located approximately 20 miles east of Salt Lake City in the Wasatch Range. The debris cloud appeared to pass Stations 1, 4, and 9 in less than 48 hours. This is illustrated in Fig. 3. Very little radioactivity was detected by the air samplers in the southern part of Utah. Station 48 at St. George showed no detectable amounts of radioactivity (see Table B-8). Small arnounts $\left(0.74 \mathrm{pCi} \mathrm{m}^{-3}\right)$ of ${ }^{131}$ I over a period of 24 hours were detected at Cedar City, 50 miles northeast of St. George (see Table B-7).

\section{Iodine-131 Concentrations in Animal Thyroid Glands}

Iodine-131 concentrations in the thyroid glands of foraging animals provide important data about the range and extent of exposure from the BANEBERRY cloud. The thyroid glands of deer, sheep, and jackrabbits, which were collected by Dr. Pendleton and staff during December 19th to 28th, were frozen, analyzed at the University of Utah, and airmailed to Livermore, CA, for further analysis. At LRL, the frozen organs were placed in standard counting vials, weighed, and then preserved by the addition of formalin. The sample vials were then assayed in a dual-channel pulse-height analyzer (PHA) that had one window set to detect gamma rays at $364 \mathrm{keV}$. An organ sample was counted, and the spectrum observed on a 400-channel PHA; the appropriate energy window was set on the dual-channel analyzer in this manner. The deer thyroid glands were also assayed by solid-state gamma spectroscopy. Analysis of the gamma spectra showed only ${ }^{131} \mathrm{I}$.

Iodine-131 concentrations in deer, sheep, and jackrabbit thyroid glands from animals collected in northern Utah from December 20 to 26, 1970, are shown in Table 3. The highest concentration of 131 I was observed in a thyroid from a sheep fetus. Also of interest is the variation in 131I uptake shown in the data on two jackrabbits taken at Faust, Utah, on December 20th. One animal of this pair had no 


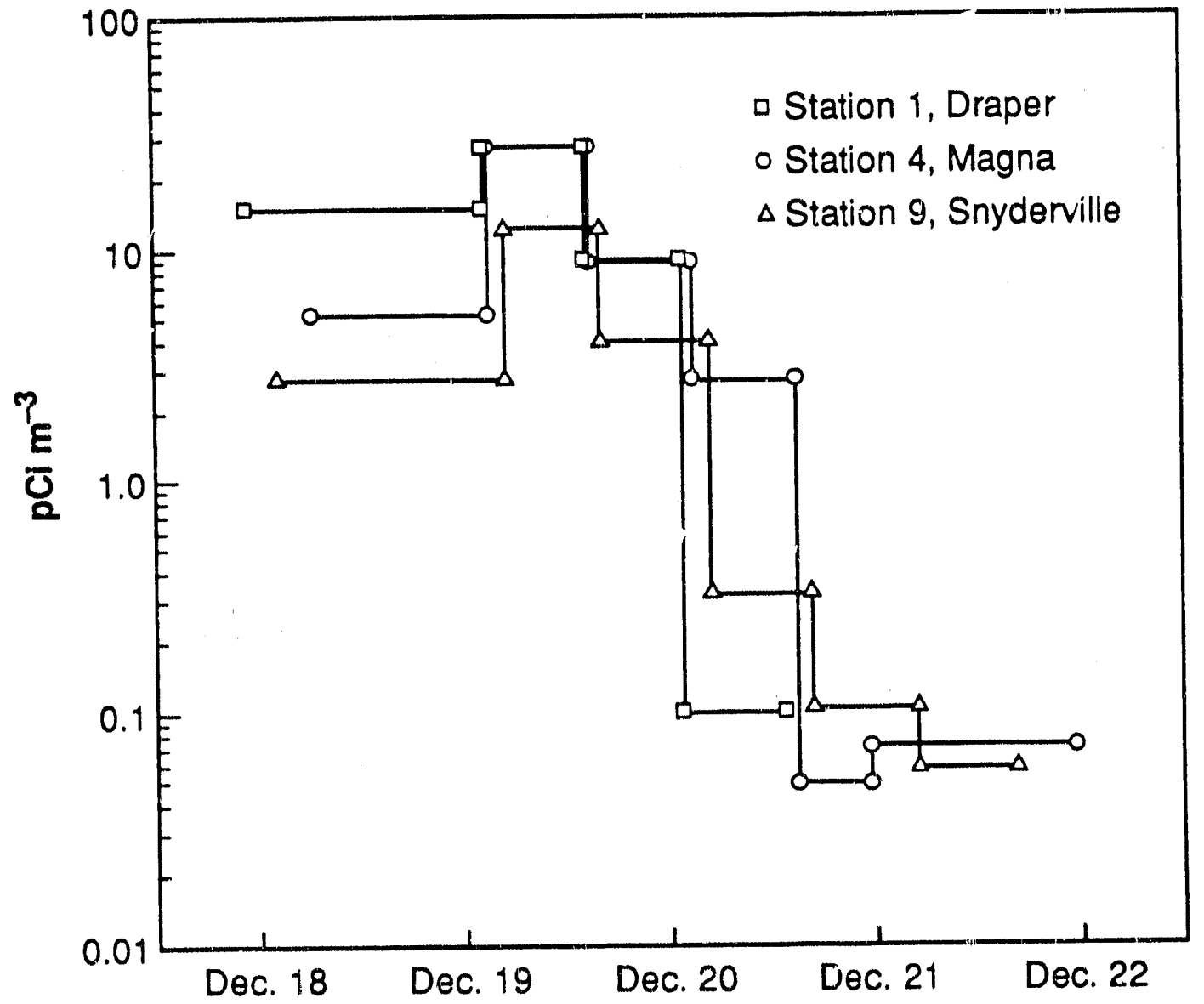

Figure 3. Air concentration of $131 \mathrm{I}$ as a function of time for Station 1, Draper, Utah; Station 4, Magna, Utah; and Statio:9, Snyderville, Utah.

measurable ${ }^{131} \mathrm{I}$ in its thyroid, while the other animal had 29 to $45 \mathrm{pCi} \mathrm{g}^{-1}$ wet wt of thyroid tissues. The geographic range of this early series of mammalian samples embraced the area from 150 miles south of Salt Lake City northward to Grouse Creek, near the Idaho border. Based on the radioactivity measurements made on the air filters, this area was the area of highest recorded radioactivity from the BANEBERRY cloud. These data demonstrate the rapid incorporation of 131 I into the natural food chains in the agricultural environments of Utah subsequent to the BANEBERRY venting. This rapid uptake of ${ }^{131}$ I by wild and domestic herbivores was also demonstrated by Pendleton et al. 6 in previous ecological studies conducted after release of radioactivity at the Nevada Test Site.

The LRL 131I values shown in Table 3 are lower than the University of Utah 131I values. Because the same ${ }^{13 .} \mathrm{Ba}$ and ${ }^{131}$ I standards were analyzed at LRL and the University of Utah, and no significant error was apparent between the analytical systems employed at the two laboratories, the differences in analytical method are not the explanation for the different values. We believe the differences are due to 
Table 3. Sheep, deer, and jackrabbit thyroid gland ${ }^{131}$ I concentrations after the BANEBERRY' event, December 20 to 26, 1970.

\begin{tabular}{|c|c|c|c|c|}
\hline \multirow[b]{2}{*}{ Sample } & \multirow{2}{*}{$\begin{array}{l}\text { Time, date, and } \\
\text { location of sacrifice }\end{array}$} & \multirow[b]{2}{*}{$W t(g)$} & \multicolumn{2}{|c|}{$\begin{array}{l}{ }^{131} \mathrm{I} \mathrm{pCi} \mathrm{g}^{-1} \text { wet wt } \\
\text { at time of capture }\end{array}$} \\
\hline & & & LRL & U. of U. \\
\hline $\begin{array}{l}264-4-21 \text { A-12 } \\
\text { Jackrabbit }\end{array}$ & $\begin{array}{l}\text { 3:30 p.m. } 12 / 20 / 70 \\
\text { Faust, Utah }\end{array}$ & 0.2 & 0 & 0 \\
\hline $\begin{array}{l}264-4-21 B-12 \\
\text { Jackrabbit }\end{array}$ & $\begin{array}{l}3: 30 \text { p.m. } 12 / 20 / 70 \\
\text { Faust, Utah }\end{array}$ & 0.1 & 29 & 45 \\
\hline $\begin{array}{l}\text { 264-33-25-1:2 } \\
\text { Deer, female }\end{array}$ & $\begin{array}{l}4: 20 \text { p.m. } 12 / 20 / 70 \\
\text { Manti, Utah }\end{array}$ & 1.4 & 19 & 35 \\
\hline $\begin{array}{l}264-4-22-12 \\
\text { Sheep, ferrale }\end{array}$ & $\begin{array}{l}\text { 3:30 p.m. } 12 / 21 / 70 \\
\text { Salt Lake City }\end{array}$ & 53 & 6.4 & 10 \\
\hline $\begin{array}{l}264-4-23-12 \\
\text { Sheep, fernale }\end{array}$ & $\begin{array}{l}3: 30 \text { p.m. } 12 / 21 / 70 \\
\text { Salt Lake City }\end{array}$ & 3.8 & 10 & 20 \\
\hline $\begin{array}{l}264-4-23-00 \\
\text { Sheep fetus } \\
\text { (of 23-12) }\end{array}$ & $\begin{array}{l}3: 30 \text { p.m. } 12 / 21 / 70 \\
\text { Salt Lake City }\end{array}$ & 0.8 & 23 & 100 \\
\hline $\begin{array}{l}264-4-24-12 \\
\text { Sheep, female }\end{array}$ & $\begin{array}{l}3: 30 \text { p.m. } 12 / 21 / 70 \\
\text { Salt Lake Ciiy }\end{array}$ & 7.0 & 2.6 & 7 \\
\hline $\begin{array}{l}\text { 264-1-21-12 } \\
\text { Deer, female }\end{array}$ & $\begin{array}{l}\text { 5:00 p.m. } 12 / 21 / 70 \\
\text { Provo, Utah }\end{array}$ & 3.0 & 14 & 21 \\
\hline $\begin{array}{l}264-80-23-12 \\
\text { Sheep, female }\end{array}$ & $\begin{array}{l}2: 30 \text { p.m. } 12 / 25 / 70 \\
\text { Grouse Creek, Utah }\end{array}$ & 5.7 & 28 & 66 \\
\hline $\begin{array}{l}264-80-24-12 \\
\text { Sheep, female }\end{array}$ & $\begin{array}{l}11: 00 \text { p.m. } 12 / 25 / 70 \\
\text { Grouse Creek, Utah }\end{array}$ & 9.9 & 26 & 56 \\
\hline $\begin{array}{l}264-4-31-12 \\
\text { Sheep, female }\end{array}$ & $\begin{array}{l}\text { 4:00 p.m. } 12 / 26 / 70 \\
\text { Salt Lake City }\end{array}$ & 3.0 & 32 & 70 \\
\hline $\begin{array}{l}264-4-32-12 \\
\text { Sheep, female }\end{array}$ & $\begin{array}{l}4: 00 \text { p.m. } 12 / 25 / 70 \\
\text { Salt Lake City }\end{array}$ & 11.6 & 12 & 25 \\
\hline
\end{tabular}

loss of sample. The thyroid samples in question were counted first at the University of Utah and then shipped to LRL. The organs were not hard frozen when received at LRL and some autolysis had taken place. When the samples were transferred to the special counting vials used at LRL, as much as $1 \mathrm{~mL}$ of fluid from some of the samples was lost. This is the only apparent reason for the differences in ${ }^{131}$ I concentrations determined by the two laboratories. To verify this explanation, the glass vials from the University oi Utah were crushed and placed in LRL counting vials; ${ }^{131}$ I was detected. For this reason, the University of Utah data are to be regarded as the best analyses of these samples.

Seven deer and four sheep were also collected in northern Utah from December 22 to 29,1970 . The thyroid glands from these animals were received at 
LRL on January 7, 1971, and assayed in the same manner as the preceding series of samples. The results of these analyses are shown in Table 4. These data demonstrate a continuing buildup of 131 I in the thyroid glands of these animals due to the ingestion of contaminated forage. Deer had higher concentrations of ${ }^{131_{1}}$ in their thyroids than sheep because the natural vegetation was contaminated, whereas stored forage was not extensively exposed to radioactive fallout. Of additional interest was the greater 131 I uptake measured in thyroid glands of young deer as compared with that measured in adult deer. The two young deer, both females with small thyroids (264-6-5-12 and 264-6-6-12), had the highest ${ }^{131}$ I concentrations in this series of samples. The thyroid gland of an older male deer (264-6-9-12, $4 \mathrm{pt}$.) had one-half the 131I activity of the smaller thyroid gland of a younger male deer (264-6-10-12) taken at the same locality. In preparing this second series of thyroid glands for radioanalysis, each original sample vial was rinsed with 2 to $4 \mathrm{~mL} \mathrm{KOH}$

Table 4. Deer and sheep thyroid gland 131I concentrations after the BANEBERRY event, December 22 to $29,1970$.

\begin{tabular}{|c|c|c|c|c|}
\hline \multirow[b]{2}{*}{ Sample } & \multirow{2}{*}{$\begin{array}{l}\text { Time, date, and } \\
\text { location of sacrifice }\end{array}$} & \multirow{2}{*}{$\begin{array}{l}\text { Thyroid } \\
\text { wet wt (g) }\end{array}$} & \multicolumn{2}{|c|}{${ }^{131} \mathrm{I} \mathrm{pCi}^{-1}$ wet wt } \\
\hline & & & LRL & U. of U. \\
\hline $\begin{array}{l}\text { 264-1-24-12 } \\
\text { Deer, female }\end{array}$ & $\begin{array}{l}7: 30 \text { p.m. } 12 / 22 / 70 \\
\text { Salt Lake City vicinity }\end{array}$ & 5.2 & 760 & $850^{\mathrm{a}}$ \\
\hline $\begin{array}{l}264-1-30-12 \\
\text { Deer }\end{array}$ & $\begin{array}{l}6: 00 \text { p.m. } 12 / 23 / 70 \\
\text { Salt Lake City vicinity }\end{array}$ & 5.7 & 580 & 620 \\
\hline $\begin{array}{l}264-6-7-12 \\
\text { Deer, roadkill }\end{array}$ & $\begin{array}{l}\text { 6:00 p.m. } 12 / 26 / 70 \\
\text { Farmington, Utah }\end{array}$ & 2.7 & 220 & 310 \\
\hline $\begin{array}{l}264-6-9-12 \\
\text { Deer, male, } 4 \text { pt. }\end{array}$ & $\begin{array}{l}\text { 10:00 p.m. } 12 / 28 / 70 \\
\text { Ogden, Utah }\end{array}$ & 8.4 & 210 & 220 \\
\hline $\begin{array}{l}264-6-10-12 \\
\text { Deer, male, } 2 \text { pt. }\end{array}$ & $\begin{array}{l}\text { 10:00 p.m. } 12 / 28 / 70 \\
\text { Ogden, Utah }\end{array}$ & 5.2 & 420 & 450 \\
\hline $\begin{array}{l}264-6-5-12 \\
\text { Deer, female }\end{array}$ & $\begin{array}{l}9: 00 \text { a.m. } 12 / 28 / 70 \\
\text { Farmington, Utah }\end{array}$ & 1.2 & 750 & 1100 \\
\hline $\begin{array}{l}264-6-6-12 \\
\text { Deer, female }\end{array}$ & $\begin{array}{l}\text { 9:00 a.m. } 12 / 28 / 70 \\
\text { Farmington, Utah }\end{array}$ & 1.2 & 1600 & 2300 \\
\hline $\begin{array}{l}264-68-36-12 \\
\text { Sheep, female }\end{array}$ & $\begin{array}{l}\text { 6:15 p.m. 12/28/70 } \\
\text { Bluebell, Utah }\end{array}$ & 7.7 & 8 & 6 \\
\hline $\begin{array}{l}264-68-37-12 \\
\text { Sheep, female }\end{array}$ & $\begin{array}{l}\text { 6:15 p.m. } 12 / 28 / 70 \\
\text { Bluebell, Utah }\end{array}$ & 4.45 & 15 & 22 \\
\hline $\begin{array}{l}264-68-38-12 \\
\text { Sheep, female }\end{array}$ & $\begin{array}{l}\text { 6:15 p.m. } 12 / 28 / 70 \\
\text { Bluebell, Utah }\end{array}$ & 6.4 & 18 & 24 \\
\hline $\begin{array}{l}264-1-31-12 \\
\text { Sheep, female }\end{array}$ & $\begin{array}{l}\text { 6:00 p.m. } 12 / 29 / 70 \\
\text { Draper, Utah }\end{array}$ & 5.5 & 26 & 27 \\
\hline
\end{tabular}


and this residue was added to the LRL counting vial. As a consequence, the LRL and University of Utah analyses for this series showed better agreement.

\section{Analysis of Snow Samples}

Snow samples were collected at five stations in Utah on December 30 to 31, 1970. The dimensions of the snow samples and the locations where these samples were collected are given in Table 5. We placed 4-mL aliquots of these samples in lowbackground plastic vials for liquid-scintillation counting. No detectable tritium was observed in this series of samples. The samples were assayed at the University of Utah for gamma-emitting radionuclides.

Table 5. Tritium content of snow samples collected in Utah, December 30-31, 1970.

\begin{tabular}{|c|c|c|c|}
\hline $\begin{array}{l}\text { Sample } \\
\text { number }\end{array}$ & $\begin{array}{c}\text { Volume } \\
\text { (area and depth) }\end{array}$ & Station & $\begin{array}{c}\text { Tritium } \\
\text { concentration }\end{array}$ \\
\hline $\begin{array}{r}264-1-32 A \\
-32 B \\
-32 C\end{array}$ & $\begin{array}{l}1.5 \mathrm{~m}^{2} \\
5 \mathrm{~cm} \text { deep }\end{array}$ & $\begin{array}{c}\text { Station } 1 \\
\text { Draper, Utah } 12 / 30 / 70\end{array}$ & $\begin{array}{l}\text { NDa } \\
\text { ND } \\
\text { ND }\end{array}$ \\
\hline $\begin{array}{l}-33 A \\
-33 B \\
-33 C\end{array}$ & $\begin{array}{l}0.2 \mathrm{~m}^{2} \\
30 \mathrm{~cm} \text { deep }\end{array}$ & $\begin{array}{c}\text { Station } 1 \\
\text { Draper, Utah } 12 / 30 / 70\end{array}$ & $\begin{array}{l}\text { ND } \\
\text { ND } \\
\text { ND }\end{array}$ \\
\hline $\begin{array}{r}264-4-38 \mathrm{~A} \\
-38 \mathrm{~B} \\
-38 \mathrm{C}\end{array}$ & $\begin{array}{l}2 \mathrm{~m}^{2} \\
5 \mathrm{~cm} \text { deep }\end{array}$ & $\begin{array}{c}\text { Station } 4 \\
\text { Magna, Utah } 12 / 30 / 70\end{array}$ & $\begin{array}{l}\text { ND } \\
\text { ND } \\
\text { ND }\end{array}$ \\
\hline $\begin{array}{l}-39 A \\
-39 B \\
-39 C\end{array}$ & $\begin{array}{l}0.8 \mathrm{~m}^{2} \\
13 \mathrm{~cm} \text { deep }\end{array}$ & $\begin{array}{c}\text { Station } 4 \\
\text { Magna, Utah } 12 / 30 / 70\end{array}$ & $\begin{array}{l}\text { ND } \\
\text { ND } \\
\text { ND }\end{array}$ \\
\hline $\begin{array}{r}264-9-31 \mathrm{~A} \\
-31 \mathrm{~B} \\
-31 \mathrm{C}\end{array}$ & $\begin{array}{l}1.5 \mathrm{~m}^{2} \\
5 \mathrm{~cm} \text { deep }\end{array}$ & $\begin{array}{c}\text { Station } 9 \\
\text { Snyderville, Utah } 12 / 30 / 70\end{array}$ & $\begin{array}{l}\text { ND } \\
\text { ND } \\
\text { ND }\end{array}$ \\
\hline $\begin{array}{l}-32 A \\
-32 B\end{array}$ & $\begin{array}{l}0.2 \mathrm{~m}^{2} \\
38 \mathrm{~cm} \text { deep }\end{array}$ & $\begin{array}{c}\text { Station } 9 \\
\text { Snyderville, Utah } 12 / 30 / 70\end{array}$ & $\begin{array}{l}\text { ND } \\
\text { ND }\end{array}$ \\
\hline $\begin{array}{r}264-71-22 A \\
-22 B\end{array}$ & $\begin{array}{l}0.4 \mathrm{~m}^{2} \\
15 \mathrm{~cm} \text { deep }\end{array}$ & $\begin{array}{c}\text { Station } 71 \\
\text { Cornish, Utah } 12 / 31 / 70\end{array}$ & $\begin{array}{l}\text { ND } \\
\text { ND }\end{array}$ \\
\hline $\begin{array}{r}264-78-26 A \\
-26 B \\
-26 C\end{array}$ & $\begin{array}{l}1 \mathrm{~m}^{2} \\
5 \mathrm{~cm} \text { deep }\end{array}$ & $\begin{array}{c}\text { Station } 78 \\
\text { Logan, Utah } 12 / 31 / 70\end{array}$ & $\begin{array}{l}\text { ND } \\
\text { ND } \\
\text { ND }\end{array}$ \\
\hline $\begin{array}{l}-27 \mathrm{~A} \\
-27 \mathrm{~B}\end{array}$ & $\begin{array}{l}0.3 \mathrm{~m}^{2} \\
18 \mathrm{~cm} \text { deep }\end{array}$ & $\begin{array}{c}\text { Station } 78 \\
\text { Logan, Utah } 12 / 31 / 70\end{array}$ & $\begin{array}{l}\text { ND } \\
\text { ND }\end{array}$ \\
\hline
\end{tabular}




\section{Evaluation of Radiological Hazards}

The ultimate purpose for the measurements reported here, and for additional measurements made by the University of Utah, ${ }^{1}$ is to enable the determination of the radiological hazards to the exposed population. Fortunately, a record snowfall preceded the BANEBERRY venting, and the actual exposure was minimized. In this report, we will evaluate the inhalation and submersion dose and the dose from food-chain coniamination. We will limit our examination of food-chain contamination to the cow-milk pathway; we will consider both the exposures that probably occurred and those that could have occurred for such an accidental venting during a time of year when dairy cows were grazing on pasture or fed using greenchop methods. We will present dose estimates based on air-filter data for the hypothetical situations and based on measurements of hay and milk contamination as well as air-filter data for the actual event.

\section{Inhalation and Submersion Dose}

Table 6 summarizes the integrated air activity of 131I recorded by the 15 sequential-air-sampling stations in Utah. These data have been corrected using data derived from EPA measurements (Table 2) for the additional fraction of gaseous ${ }^{131}$ I that probably was not trapped by the particulate filters. The data in Table 6 indicate that the highest exposures were recorded in the Salt Lake City area (Station 1, Draper; Station 4, Magna; and Station 9, Snyderville), with relatively high exposures also recorded in the Cornish, Logan, Grouse Creek, and Wendover areas (Stations $71,78,80 \mathrm{~A}$, and 90 ). These data are fairly consistent with those reported by EPA, ${ }^{4}$ except the EPA's highest recorded exposure $\left(830 \mathrm{pCi} \mathrm{h} \mathrm{m}^{-3}\right)$ was at Garrison, a location that was not sampled by this program. The highest exposure recorded by the LRL/University of Utah program was at Station 1. Because this location is also close to the major population center of the state, the data recorded at this station will be used to make inhalation dose estimates.

Values of the integrated air activities for all radionuclides measured at Station 1 are shown in Table 7 (131 I and 133I have been corrected for their gaseous component using data from Table 2). The general analyses of $\mathrm{Ng}$ and Thompson ${ }^{7}$ and $\mathrm{Ng}$ and Tewes ${ }^{8}$ for the release of activity from nuclear detonations have identified the additional radionuclides ${ }^{3} \mathrm{H},{ }^{89} \mathrm{Sr},{ }^{90} \mathrm{Sr},{ }^{136} \mathrm{Cs}$, and ${ }^{137} \mathrm{Cs}$ as possible major contributors to the total hazard. The integrated air activities of these radionuclides, which were not measured, were therefore estimated. The ${ }^{3} \mathrm{H}$ was estimated on the basis of the ${ }^{3} \mathrm{H} /{ }^{131} \mathrm{I}$ ratio observed in the cioud by EPA. ${ }^{9}$ We estimated the ${ }^{89} \mathrm{Sr},{ }^{90} \mathrm{Sr}$, ${ }^{136} \mathrm{Cs}$, and ${ }^{137} \mathrm{Cs}$ values on the basis of their expected production and fractional release in comparison to ${ }^{131} \mathrm{I} .10$ The results of these estimates are shown in Table 7, where the values for all radionuclides are also compared to the Atomic Energy Commission (AEC) Concentration Guidance (CG) for continuous exposure of a pcpulation in an uncontrolled area. ${ }^{11}$ 
Table 6. Integrated ${ }^{131}$ I air activity measured in Utah; these data have been corrected for contribution due to gaseous 131I using data from Table 2. Measurements by EPA ${ }^{4}$ at nearby stations are also given.

\begin{tabular}{llcc}
\hline & & \multicolumn{2}{c}{ Integrated 131 I air activity } \\
\cline { 3 - 4 } Station & & $\begin{array}{c}\text { LRL/U. of U. } \\
\left(\mathrm{pCi} \mathrm{h} \mathrm{m}^{-3}\right)\end{array}$ & $\begin{array}{c}\text { EPA } \\
\left(\mathrm{pCi} \mathrm{h} \mathrm{m}^{-3}\right)\end{array}$ \\
\hline 1 & Draper & 1100 & 390 \\
4 & Magna & 810 & \\
9 & Snyderville & 320 & \\
33 & Ephraim & 21 & 8.3 \\
40 & Monroe & 23 & $\mathrm{ND}$ \\
45 & Cedar City & 23 & 19 \\
48 & St. George & ND & \\
49 & Milford & 28 & 330 \\
57 & Bridgeland & 0.51 & \\
61 & Delta & 17 & 220 \\
68 & Bluebell & 32 & \\
71 & Cornish & 360 & \\
78 & Logan & 230 & \\
$80 \mathrm{~A}$ & Grouse Creek & 200 & \\
90 & Wendover & 370 & \\
\hline
\end{tabular}

a ND stands for not detected.

The AEC standards were developed from primary standards of maximum allowable dose per year, so the CG values given in Table 7 are in terms of allowable integrated air activities ( $\mathrm{pCi} \mathrm{h} \mathrm{m}{ }^{-3}$ ) over a one-year period. Assuming that no significant radionuclides have been omitted from the tabulation, the sum in Table 7 indicates that the maximum recorded exposure (at Station 1) was 1\% of that allowable by the CG standards.

The estimated doses received through inhalation or submersion for each radionuclide are given in Table 8 . These estimates were derived by multiplying the individual fractional CG values by the primary dose standards from which the CG values were derived ( $0.17 \mathrm{rad}$ to whole body, gonads, or bone marrow; $0.5 \mathrm{rad}$ to other organs). This is a conservative estimate because the exposure was transitory, not continuous (and therefore assumes instantaneous equilibration). Results in Table 8 indicate that by far the largest potential dose was received by the thyroid, $0.005 \mathrm{rad}$.

\section{Dose from Food-Chain Contamination}

An evaluation of potential radiological hazards from this vent must, however, take into consideration means of exposure in addition to inhalation and submersion. In particular, the internal dose as a result of food-chain contamination should be considered. This has been attempted for the cow-milk pathway, which is 
Table 7. Comparison of integrated air activity at Utah Station 1 to AEC Concentration Guidance for continuous exposure ${ }^{a}$ integrated over one year.

\begin{tabular}{|c|c|c|c|}
\hline Nuclide & $\begin{array}{c}\text { Concentration } \\
\text { Guidance } \\
\left.(\mathrm{pCi} \mathrm{h} \mathrm{m})^{-3}\right)\end{array}$ & $\begin{array}{c}\text { Integrated } \\
\text { activity } \\
(\mathrm{pCi} \mathrm{h} \mathrm{m-3)}\end{array}$ & $\begin{array}{c}\text { Fraction of } \\
\text { Concentration } \\
\text { Guidance }\end{array}$ \\
\hline${ }^{3} \mathrm{H}^{\mathrm{b}}$ & $6 \times 10^{8}$ & $1.4 \times 10^{3}$ & $2.3 \times 10^{-6}$ \\
\hline${ }^{76} \mathrm{As}$ & $9 \times 10^{6}$ & $1.5 \times 10^{3}$ & $1.7 \times 10^{-4}$ \\
\hline${ }^{89} \mathrm{Sr}^{\mathrm{C}}$ & $9 \times 10^{5}$ & $1.2 \times 10^{2}$ & $1.3 \times 10^{-4}$ \\
\hline${ }^{90} \mathrm{Sr}^{\mathrm{c}}$ & $9 \times 10^{4}$ & $4.7 \times 10^{-2}$ & $5.2 \times 10^{-7}$ \\
\hline${ }^{99} \mathrm{Mo}$ & $3 \times 10^{7}$ & $7.9 \times 10^{2}$ & $2.6 \times 10^{-5}$ \\
\hline${ }^{103} \mathrm{Ru}$ & $9 \times 10^{6}$ & $1.6 \times 10^{2}$ & $1.6 \times 10^{-5}$ \\
\hline${ }^{122} \mathrm{Sb}$ & $2 \times 10^{7}$ & $6.6 \times 10^{2}$ & $3.3 \times 10^{-5}$ \\
\hline $131 \mathrm{~m} \mathrm{Te}$ & $2 \times 10^{7}$ & $1.3 \times 10^{3}$ & $6.5 \times 10^{-5}$ \\
\hline${ }^{131} I^{d}$ & $3 \times 10^{5}$ & $1.1 \times 10^{3}$ & $3.7 \times 10^{-3}$ \\
\hline${ }^{132} \mathrm{Te}$ & $1 \times 10^{7}$ & $2.9 \times 10^{3}$ & $2.9 \times 10^{-4}$ \\
\hline $133 \mathrm{I}^{\mathrm{d}}$ & $1 \times 10^{6}$ & $6.5 \times 10^{3}$ & $6.5 \times 10^{-3}$ \\
\hline${ }^{133} \times \mathrm{e}^{\mathrm{e}}$ & $9 \times 10^{8}$ & $2.5 \times 10^{3}$ & $2.8 \times 10^{-6}$ \\
\hline${ }^{136} \mathrm{Cs}^{\mathrm{c}}$ & $2 \times 10^{7}$ & $4.0 \times 10^{1}$ & $2.0 \times 10^{-6}$ \\
\hline${ }^{137} \operatorname{Cs}^{c}$ & $2 \times 10^{6}$ & $1.1 \times 10^{0}$ & $5.5 \times 10^{-7}$ \\
\hline Sum & & & $1.1 \times 10^{-2}$ \\
\hline
\end{tabular}

a Concentration Guidance from Chapter 0524, USAEC Manual, 11 based upon an average dose to a suitable sample of an exposed population in an uncontrolled area.

$b$ Estimated from $3 \mathrm{H} / 131$ I ratio in cloud as measured by SWHRL.

c Estimated from expected production and assumed fractional release in comparison to ${ }^{131} \mathrm{I}$.

d Corrected for gaseous component (Table 2).

e Xenon-133 in the free gaseous state would not be efficiently trapped by the filter used. Much of the measured 133 Xe activity represents decay of ${ }^{133}$ I since the filter was sealed.

presumably the most critical pathway. 7,8 Our analysis will first address the question of what might have happened if the venting had occurred during a time when dairy cows were on fresh feed, and then address the actual exposures, which are based on our calculations from air-filter data as well as on measurements of activity found in stored feed and milk. ${ }^{1}$ In all cases, we will analyze the dose for a child, because such results will be more conservative than an analysis for an adult.

\section{Dose Estimate When Dairy Cows Consume Fresh Feed or Green Chop}

The first consideration in assessing what might have happened during a time when dairy cows were on fresh feed or green chop is whether meteorological conditions would have produced the same levels of ground-level air activity as were actually produced. This question has been examir ed by Peterson and Crawford, 13 who think that the air activities would probably be between factors of 2 to 3 times higher or lower depending upon specific conditions, although they have not made detailed calculations. The assumption will be made here that the air activities would have been the same as those actually measured for the winter venting. Again, we use the values from Station 1 for integrated air activity because 
Table 8. Estimated dose ${ }^{a}$ from inhalation or submersion at Station 1, Draper, Utah.

\begin{tabular}{ccc}
\hline Nuclide & Dose (rad) & Critical organ \\
\hline${ }^{3} \mathrm{H}$ & $3.9 \times 10^{-7}$ & Body tissue \\
${ }^{76} \mathrm{As}$ & $8.5 \times 10^{-5}$ & GI tract \\
${ }^{89} \mathrm{Sr}$ & $6.5 \times 10^{-5}$ & Bone \\
${ }^{90} \mathrm{Sr}$ & $2.6 \times 10^{-7}$ & Bone \\
${ }^{99} \mathrm{Mo}$ & $1.3 \times 10^{-5}$ & GI tract \\
${ }^{103} \mathrm{Ru}$ & $8.0 \times 10^{-6}$ & Lung \\
$122 \mathrm{Sb}$ & $1.7 \times 10^{-5}$ & GI tract \\
${ }^{131 \mathrm{~m} \mathrm{Te}}$ & $3.2 \times 10^{-5}$ & GI tract \\
$131_{\mathrm{I}}$ & $1.8 \times 10^{-3}$ & Thyroid \\
$132 \mathrm{Te}$ & $1.4 \times 10^{-4}$ & GI tract \\
$133 \mathrm{I}$ & $3.2 \times 10^{-3}$ & Thyroid \\
$133 \mathrm{Xe}$ & $4.8 \times 10^{-7}$ & Total body \\
$136 \mathrm{Cs}$ & $1.0 \times 10^{-6}$ & Lung \\
$137 \mathrm{Cs}$ & $2.8 \times 10^{-7}$ & Lung \\
\hline
\end{tabular}

a Obtained by multiplying $0.17 \mathrm{rad}$ (total body or body tissue) or $0.5 \mathrm{rad}$ (other organs) by the fraction of Concentration Guidance from Table 7.

b From Reference 12.

they were the highest measured values and were taken close to the major population center.

Dry Deposition. The integrated air activity values in Table 7 were multiplied by a deposition velocity of $40 \mathrm{~m} \mathrm{~h}^{-1}$ to estimate forage contamination by dry deposition. 8 Estimates of maximum dosage through the forage-cow-milk pathway may then be obtained by dividing these results by the unit-rad deposition value, $F_{1}$ (the level of ground contamination in $\mu \mathrm{Ci} \mathrm{m} \mathrm{m}^{-2}$ that will result in a dose of $1 \mathrm{rad}$ to the target organ). $F_{1}$ values for a child's whole body, bone, and GI tract were taken from $\mathrm{Ng}$ et al. 14 Values for a child's thyroid are not given in Ref. 14, and the following model was used to calculate such $F_{1}$ values. Before undertaking specific calculations, we present the complete general model, which can be used to calculate dose estimates from a variety of actual measurements, including integrated air activity, forage contamination, or milk concentration.

Initial forage activity is determined by

$$
\begin{array}{ll}
A_{0}=V_{\mathrm{g}}(I A C) & \text { and } \\
C_{0} & =\frac{V_{\mathrm{g}}}{D}(I A C)
\end{array}
$$

where

$$
\begin{aligned}
A_{\mathrm{o}} & =\text { Forage contamination, } \mu \mathrm{Ci} \mathrm{m}-2 \\
V_{\mathrm{g}} & =\text { Deposition velocity, } \mathrm{m} \mathrm{h}^{-1} \\
(I A C) & =\text { Integrated air activity, } \mu \mathrm{Ci} \mathrm{h} \mathrm{m}^{-3}
\end{aligned}
$$


$C_{0}=$ Forage contamination, $\mu \mathrm{Ci} \mathrm{kg}^{-1}$,

$D=$ Forage density, $\mathrm{kg} \mathrm{m}^{-2}$.

Dairy cows' initial intake is given by

$$
I_{0}=(U A F) A_{0}=(M P D) C_{0},
$$

where

$I_{0}=D_{\text {iry cow's initial intake, } \mu \mathrm{Ci} \mathrm{d}^{-1},}$

$(U A F)=$ Utilized area factor, $\mathrm{m}^{2} \mathrm{~d}^{-1}$,

$(M P D)=$ Mass per day, $\mathrm{kg} \mathrm{d}^{-1}$.

Dairy cow's intake as a function of time is given by

$$
I=I_{0} \mathrm{e}^{-\left(\lambda+\lambda_{\mathrm{p}}\right) t}
$$

where

$I=$ Dairy cow's intake, $\mu \mathrm{Ci} \mathrm{d}^{-1}$,

$\lambda=$ Radioactive decay constant, $\mathrm{d}^{-1}$,

$\lambda_{\mathrm{p}}=$ Physical loss from forage constant, $\mathrm{d}^{-1}$,

$t=$ Time following contamination, $\mathrm{d}$.

Concentration in milk is given by

$$
\begin{aligned}
\frac{\mathrm{d} C_{\mathrm{m}}}{\mathrm{dt}} & =f_{\mathrm{m}} I-\left(\lambda+\lambda_{\mathrm{m}}\right) C_{\mathrm{m}}, \quad \text { and } \\
C_{\mathrm{m}} & =\frac{f_{\mathrm{m}} I_{\mathrm{o}}}{\lambda_{\mathrm{m}}-\lambda_{\mathrm{p}}}\left[\mathrm{e}^{-\left(\lambda+\lambda_{\mathrm{p}}\right) t}-\mathrm{e}^{-\left(\lambda+\lambda_{\mathrm{m}}\right) t}\right],
\end{aligned}
$$

where

$C_{\mathrm{m}}=$ Activity in milk, $\mu \mathrm{Ci} \mathrm{L} \mathrm{L}^{-1}$,

$f_{\mathrm{m}}=$ Fraction of daily intake secreted per liter of milk per day, $\mathrm{L}^{-1}$,

$\lambda_{\mathrm{m}}=$ Biological elimination rate from milk, $\mathrm{d}^{-1}$.

Concentration in a child's thyroid is determined by

$$
\begin{aligned}
\frac{\mathrm{d} C_{t}}{\mathrm{dt}}= & \frac{f_{\mathrm{w}} L_{\mathrm{m}} C_{\mathrm{m}}}{M}-\left(\lambda+\lambda_{\mathrm{t}}\right) C_{\mathrm{t}} \quad \text { and } \\
C_{\mathrm{t}}= & \frac{f_{\mathrm{m}} f_{\mathrm{w}} L_{\mathrm{m}}{ }^{\prime} \mathrm{O}}{M\left(\lambda_{\mathrm{m}}-\lambda_{\mathrm{p}}\right)\left(\lambda_{\mathrm{t}}-\lambda_{\mathrm{p}}\right)\left(\lambda_{\mathrm{t}}-\lambda_{\mathrm{m}}\right)} \\
& \times\left[\left(\lambda_{\mathrm{t}}-\lambda_{\mathrm{m}}\right) \mathrm{e}^{-\left(\lambda+\lambda_{\mathrm{p}}\right) t}-\left(\lambda_{\mathrm{t}}-\lambda_{\mathrm{p}}\right) \mathrm{e}^{-\left(\lambda+\lambda_{\mathrm{m}}\right) t}+\left(\lambda_{\mathrm{m}}-\lambda_{\mathrm{p}}\right) \mathrm{e}^{-\left(\lambda+\lambda_{\mathrm{t}}\right) t}\right],
\end{aligned}
$$

where

$C_{\mathrm{t}}=$ Activity in thyroid, $\mu \mathrm{Ci} \mathrm{g}^{-1}$,

$f_{w}=$ Fraction of iodine ingested reaching thyroid,

$L_{\mathrm{m}}=$ Daily milk consumption, $\mathrm{L} \mathrm{d}^{-1}$,

$M=$ Thyroid mass, $\mathrm{g}$,

$\lambda_{t}=$ Biological elimination rate from thyroid, $d^{-1}$. 
Integrated thyroid dose is determined from

$$
\begin{aligned}
& D_{t}=51 E \int_{0}^{\infty} C_{t} d t \quad \text { and } \\
& D_{t}=\frac{51 E f_{m} f_{w} L_{m} I_{0}}{M\left(\lambda+\lambda_{t}\right)\left(\lambda+\lambda_{m}\right)\left(\lambda+\lambda_{p}\right)}
\end{aligned}
$$

where

$D_{\mathrm{t}}=$ Thyroid dose, rad,

$51=$ Dose-conversion constant, $\operatorname{rad} g$ dis $\mu \mathrm{Ci}^{-1} \mathrm{MeV}^{-1} \mathrm{~d}^{-1}$,

$E=$ Effective energy, $\mathrm{MeV} \mathrm{dis}^{-1}$.

Unit-rad deposition is calculated from

$$
\begin{aligned}
& F_{1} \equiv A_{0}, \text { when } D_{t}=1 \mathrm{rad}, \quad \text { and } \\
& \ddot{r}_{1}=\frac{M\left(\lambda+\lambda_{t}\right)\left(\lambda+\lambda_{m}\right)\left(\lambda+\dot{\lambda}_{p}\right)}{51 E f_{m} f_{w} L_{m}(\text { UAF })},
\end{aligned}
$$

where

$$
F_{1}=\text { Unit-rad deposition, } \mu \mathrm{Ci} \mathrm{m}^{-2} \mathrm{rad}^{-1} \text {. }
$$

A complete assessment of the thyroid exposure requires that the contribution from the radionuclides $131 \mathrm{~m} \mathrm{Te}$ (which decays to ${ }^{131} \mathrm{I}$ ) and ${ }^{132} \mathrm{Te}$ (which decays to ${ }^{132} \mathrm{I}$ ) also be considered. The following equations are generally appropriate for such parent-daughter radioactivity cases, provided that the parent radioactivity is much less biologically available than the daughter activity.

Dairy cow's intake of daughter activity is given by

$$
\begin{aligned}
\frac{\mathrm{d} N_{2}}{\mathrm{dt}} & =\lambda_{1} N_{1}^{\mathrm{O}} \mathrm{e}^{-\left(\lambda_{1}+\lambda_{\mathrm{p}}\right) t}-\left(\lambda_{2}+\lambda_{\mathrm{p}}\right) N_{2} \\
I & =\frac{\lambda_{2} I_{1}^{\mathrm{O}}}{\left(\lambda_{2}-\lambda_{1}\right)}\left[\mathrm{e}^{-\left(\lambda_{1}+\lambda_{\mathrm{p}}\right) t}-\mathrm{e}^{-\left(\lambda_{2}+\lambda_{\mathrm{p}}\right) t}\right],
\end{aligned}
$$

where

$N_{2}=$ Dairy cow's intake of daughter activity, atoms d-1,

$\lambda_{1}=$ Radioactive decay rate of parent activity, $\mathrm{d}^{-1}$,

$N_{1}^{0}=$ Dairy cow's initial intake of parent activity, atoms d-1,

$\lambda_{2}=$ Radioactive decay rate of daughter activity, $\mathrm{d}^{-1}$,

$I_{1}^{0}=$ Dairy cow's initial intake of parent activity, $\mu \mathrm{Ci} \mathrm{d}^{-1}$.

Milk coricentration of daughter activity can be determined from

$$
\begin{aligned}
C_{m}= & \frac{f_{m} \lambda_{2} I_{1}^{O}}{\left(\lambda_{2}-\lambda_{1}\right)\left(\lambda_{2}+\lambda_{m}-\lambda_{1}-\lambda_{p}\right)\left(\lambda_{m}-\lambda_{p}\right)} \\
& \times\left[\left(\lambda_{m}-\lambda_{p}\right) e^{-\left(\lambda_{1}+\lambda_{p}\right) t}-\left(\lambda_{m}+\lambda_{2}-\lambda_{1}-\lambda_{p}\right) e^{-\left(\lambda_{2}+\lambda_{p}\right) t}\right. \\
& \left.+\left(\lambda_{2}-\lambda_{1}\right) e^{-\left(\lambda_{2}+\lambda_{m}\right) t}\right] .
\end{aligned}
$$


Thyroid concentration of daughter activity is given by

$$
\begin{aligned}
& C_{t}=\frac{f_{m} f_{w} L_{m} \lambda_{2} I_{1}^{o}}{M\left(\lambda_{2}-\lambda_{1}\right)\left(\lambda_{2}+\lambda_{m}-\lambda_{1}-\lambda_{p}\right)\left(\lambda_{m}-\lambda_{p}\right)}
\end{aligned}
$$

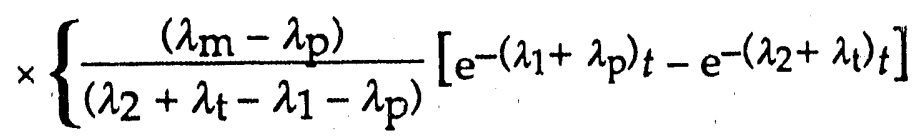

$$
\begin{aligned}
& -\frac{\left(\lambda_{2}+\lambda_{\mathrm{m}}-\lambda_{1}-\lambda_{\mathrm{p}}\right)}{\left(\lambda_{\mathrm{t}}-\lambda_{\mathrm{p}}\right)}\left[\mathrm{e}^{-\left(\lambda_{2}+\lambda_{\mathrm{p}}\right) t}-\mathrm{e}^{-\left(\lambda_{2}+\lambda_{\mathrm{t}}\right) t}\right] \\
& \left.+\frac{\left(\lambda_{2}-\lambda_{1}\right)}{\left(\lambda_{t}-\lambda_{m}\right)}\left[e^{-\left(\lambda_{2}+\lambda_{m}\right) t}-e^{-\left(\lambda_{2}+\lambda_{t}\right) t}\right]\right\} .
\end{aligned}
$$

Integrated thyroid dose from daughter activity is determined from

$$
D_{\mathrm{t}}=\frac{51 E f_{\mathrm{m}} f_{\mathrm{w}} L_{\mathrm{m}} \lambda_{2} I_{1}^{0}}{M\left(\lambda_{1}+\lambda_{\mathrm{p}}\right)\left(\lambda_{2}+\lambda_{\mathrm{t}}\right)\left(\lambda_{2}+\lambda_{\mathrm{p}}\right)\left(\lambda_{2}+\lambda_{\mathrm{m}}\right)} .
$$

Unit-rad deposition for parent activity is given by

$$
F_{1}=\frac{M\left(\lambda_{1}+\lambda_{p}\right)\left(\lambda_{2}+\lambda_{t}\right)\left(\lambda_{2}+\lambda_{p}\right)\left(\lambda_{2}+\lambda_{m}\right)}{51 E f_{m} f_{w} L_{m} \lambda_{2}(U A F)} .
$$

For the sake of completeness and because it may become relatively important during winter conditions, the dose to a child's thyroid resulting from the intake of radioiodine by the cow through inhalation was also calculated.

Dairy cow's inhalation intake is calculated from

$$
Q=0.75 R(I A C) \text {, }
$$

where

$$
\begin{aligned}
Q & =\text { Total intake through inhalation, } \mu \mathrm{Ci}, \\
0.75 & =\text { Fraction inhaled that is absorbed, } \\
R & =\text { Cow's respiration rate, } \mathrm{m}^{3} \mathrm{~h}^{-1} .
\end{aligned}
$$

The concentration in milk, assuming instantaneous equilibration is given by

$$
C_{\mathrm{m}}=K \mathrm{e}^{-\left(\lambda+\lambda_{\mathrm{m}}\right) t} ;
$$

$K$ is a constant which may be evaluated by the following constraint:

where

$$
F_{\mathrm{m} Q}=V \int_{0}^{\infty} C_{\mathrm{m}} \mathrm{dt}
$$

$F_{\mathrm{m}}=$ Total fraction of a single dose recovered in milk, $V=$ Daily milk production, $\mathrm{Ld}^{-1}$. 
However, it has also been shown in Ref. 15 that

$$
\frac{F_{\mathrm{m}}}{V}=\frac{f_{\mathrm{m}}}{\left(\lambda+\lambda_{\mathrm{m}}\right)} \text {. }
$$

Therefore,

$$
\begin{aligned}
C_{\mathrm{m}} & =0.75 f_{\mathrm{m}} R(I A C) \mathrm{e}^{-\left(\lambda+\lambda_{\mathrm{m}}\right) t}, \\
C_{\mathrm{t}} & =\frac{0.75 f_{\mathrm{w}} L_{\mathrm{m}} f_{\mathrm{m}} R(I A C)}{M\left(\lambda_{\mathrm{t}}-\lambda_{\mathrm{m}}\right)}\left[\mathrm{e}^{-\left(\lambda+\lambda_{\mathrm{m}}\right) t}-\mathrm{e}^{-\left(\lambda+\lambda_{\mathrm{t}}\right) t}\right], \text { and } \\
D_{\mathrm{t}} & =\frac{38 E f_{\mathrm{w}} f_{\mathrm{m}} L_{\mathrm{m}} R(I A C)}{M\left(\lambda+\lambda_{\mathrm{m}}\right)\left(\lambda+\lambda_{\mathrm{t}}\right)}
\end{aligned}
$$

Values of the parameters necessary to evaluate these equations are given in Table 9. Values of (UAF) and (MPD) are from Koranda16 and pertain to the western States. Two $(U A F)$ values are given, both for continuous grazing and for green-chop feeding. Green-chop feeding is the most common in the Great Basin area, 17 but single family milk cows may be continuously grazed on pasture. The value of $\lambda_{\mathrm{m}}$ was calculated from data in Legemann, $18 \lambda_{t}$ and $M$ frum data in Rowher and Kaye, ${ }^{19}$ $\lambda_{\mathrm{p}}$ from Thompson, ${ }^{20} V_{\mathrm{g}}$ from $\mathrm{Ng}$ and Tewes, ${ }^{8} \mathrm{R}$ from Black and Barth, 17 and $f_{\mathrm{w}}$ and $E$ from IRCP.12 $L_{\mathrm{m}}$ was chosen as a compromise between the widely used values of 1 and $0.5 \mathrm{~L} \mathrm{~d}^{-1}$. The value of $f_{\mathrm{m}}$ was taken from the review of available data by Garner and Russell. 21

Equation 22 may also be used to evaluate $f_{\mathrm{m}}$, the fraction of daily intake secreted, given $F_{\mathrm{m}}$ (total fraction of a single dose recovered in milk), $V$ (daily milk

\begin{tabular}{|c|c|c|c|c|c|c|}
\hline \multirow{2}{*}{$\begin{array}{l}\text { Independent } \\
\text { parameter } \\
\text { (units) }\end{array}$} & \multirow[b]{2}{*}{ Value } & \multirow{2}{*}{$\begin{array}{c}\text { Dependent } \\
\text { parameter } \\
\text { (units) }\end{array}$} & \multicolumn{4}{|c|}{ Value } \\
\hline & & & $131_{1}$ & $133 \mathrm{I}$ & $131 \mathrm{~m} \mathrm{Te}$ & $132 \mathrm{Te}$ \\
\hline$(U A F)\left(\mathrm{m}^{2} \mathrm{~d}^{-1}\right)$ & & $E(\mathrm{MeV})$ & 0.23 & 0.54 & 0.23 & 0.65 \\
\hline Continuous grazinga & 38 & $\lambda$ or $\lambda_{2}\left(\mathrm{~d}^{-1}\right)$ & 0.0862 & 0.792 & 0.0862 & 7.24 \\
\hline Green chop & 19 & $\lambda_{1}\left(\mathrm{~d}^{-1}\right)$ & - & - & 0.554 & 0.213 \\
\hline$(M P D)\left(\mathrm{kg} \mathrm{d}^{-1}\right)$ & 14 & $F_{1}\left(\mu \mathrm{Ci} \mathrm{m}-2 \mathrm{rad}^{-1}\right)$ & & & & \\
\hline$\lambda_{\mathrm{m}}\left(\mathrm{d}^{-1}\right)$ & 0.64 & Continuous grazing & 0.047 & 1.7 & 0.33 & 21 \\
\hline$\lambda_{t}\left(\mathrm{~d}^{-1}\right)$ & 0.035 & Green chop & 0.094 & 3.4 & 0.66 & 42 \\
\hline$\lambda_{p}\left(d^{-1}\right)$ & 0.050 & & & & & \\
\hline$V_{\mathrm{g}}\left(\mathrm{m} \mathrm{h}^{-1}\right)$ & 40 & & & & & \\
\hline$L_{\mathrm{m}}\left(\mathrm{Ld} \mathrm{d}^{-1}\right)$ & 0.75 & & & & & \\
\hline$M(\mathrm{~g})$ & 2 & & & & & \\
\hline$R\left(\mathrm{~m}^{3} \mathrm{~h}^{-1}\right)$ & 6 & & & & & \\
\hline & 0.3 & & & & & \\
\hline$f_{m}\left(L^{-1}\right)$ & 0.005 & & & & & \\
\hline
\end{tabular}

Table 9. Values of radionuclide-independent parameters and radionuclidedependent parameters necessary to evaluate the radioiodine model, assuming dairy cows are on fresh feed. Calculated values of unit-rad deposition, $F_{1}$, are also given.

a Values are for the western States; the U.S. average is higher. ${ }^{16}$ 
production), and $\lambda+\lambda_{m}$ (the decay constant and biological elimination rate) for a particular radionuclide of iodine. For ${ }^{131} \mathrm{I}$, an aver age value of $F_{\mathrm{m}}$ is $0.06,{ }^{21}$ an average value for the United States for $V$ is $10.1 \mathrm{~L} \mathrm{~d}^{-1}$, 22 and $\left(\lambda+\lambda_{\mathrm{m}}\right)$ is $0.723 \mathrm{~d}^{-1}$. These data yield an $f_{m}$ of $0.0043 \mathrm{~L}^{-1}$, which is in fairly good agreement with the value of $0.005 \mathrm{~L}^{-1}$ listed in Table 9. Also shown in Table 9 are the calculated $F_{1}$ values for

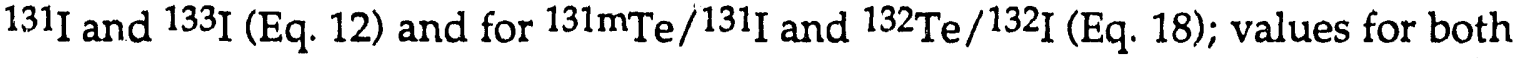
continuous grazing and green-chop feeding are listed.

Table 10 show the estimates of the forage-cow-milk dose for the hypothetical situation that dairy cows were being managed by continuous grazing and the integrated air activity was the same as actually measured. Values for the whole body, bone, and GI tract were computed using the $F_{1}$ values of $\mathrm{Ng}$ et al. ${ }^{14}$ Because they used a (UAF) of $45 \mathrm{~m}^{2} \mathrm{~d}^{-1}$, which is an average for the United States, these results were reduced by the ratio $38 / 45$. The thyroid doses were computed using the $F_{1}$ values listed in Table 9 . Again, the potential dose to the thyroid is clearly the most significant, 1.3 rad. For the management practice of green-chop feeding, this potential dose would be reduced by a factor of 2 . The additional dose resulting from cow-milk transfer through bovine inhalation was calculated using Eq. 25 for ${ }^{131}$ I, ${ }^{133} \mathrm{I}$, and ${ }^{132} \mathrm{Te}$, assuming ${ }^{132} \mathrm{I}$ was in transient equilibrium with ${ }^{132} \mathrm{Te}$. The respective doses are $4.5 \times 10^{-4}, 4.6 \times 10^{-4}$, and $5.2 \times 10^{-6} \mathrm{rad}$. This is insigniticant compared to the potential dose through the forage-cow-milk pathway, but represer $: 18 \%$ of the estimated thyroid dose from human inhalation.

Black and Barth 17 have also developed a predictive model for ${ }^{131}$ I thyroid dose that is based upon empirical observations of the relationship between the peak 131I measured in milk as a function of measured integrated air activity. Many of the observations were field measurements under conditions of nuclear releases at the Nevada Test Site. For green-chop feeding practices, they derived the following infinite dose equation:

$$
D=\frac{0.12(I A C)}{F / C},
$$

where

$$
\begin{aligned}
D= & \text { Dose to a child's thyroid, rad, } \\
(I A C)= & \text { Integrated air activity, } \mu \mathrm{Ci} \mathrm{sec} \mathrm{m}^{-3}, \\
F / C= & \text { Ratio of activity measured on the particulate filter to that on the } \\
& \text { charcoal cartridge. }
\end{aligned}
$$

The use of this model with values of $F / C$ and $(I A C)$ from Tables 2 and 7 gives an 131I thyroid dose of $0.16 \mathrm{rad}$ as compared to $0.47 \mathrm{rad}$ previously calculated. Much of this difference is accounted for by the fact that the green-chop crop measured by Black and Barth had a yield of $1.5 \mathrm{~kg} \mathrm{~m}^{-2}$, while $0.7 \mathrm{~kg} \mathrm{~m}^{-2}$ is an average value for the western States; this latter value is inherent in the (UAF) value of $19 \mathrm{~m}^{2} \mathrm{~d}^{-1}$ listed in Table 9.16 Black and Barth also assumed a child drinks one liter of milk per day. Taking these two factors into account gives virtually perfect agreement between the two models. 
Table 10. Estimated dosage to a child through the forage-cow-milk pathway for a hypothetical dry deposition based upon integrated air activity measured or estimated at Station 1. These estimates are based on the hypothetical situation that dairy cows had been grazed on pasture.

\begin{tabular}{|c|c|c|c|c|c|}
\hline \multirow[b]{2}{*}{ Nuclide } & \multirow{2}{*}{$\begin{array}{l}\text { Hypothetical } \\
\text { ground deposition } \\
\left(\mu \mathrm{Ci} \mathrm{m}^{-2}\right)\end{array}$} & \multicolumn{4}{|c|}{ Dose (rad) } \\
\hline & & Whole body & Bone & GI tract & Thyroid \\
\hline${ }^{3} \mathrm{H}^{\mathrm{b}}$ & $5.6 \times 10^{-2}$ & $5.7 \times 10^{-4}$ & $5.6 \times 10^{-4}$ & $5.6 \times 10^{-4}$ & \\
\hline${ }^{76}$ As & $6.0 \times 10^{-2}$ & $1.3 \times 10^{-5}$ & $1.4 \times 10^{-4}$ & $1.8 \times 10^{-2}$ & \\
\hline${ }^{89} \mathrm{Sr}^{\mathrm{b}}$ & $4.8 \times 10^{-3}$ & $5.9 \times 10^{-4}$ & $4.4 \times 10^{-3}$ & $2.8 \times 10^{-3}$ & \\
\hline $90 \mathrm{Sr}^{\mathrm{b}}$ & $1.9 \times 10^{-6}$ & $5.0 \times 10^{-5}$ & $4.1 \times 10^{-4}$ & $2.9 \times 10^{-6}$ & \\
\hline${ }^{99} \mathrm{Mo}$ & $3.2 \times 10^{-2}$ & $1.5 \times 10^{-3}$ & $6.8 \times 10^{-4}$ & $3.2 \times 10^{-3}$ & \\
\hline${ }^{103} \mathrm{Ru}$ & $6.4 \times 10^{-3}$ & $1.7 \times 10^{-7}$ & $2.6 \times: n-7$ & $1.3 \times 10^{-6}$ & \\
\hline $122 \mathrm{Sb}$ & $2.6 \times 10^{-2}$ & $3.9 \times 10^{-6}$ & $4.4 \times 10^{-6}$ & $3.4 \times 10^{-3}$ & \\
\hline $131 \mathrm{~m} \mathrm{Te}$ & $5.2 \times 10^{-2}$ & $1.9 \times 10^{-5}$ & $2.0 \times 10^{-5}$ & $2.5 \times 10^{-3}$ & $1.6 \times 10^{-1}$ \\
\hline $131_{I^{c}}$ & $4.4 \times 10^{-2}$ & $9.8 \times 10^{-3}$ & $5.2 \times 10^{-3}$ & $1.2 \times 10^{-2}$ & $9.4 \times 10^{-1}$ \\
\hline $132 \mathrm{Te}$ & $1.2 \times 10^{-1}$ & $3.2 \times 10^{-4}$ & $3.5 \times 10^{-4}$ & $2.6 \times 10^{-2}$ & $5.7 \times 10^{-3}$ \\
\hline 133 I $^{\mathrm{C}}$ & $2.6 \times 10^{-1}$ & $2.2 \times 10^{-3}$ & $1.6 \times 10^{-3}$ & $1.0 \times 10^{-2}$ & $1.5 \times 10^{-1}$ \\
\hline${ }^{136} \mathrm{Cs}^{\mathrm{b}}$ & $1.6 \times 10^{-3}$ & $2.0 \times 10^{-3}$ & $2.0 \times 10^{-3}$ & $1.6 \times 10^{-3}$ & \\
\hline${ }^{137} \mathrm{Cs}^{\mathrm{b}}$ & $4.4 \times 10^{-5}$ & $3.7 \times 10^{-4}$ & $3.6 \times 10^{-4}$ & $3.4 \times 10^{-5}$ & \\
\hline Sum (rad) & & $1.7 \times 10^{-2}$ & $1.6 \times 10^{-2}$ & $8.0 \times 10^{-2}$ & $1.3 \times 10^{0}$ \\
\hline
\end{tabular}

Precipitation Deposition. To this point, our analysis of the doses that might have been delivered if dairy cows had been on fresh feed has considered only dry deposition. A much worse case would have occurred if the debris cloud would have encountered precipitation. Crawford and Peterson ${ }^{13}$ have examined this situation using a computer model of cloud diffusion with a rainout option. Their calculations involve the assumption that the entire cloud is rained out at any given distance downwind and that $25 \%$ of the deposition is retained on forage. The result for the Salt Lake City area using these assumptions and Crawford and Peterson's $F_{1}$ value of $3 \times 10^{-2} \mu \mathrm{Ci} \mathrm{m}^{-2} \mathrm{rad}^{-1}$ is a potential dose to the thyroid of $150 \mathrm{rad}$ for ${ }^{131} \mathrm{I}$ alone. For the $F_{1}$ values listed in Table 9, the dose would be $96 \mathrm{rad}$ for continuous grazing and 48 rad for green-chop feeding.

The predictions for thyroid doses for the hypothetical situation that dairy cows were on fresh feed are summarized in Table 11.

\section{Dose Estimate When Dairy Cows Do Not Consume Fresh Feed}

Estimate Based on Integrated Air Activity. The remainder of this analysis will be devoted to an attempt to assess what doses were delivered by the BANEBERRY 
Table 11. Summary of predicted doses in rad to a child's thyroid for the hypothetical situation that dairy cow's were on fresh feed and the integrated air activity was the same as actually occurred.

\begin{tabular}{|c|c|c|c|c|}
\hline \multirow[b]{2}{*}{ Exposure route } & \multicolumn{4}{|c|}{ Dose to thyroid (rad) } \\
\hline & $131_{I}$ & $133_{I}$ & $131 \mathrm{~m} \mathrm{Te} /{ }^{131} \mathrm{I}$ & ${ }^{132} \mathrm{Te} /{ }^{132 \mathrm{I}}$ \\
\hline Human inhalation & $1.8 \times 10^{-3}$ & $3.2 \times 10^{-3}$ & & \\
\hline $\begin{array}{l}\text { Cow-milk through bovine } \\
\text { inhalation }\end{array}$ & $3.7 \times 10^{-4}$ & $3.8 \times 10^{-4}$ & & $4.2 \times 10^{-6}$ \\
\hline Forage-cow-milk & & & & \\
\hline $\begin{array}{l}\text { Continuous grazing } \\
\text { Green chopping }\end{array}$ & $9.4 \times 10^{-1}$ & $1.5 \times 10^{-1}$ & $1.6 \times 10^{-1}$ & $5.7 \times 10^{-3}$ \\
\hline $\begin{array}{l}\text { This paper } \\
\text { Black and Barth } \\
17\end{array}$ & $\begin{array}{l}4.7 \times 10^{-1} \\
1.6 \times 10^{-1}\end{array}$ & $7.5 \times 10^{-2}$ & $8.0 \times 10^{-2}$ & $2.8 \times 10^{-3}$ \\
\hline $\begin{array}{l}\text { Rainout } \\
\text { Continuous grazing } \\
\text { Green chopping }\end{array}$ & $\begin{array}{l}9.6 \times 10^{1} \\
4.8 \times 10^{1}\end{array}$ & & & \\
\hline
\end{tabular}

a From Crawford and Peterson. ${ }^{13}$ Their actual estimate is $1.5 \times 10^{2}$ rad for continuous grazing. Values tabulated above were computed from this by changing the $F_{1}$ value used $\left(3 \times 10^{-2} \mu \mathrm{Ci} \mathrm{m}^{-2} \mathrm{rad}^{-1}\right)$ to those given in Table 9.

venting under the actual conditions, that is, where dairy cows were not on fresh feed. Little effort has been devoted to developing predictive mod sls to cover this situation. Black and Barth ${ }^{17}$ have conducted experiments in which baled hay was exposed to debris from three Plowshare cratering events and have derived an empirical model. Their predictive equation is $D=0.024$ (IAC), which gives a predicted dose of $9.5 \times 10^{-2}$ rad using the integrated air activity measured at Station 1 .

Black and Barth ${ }^{17}$ provide the additional information that the ${ }^{131}$ I concentration $\left(\mu \mathrm{Ci} \mathrm{kg}{ }^{-1}\right)$ attained in growing past re is five to six times that attained in spread hay when exposed to the same debris woud; that the radioiodine deposited on baled hay is about four times less biologically available than that deposited on green chop or spread hay; and that the effective half-life of ${ }^{131}$ I on baled or spread hay is longer than on growing pasture ( $6.5 \mathrm{~d}$ versus $4.2 \mathrm{~d}$ ).

A change in the effective half-life seems reasonable because part of the rate of loss on fresh pasture is presumably due to plant growth and growing-plant physiology factors. ${ }^{15}$ Moreover, an effective half-life of $6.5 \mathrm{~d}$ has also been measured on pasture during winter ${ }^{15}$ when these factors would not apply. However, it is difficult to accept that radioiodine is less biologically available when deposited on baled hay than when it is deposited on spread hay. Black and Barth explained this effect based on the chemical state and/or relatively large particles of the debris released by the three Plowshare events (green chop and spread hay experiments were done with non-excavation events). If that is correct, different biological availability for radioiodine on baled and spread hay probably would not hold true in 
the Salt Lake City area because the deposited radioiodine we ld necessarily be contained on very small particles.

The observation that less radioactivity is deposited per $\mathrm{kg}$ of spread hay than of growing pasture is difficult to interpret in terms of an analytical model. Equation 2 indicates that this observation could be explained by a change in the deposition velocity, density, or both; in all likelihood, the density was different for the two cases.

Because most of the contamination would presumably be confined to the surface of the haystack, an adequate analytical model cannot be developed for the stored feed situation without intimate knowledge of the geometrical features of a particular haystack and a farmer's removal practice. There is also inadequate knowledge concerning the deposition process on such complex structures. With these reservations in mind, we attempted an approximation of such a model. A worst-case assumption was made that a haystack consists of a single bale of hay measuring $38.5 \mathrm{~cm} \times 46.2 \mathrm{~cm} \times 102.6 \mathrm{~cm}$ (15 in. $\times 18$ in. $\times 40$ in.), weighing $68.2 \mathrm{~kg}$ $(125 \mathrm{lb})$, with a $10 \%$ moisture content; we believe this represents a typical bale of hay. ${ }^{23}$ On this basis, Eq. 2 may be used to calculate the concentration attained in the "haystack" using the normal $V_{\mathrm{g}}$ and a $D$ calculated from above of $110 \mathrm{~kg}$ (dry) $\mathrm{m}^{-2}$. This may underestimate the concentration attained in a single bale because a single bale has much more exposed surface area, but on the average it should provide a reasonable result because bales are stored in stacks, not singly. Because the effective half-life on hay is longer as note above, $\lambda_{p}$ should be decreased from $0.050 \mathrm{~d}^{-1}$ to $0.020 \mathrm{~d}^{-1}$.

Unit-rad deposition values may then be calculated for stored feed situations using the following:

$$
\begin{aligned}
& F_{1}^{\prime}=\frac{F_{1} D(U A F)\left(\lambda+\lambda_{\mathrm{p}}^{\prime}\right)}{(M P D)\left(\lambda+\lambda_{\mathrm{p}}\right)} \text { and } \\
& F_{i}=\frac{F_{1} D(U A F)\left(\lambda_{1}+\lambda_{\mathrm{p}}^{\prime}\right)\left(\lambda_{2}+\lambda_{\mathrm{p}}^{\prime}\right)}{(M P D)\left(\lambda_{1}+\lambda_{\mathrm{p}}\right)\left(\lambda_{2}+\lambda_{\mathrm{p}}\right)},
\end{aligned}
$$

where the prime designation refers to parameters modified for stored feed and Eqs. 26 and 27 are analogous to Eqs. 12 and 18 respectively. The modified parameters and the computed values of $F_{1}^{\prime}$ are tabulated in Table 12 .

Tabie 12. Modified values of parameters necessary to evaluate stored feed radioiodine model. Calculated values of unit-rad deposition are also given.

\begin{tabular}{lc|cc}
\hline \multicolumn{2}{c|}{ Modified parameters } & \multicolumn{2}{c}{ Unit-rad deposition values } \\
\hline Parameter & Value & Radionuclide & $F_{1}^{\prime}\left(\mu \mathrm{Ci} \mathrm{m}^{-2} \mathrm{rad}^{-1}\right)$ \\
\hline$D_{1}(\mathrm{dry})\left(\mathrm{kg} \mathrm{m}^{-2}\right)$ & 110 & $131_{\mathrm{I}}$ & $1.1 \times 10^{1}$ \\
$\lambda_{p}^{\prime}\left(\mathrm{d}^{-1}\right)$ & 0.020 & $133_{\mathrm{I}}$ & $4.9 \times 10^{2}$ \\
& & $131 \mathrm{~m}_{\mathrm{Te}}$ & $7.3 \times 10^{1}$ \\
& & $132 \mathrm{Te}$ & $5.3 \times 10^{3}$ \\
\hline
\end{tabular}


For ${ }^{131} \mathrm{I}, \mathrm{Eq} .26$ and the value of $A_{\mathrm{o}}$ from Table 10 (ground deposition equals forage contamination) gives a dose of $4.0 \times 10^{-3} \mathrm{rad}$. This a factor of 24 lower than the dose computed using the Blacis and Barth model. This is surprising because the analytical model used here was presumed to represent a worst case. The discrepancy involves the relationship between integrated air activity and baled hay contamination. The data in Black and Barth for baled hay contamination versus integrated air activity fit Eq. 2 only if $D$ is about $1.5 \mathrm{~kg} \mathrm{~m}^{-2}$. This indicates that the deposition process is about 100 times more efficient on a bale of hay than it is on fresh forage or that some less obvious factors are involved. One such factor could be that the debris associated with the three Plowshare cratering events (and the baled hay exposure studies) contained particles too large to be sampled by the air samplers used. Such effects were documented in the SCHOONER cratering event. ${ }^{24} \mathrm{We}$ calculated deposition velocities, $V_{\mathrm{g}}$, using Black and Barth's measurements of ground deposition and their integrated air activity values. ${ }^{17}$ For the baled hay experiments, $V_{\mathrm{g}}$ had a median value of $1300 \mathrm{~m} \mathrm{~h}^{-1}$ with a range of 380 to $7200 \mathrm{~m} \mathrm{~h}^{-1}$. This is 30 times higher than values normally reported and indicates that the air sampler used was not efficient for the debris released by these events. In contrast, during the studies of green-chop contamination, the median deposition velocity was $50 \mathrm{~m} \mathrm{~h}^{-1}$ with a range of 18 to $2800 \mathrm{~m} \mathrm{~h}^{-1}$, with the one excessively high value again resulting from a Plowshare cratering event. The possible presence of such large particles would also explain the observed decrease in biological availability during the baled hay experiments.

Estimate Based on Hay and Milk Measurements. Following the BANEBERRY venting, EPA ${ }^{4}$ and Pendleton et al. ${ }^{1}$ took many measurements of baled hay and milk in Utah. (LRL acquired ciata on hay, milk, and dairy cows near NTS; see Appendix C.) EPA measured cow feed samples at five locations and found no detectable ${ }^{132} \mathrm{Te},{ }^{131} \mathrm{I},{ }^{133} \mathrm{I}$, or ${ }^{135} \mathrm{I}$. They also measured milk samples at 12 locations and repcitied that all but one sample had less than $20 \mathrm{pCi} \mathrm{L}^{-1}$ of ${ }^{131} \mathrm{I}$. The exception was at Mt. Pleasant, Utah, and a value of $60 \mathrm{pCi} \mathrm{L}^{-1}$ was reported for a sample collected on December 24, 1970. This result is, however, inconsistent with airsampling results showing where the cloud crossed the State (Mt. Pleasant is close to Station 33). In fact, this sample may not have contained ${ }^{131}$ I. It has been acknowledged by EPA that the computer algorithm used for gamma spectral analysis can mistakenly identify radon daughters as ${ }^{131}{ }^{4}{ }^{4}$ This is known to have happened with one sample from Riverton, Wyoming, originally thought to contain $70 \mathrm{pCi} \mathrm{L}^{-1}$ of ${ }^{131} \mathrm{I}$.

Pendleton et al. ${ }^{1}$ measured significant amounts of $131 \mathrm{I}$ in baled hay at four locations, Stations 1, 4, 71, and 78, where they found 1248, 1014, 2702, and $2178 \mathrm{pCi} \mathrm{kg}^{-1}$ dry wt, respectively, corrected to December 20th. These numbers represent an overestimate of the true contamination levels because they represent the exposed surfaces only, but they can be used to estimate an upper-limit dose using Eqs. 3 and 10 with $\lambda_{p}^{\prime}$ substituted for $\lambda_{\mathrm{p}}$. The results are $1.2 \times 10^{-2}, 1.0 \times 10^{-2}$, $2.7 \times 10^{-2}$, and $2.2 \times 10^{-2} \mathrm{rad}$ for the respective stations. 
Pendleton et al. also detected $35 \mathrm{pCi} \mathrm{L}^{-1}$ of $131 \mathrm{I}$ in one sample of milk at Station 1, which was a composite of milkings from December 24th, 25th, and 26th. They al $\%$ detected ${ }^{131} \mathrm{I}$ in three samples from Station 4: a sample of milk from December 25th contained $49 \mathrm{pCi} \mathrm{L}^{-1}$, a composite sample of December 26th and 27th contained $54 \mathrm{pCi} \mathrm{L}^{-1}$, and a sample from December 28 th contained $37 \mathrm{pCi} \mathrm{L}^{-1}$. These values may also be used to calculate the dose to a child's thyroid by using Eq. 6 to evaluate $f_{m} I_{0} /\left(\lambda_{m}-\lambda_{p}^{\prime}\right)$ with averaging and decay correcting for composite samples. This may then be used to calculate a thyroid dose using Eq. 10. The results for the respective samples are $6.5 \times 10^{-3}, 8.4 \times 10^{-3}, 1.1 \times 10^{-2}$, and $8.5 \times 10^{-3} \mathrm{rad}$.

The results of all these calculations for the estimate of the actual dose potential to a child's thyroid (assuming negligible delay between production and consumption of milk) are summarized in Table 13. The "worst case" single-bale haystack model actually underestimated the dose based upon the measurements of baled hay and milk samples. The actual hay measurements are biased upward because only the surface of exposed bales is sampled. ${ }^{1}$ Milk measurements may also give an upward bias of the total integrated dose if the supply of exposed bales is

Table 13. Summary of predicted doses to a child's thyroid for the actual conditions of the BANEBERRY vent. Results include predictions based on our analytical model, Black and Barth's empirical model, and measured levels in hay and milk.

\begin{tabular}{|c|c|c|c|c|}
\hline Location & & Dose $t$ & roid (rad) & \\
\hline Exposure route & 131 I & $133 \mathrm{I}$ & $131 \mathrm{~m} \mathrm{Te} /{ }^{131} \mathrm{I}$ & $132 \mathrm{Te} / 132 \mathrm{I}$ \\
\hline Station 1 & & & & \\
\hline Human inhalation & $1.8 \times 10^{-3}$ & $3.2 \times 10^{-3}$ & & \\
\hline Cow rnilk through bovine inhalation & $3.7 \times 10^{-4}$ & $3.8 \times 10^{-4}$ & & $4.2 \times 10^{-6}$ \\
\hline Baled hay-cow-milk & & & & \\
\hline This paper & $4.0 \times 10^{-3}$ & $5.3 \times 10^{-4}$ & $7.1 \times 10^{-4}$ & $2.3 \times 10^{-5}$ \\
\hline Black and Barth ${ }^{17}$ & $9.5 \times 10^{-2}$ & & & \\
\hline Based on hay measurement ${ }^{1}$ & $1.2 \times 10^{-2}$ & & & \\
\hline Based on milk measurement ${ }^{1}$ & & & & \\
\hline $12 / 26 / 70$ & $6.5 \times 10^{-3}$ & & & \\
\hline Station 4 & & & & \\
\hline Based on hay measurement ${ }^{1}$ & $1.0 \times 10^{-2}$ & & & \\
\hline Based on milk measurement ${ }^{1}$ & & & & \\
\hline $12 / 25 / 70$ & $8.4 \times 10^{-3}$ & & & \\
\hline $12 / 27 / 70$ & $1.1 \times 10^{-2}$ & & & \\
\hline $12 / 28 / 70$ & $8.5 \times 10^{-3}$ & & & \\
\hline Station 71 & & & & \\
\hline Based on hay measurement ${ }^{1}$ & $2.7 \times 10^{-2}$ & & & \\
\hline Station 78 & & & & \\
\hline Based on hay measurement ${ }^{1}$ & $2.2 \times 10^{-2}$ & & & \\
\hline
\end{tabular}


rapidly used up, or if exposed bales are not used until the ${ }^{131}$ I has decayed. A reasonable estimate of the total thyroid dose at Station 1 is approximately $1.1 \times 10^{-2} \mathrm{rad}$.

\section{Conclusions}

The air-sampling network of 15 stations performed very well in defining the airborne concentrations in Utah of radionuclides released by the venting of the BANEBERRY event. Integrated concentrations of ${ }^{131}$ I ranged from not detectable (ND) in St. George to $1100 \mathrm{pCi} \mathrm{h} \mathrm{m}^{-3}$ at Draper (near Salt Lake City). At Draper, the sum of the fraction of the concentration guidance for all 14 radionuclides detected or estimated was 0.011 . By far the largest dose via inhalation was to the thyroid, and this dose was about $0.005 \mathrm{rad}$. We also examined the dose to the infant thyroid via the cow-milk pathway, and we considered both the real situation following BANEBERRY and the hypothetical situation if the venting had taken place when dairy cows had been on pasture. This analysis was facilitated by the collection and analysis of additional samples of feed and milk.

For the actual conditions following the BANEBERRY venting, we estimate on the basis of measurements of baled hay and or milk that the dose to an infant's thyroid via the cow-milk pathway was between 0.0065 and 0.012 rad at Draper. If cows had been continuously on fresh pasture, we estimate that the dose to the infant thyroid for the same integrated air concentration would have been 1.3 rad for dry deposition and up to 100 rad for wet deposition.

\section{Acknowledgments}

We are deeply indebted for the help received from several members of the LRL Bio-Medical Research Division Staff, especially to G. Holladay, G. Huckabay, M. Stuart, A. Bradley, D. McIntyre, and G. Vattuone; invaluable assistance in maintaining the field sampling equipment was provided by Cleo Fry and John C. Taylor. In addition, it would have been impossible to carry this work out without the help of W. Wagner and R. Lloyd of the University of Utah. We also thank Jared Davis of the Nevada Operations Office for his support of this project.

Finally, we thank Gretchen Gallegos for her skillful rewriting and rearrangement of our rough draft. 


\section{References}

1. R.C. Pendleton, W.W. Wagner, R.D. Lloyd, and C.W. Mays, Interim Report: Radioactive Fallout in Utah Following the BANEBERRY Event, University of Utah Report, Salt Lake City, UT (February 1970).

2. L.R. Anspaugh, B.J. Clegg, J.J. Cohen, R.J. Grabske, F.L. Harrison, R.E. Heft, G. Holladay, J.J. Koranda, Y.C. Ng, P.L. Phelps, and G.B. Potter, Bio-Medical Division Preliminary Report for Project SCHOONER, Lawrence Radiation Laboratory, Livermore, CA, UCRL-50718 (1969).

3. P.L. Phelps, K.O. Hamby, B. Shore, and G.B. Potter, "A Ge(Li) Gamma-Ray Spectrometer of High Sensitivity and Resolution for Biological and Environmental Counting," in Radionuclides in the Environment (American Chemical Society, Washington, DC, 1970), pp. 202-230.

4. Environmental Protection Agency (EPA), Interim Report of Off-Site Surveillance for the BANEBERRY Event, December 18, 1970, Southwestern Radiological Health Laboratory, Environmental Protection Agency, Las Vegas, NV (January 1971).

5. R.E. Heft, Lawrence Radiation Laboratory, Livermore, CA, private communication (1971).

6. R.C. Pendleton, C.W. Mays, R.D. Lloyd, and A.L. Brooks, "Differential Accumulation of 131I from Local Fallout in People and Milk," Health Phys. 9, 1253-1262 (1962).

7. Y.C. $\mathrm{Ng}$ and S.E. Thompson, Prediction of the Maximum Dosage to Man from the Fallout of Nuclear Devices. II. Estimation of the Maximum Drse from Internal Emitters, Lawrence Radiation Laboratory, Livermore, CA, I JCRL-50163, Part II (1966).

8. Y.C. Ng and H.A. Tewes, Radionuclide Body Burdens and Hazards from Ingestion of Foodstuffs Contaminated by Fallout, Lawrence Radiation Laboratory, Livermore, CA, UCRL-72716, Revision I (1970).

9. V.E. Andrews, Southwestern Radiological Health Laboratory, Environmental Protection Agency, Las Vegas, NV, private communication (1971).

10. R.H. Ide, Lawrence Radiation Laboratory, Livermore, CA, private communication (1971).

11. "Standards for Radiation Protection," Chapter 0524 in AEC Manual (U.S. Atomic Energy Commission, Washington, DC, 1968).

12. "Report of ICRP Committee II on Permissible Dose for Internal Radiation (1959)," Health Phys. 3, 1-230 (1960).

13. K.R. Peterson and T.V. Crawford, Lawrence Radiation Laboratory, Livermore, CA, private communication (1971). 
14. Y.C. Ng, C.A. Burton, S.E. Thompson, R.K. Tandy, H.K. Kretner, and M.W. Pratt, Prediction of the Maximum Dosage to Man from the Fallout of Nuclear Devices. IV. Handbook for Estimating the Maximum Internal Dose from Radionuclides Released to the Biosphere, Lawrence Radiation Laboratory, Livermore, CA, UCRL-50163, Part IV (1968).

15. D.F. Bunch, Ed., Controlled Environmental Radioiodine Tesis Progress Report Number Two, Idaho Operations Office, U.S. Atomic Energy Commission, IDO-12053 (1966).

16. J.J. Koranda, Agricultural Factors Affecting the Daily Intake of Fresh Fallout by Dairy Cows, Lawrence Radiation Laboratory, Livermore, CA, UCRL-12479 (1965).

17. S.C. Black and D.S. Barth, Rodioiodine Prediction Model for Field Events, Southwestern Radiological Health Laboratory, Environmental Protection Agency, Las Vegas, NV, SWRHL-109r (1971).

18. F.W. Lengemann, "Predicting the Total Projected Intake of Radioiodine from Milk by Man. 1. The Situation Where No Counter Measures Are Taken," Health Phys. 12, 825-830 (1966).

19. P.S. Rohwer and S.V. Kaye, Predicting Radiation Dose Equivalents for Populations: II. Results Obtained with Dose Models, Symposium on Sea-Level Canal Bioenvironmental Studies, Paper 5 - Issues as IOCS Memorandum BMI-24 by Battelle Memorial Institute, Columbus, $\mathrm{OH}$ (1969).

20. S.E. Thompson, Effective Half-Life of Fallout Radionuclides on Plants with Special Emphasis on Iodine-131, Lawrence Radiation Laboratory, Livermore, CA, UCRL-12388 (1965).

21. R.J. Garner and R.S. Russell, "Isotopes of Iodine," in Radioactivity and Human Diet, R.S. Russell, Ed. (Pergola Press, New York, NY, 1966), p. 297.

22. Milk Production, Statistical Reporting Service, Crop Reporting Board, U.S. Department of Agriculture, Washington, DC, DA-1-1 (June 1964).

23. J.H. Rehder, Lawrence Radiation Laboratory, Livermore, CA, private communication (1971).

24. L.R. Anspaugh, P.L. Phelps, G. Holladay, and K.O. Hamby, "Distribution and Redistribution of Airborne Particulates from the SCHOONER Cratering Event," in Proceedings of the 5th Annual Health Physics Society Midyear Topical Symposium: Health Physics Aspects of Nuclear Facility Siting (Eastern Idaho Health Physics Society, Idaho Falls, ID, 1970), vol. 2, pp. 428-446. 


\title{
Appendix A
}

\section{BANEBERRY Meteorological Data and Interpretation for Eastern Nevada and Utah}

\author{
K.R. Peterson and T.V. Crawford
}

\section{Surface Weather Maps}

Surface weather maps covering eastern Nevada and Utah for five days after the BANEBERRY venting are presented in Figs. A-1 to A-9. Maps are at 12-h intervals, except the last three, which are at 24-h intervals. All times are Mountain Standard Time (MST). The maps depict the weather occurring at observation time, where " $O$ " represents rain, " $*$ " is for snow, and " $\equiv$ " indicates fog. Also shown are areas of extensive clouds with bases below 5,000 to 6,000 ft above the ground; these cloud areas are depicted by the cycloid-shaped lines. The cusps point toward cloudy areas. Finally, the winds are presented in standard meteorological notation. The arrows "fly with the wind," i.e., a wind of

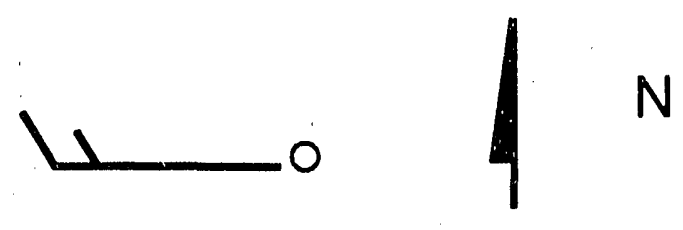

blows from the west. Speeds are indicated by barbs at the end of the shafts. Hence,

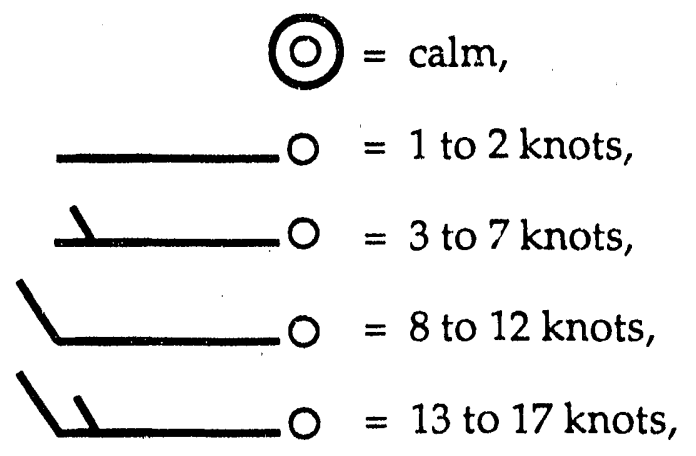

and so on. 
Our data source was National Weather Service maps; observation stations are entered only when they appeared on the source maps.

Scattered snow areas are present on nearly every map. Snow became more widespread on December 19th and 20th, and was observed at nearly all reporting stations on the 21 st. This wide-spread snowfall would scavenge nearly all debris that might have been drifting around or might have been trapped in valleys.

\section{Debris Trajectories}

Most of the surface wind observations are light and variable and appear to be strongly influenced by local topography. These winds in such mountainous terrain precluded construction of a near-surface debris trajectory. The Air Resources Laboratory, Las Vegas, NV, part of the National Oceanic and Atmospheric Administration, has combined low-level $(1,000$ to $2,000 \mathrm{ft})$ winds from their supplementary observation network with reports of radioactivity. It appears that the low-level-wind debris drifted slowly northward, as far as Winnemucca and Elko. Beyond this, the near-surface cloud diverged, with part of it continuing northward, another part heading into Utah, and a third portion moving southwestward toward Bishop, CA. Some of the surface air samples taken in Utah on December 20th and 21st probably were from this cloud, with some contribution for redeposition of surface debris.

Trajectories of the leading edge of the debris cloud were estimated from upper air winds, using results of aircraft sampling to make minor adjustments. Because the vertical wind shear was large, we constructed trajectories centered at three different altitudes, i.e., $8,000,10,000$, and $12,000 \mathrm{ft}$ above mean sea level (MSL). These are shown in Fig. A-10. All times are Mountain Standard Time. The 8,000-ft trajectory headed up the Snake River Valley and apparently diffused downward, giving positive readings on the air samplers in Idaho. Northern Utah was most affected by debris that diffused down from the trajectory centered at $10,000 \mathrm{ft}$; this trajectory passed over Salt Lake City about $24 \mathrm{~h}$ after the BANEBERRY venting. Southern Utah was exposed to debris that diffused downward from the trajectory centered at $12,000 \mathrm{ft}$. The arrival at the surface was delayed several hours after passage of the leading edge at $12,000 \mathrm{ft}$. This was consistent with observations from the SCHOONER main cloud and can be explained by the longer time for material to diffuse to the surface from this portion of the cloud.

\section{Temperature and Dew-Point Soundings}

The vertical temperature structure along a debris-cloud trajectory is important because when temperature increases with height (a temperature inversion) the further upward diffusion of material is impeded. The same principle applies to inversions below the cloud base. Figure A-11 depicts the variation of temperature and dew point with altitude for Yucca, NV, at the time of venting and at Salt Lake City, about 3 or $4 \mathrm{~h}$ prior to arrival of the middle $(10,00 \mathrm{ft})$ debris cloud. 
The Yucca sounding shows no indication of a temperature inversion above the cloud, at least up to $18,000 \mathrm{ft}$ (MSL). There is a surface temperature inversion whose top is between 3,00 ) to $5,000 \mathrm{ft}$. The Salt Lake City sounding indicates a slight temperature inversion at 16,000 to $17,000 \mathrm{ft}$, but this is far enough above the middle part of the debris cloud $(10,000 \mathrm{ft})$ that upward diffusion would be virtually unimpeded. The top of the surface inversion at Salt Lake City is almost 5,000 ft (MSL). Conseq'!ently, any locations above 5,000 ft would have, at most, a shallow temperature inversion at night that would be removed through surface heating by midmorning.

The dew-point profiles show relatively dry air, except between 14,500 and $17,000 \mathrm{ft}$ at Salt Lake City. The moist layer corresponds to a cloud layer at these heights during the observation time.

Figure A-11 also includes the dry adiabatic lapse rate. When the temperature profile parallels this curve, vertical mixing occurs freely. Such conditions occur commonly during warm, summer days. The Yucca and Salt Lake City temperature profiles are less than the dry adiabatic, indicating that mixing and consequent dilution of the debris cloud is less than it would be on a clear, summer day.

\section{Discussion}

The approximate elevations of the Utah surface air-sampling sites are shown in Fig. A-12; the 10,000-ft debris trajectory is reproduced on this diagram. At 5:00 a.m. MST, December 19th, Salt Lake City, at $4200 \mathrm{ft}$, had a surface inversion with its top at about $4800 \mathrm{ft}$. Those sampling sites near the 10,000-ft debris trajectory that are located higher than Salt Lake City would be expected to have higher radiation readings from BANEBERRY because the surface temperature inversion was probably shallower and would be destroyed by heating sooner during the morning. This hypothesis is borne out by the results of gross measurements at Salt Lake City (4200 ft) and Snyderville (6800 ft) of Pendleton et al. ${ }^{1}$; when Pendelton's values are corrected to the mean sampling time, using the $t^{1.2}$ relationship, the values at Salt Lake City and Snyderville are about 1200 and $2000 \mathrm{pCi} \mathrm{m}^{-3}$, respectively.

The weather, debris-cloud trajectories, and diffusion conditions for BANEBERRY were fairly typical of winter conditions. Surface air concentrations would have been higher, by perhaps a factor of 2 or 3 , if there had been more vertical mixing in the Utah area and a strong temperature inversion present at the top of the debris cloud. Rain or snow of sufficient intensity and duration to scavenge the entire cloud above a particular location are the most important factors that could have made the dose to Utah significantly larger than was observed. 


\section{Reference}

1. R.C. Pendleton, W.W. Wagne', R.D.Lloyd, and C.W. Mays, Interim Report: Radioactive Fallout in Utah Following the BANEBERRY Event, University of Utah Report, Salt Lake City, UT (February 1970). 


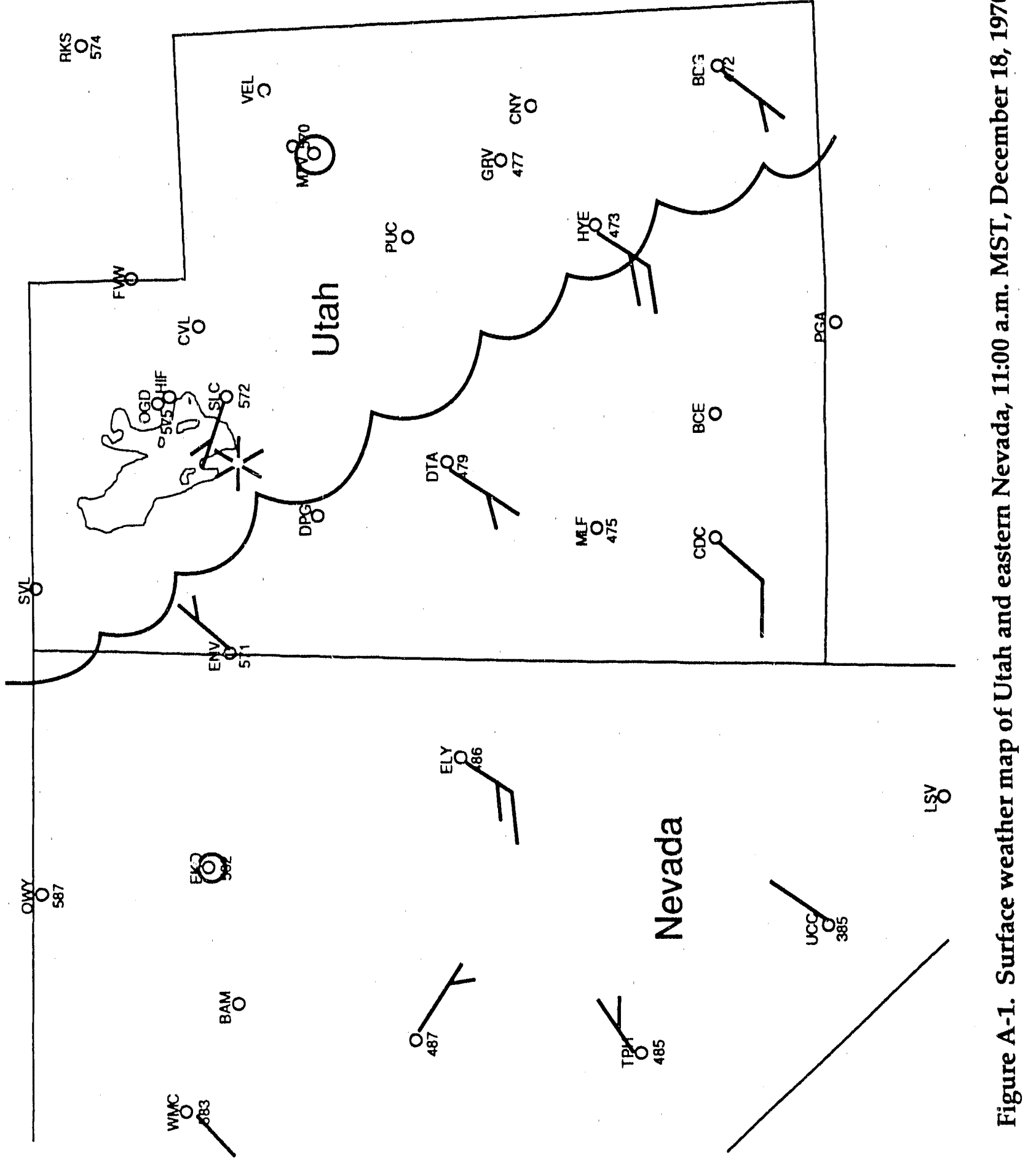




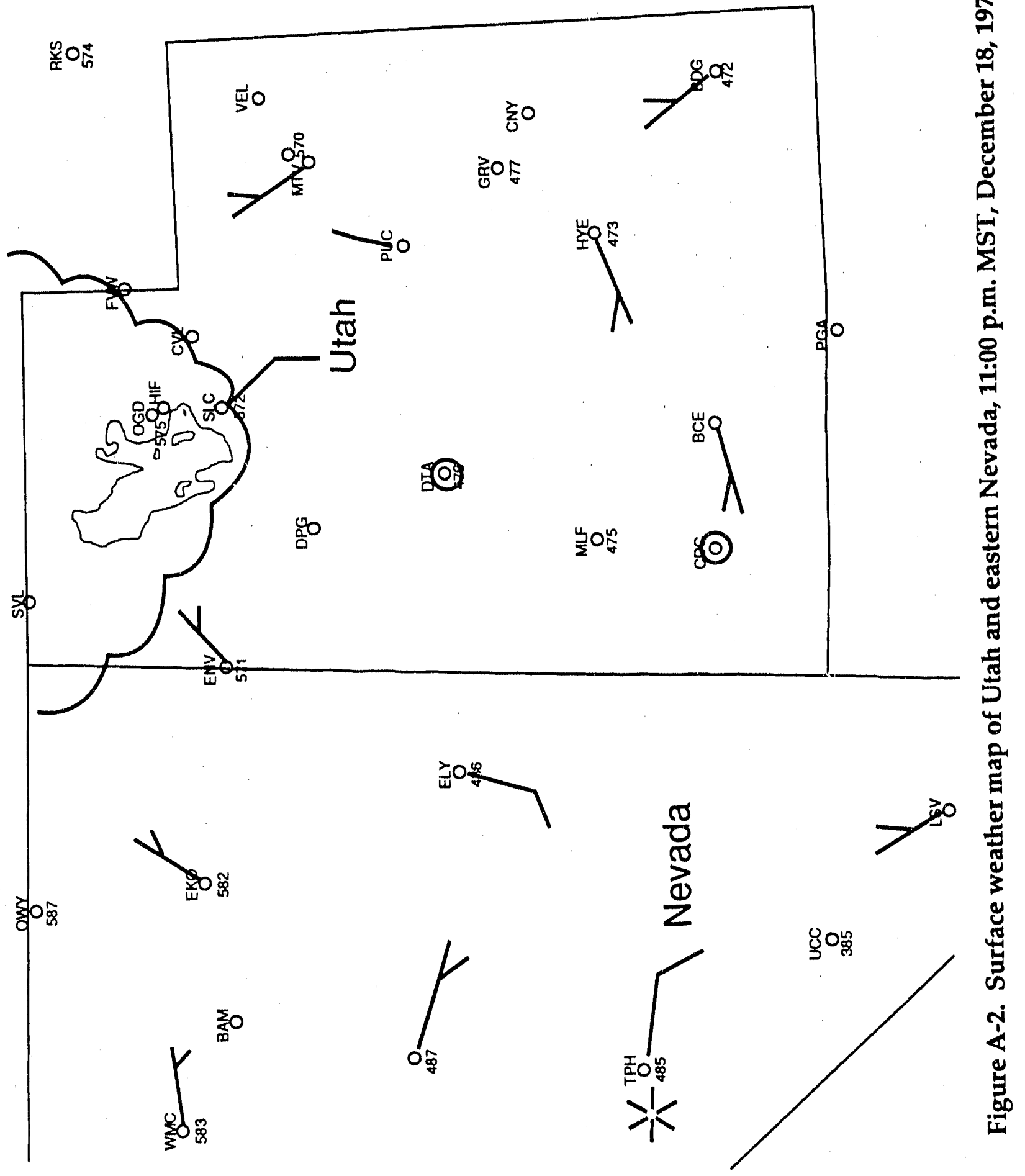




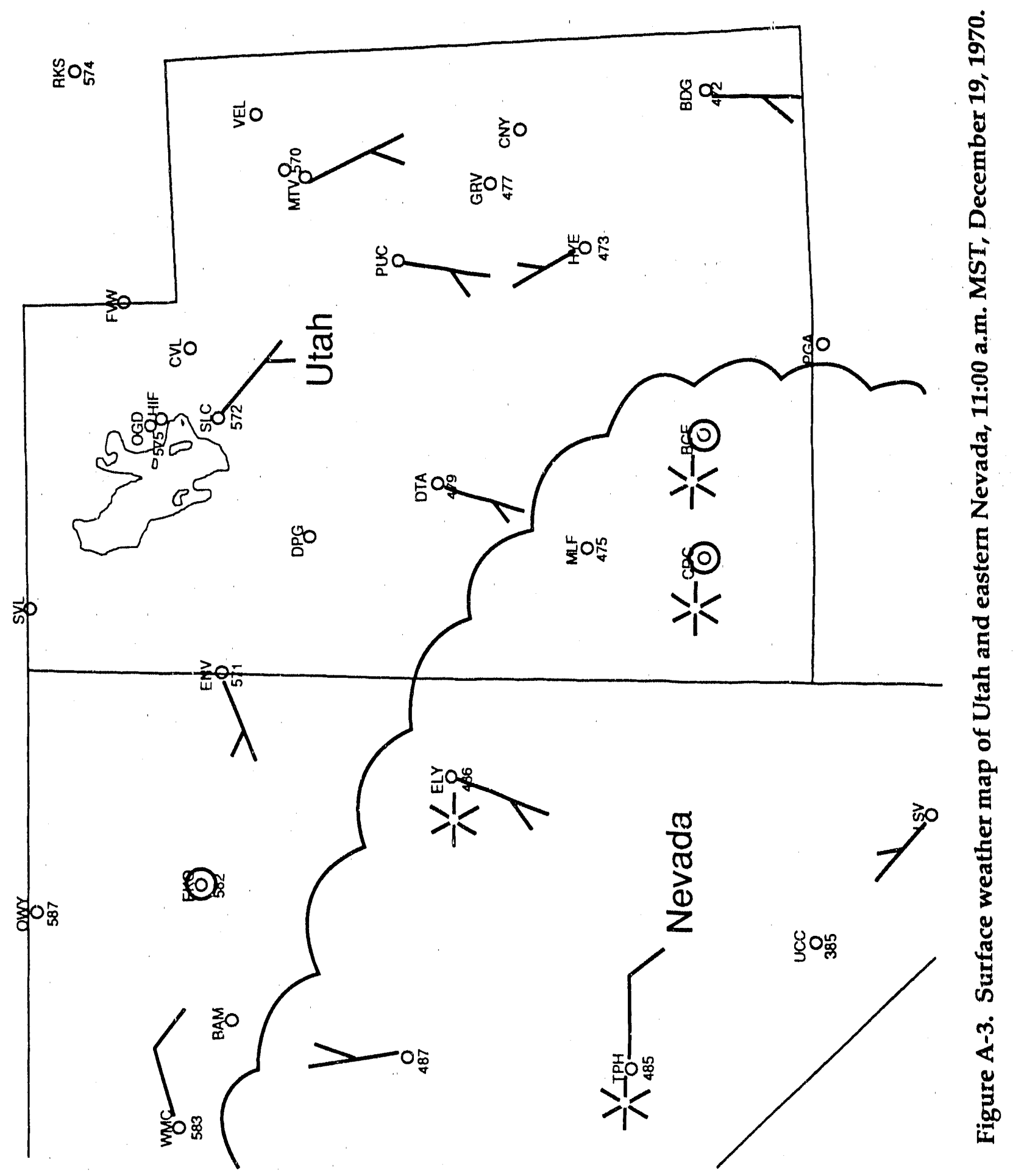




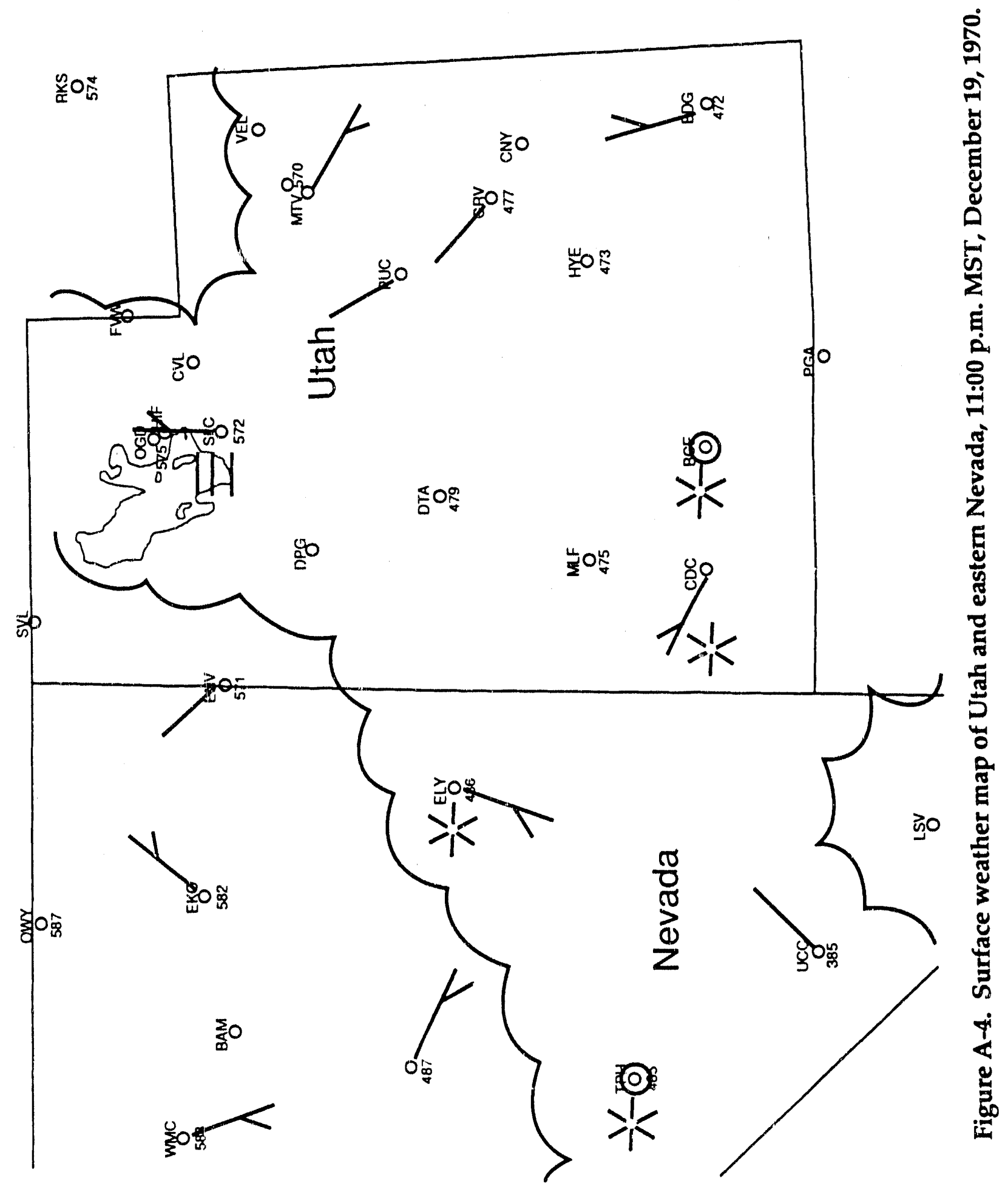




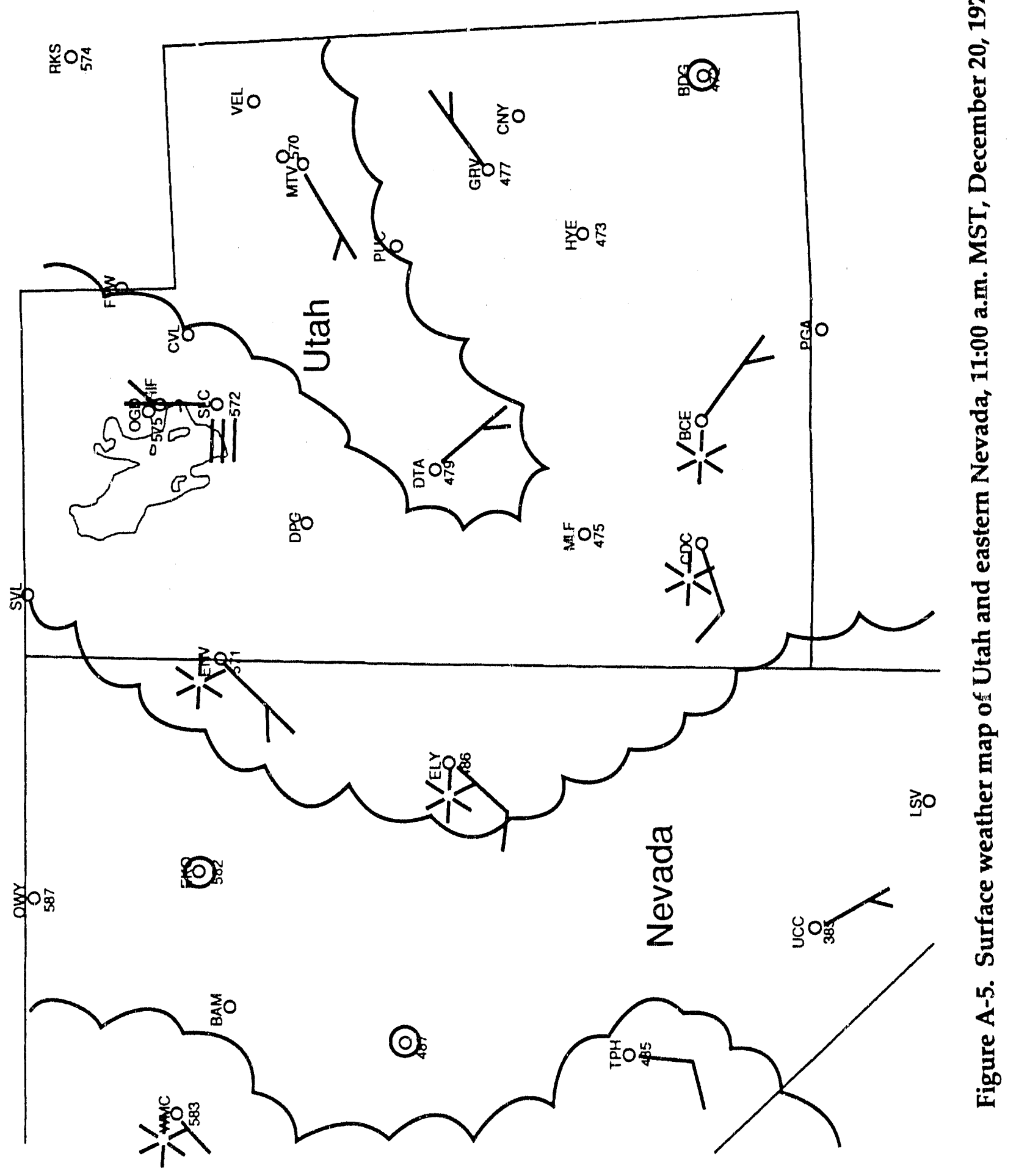




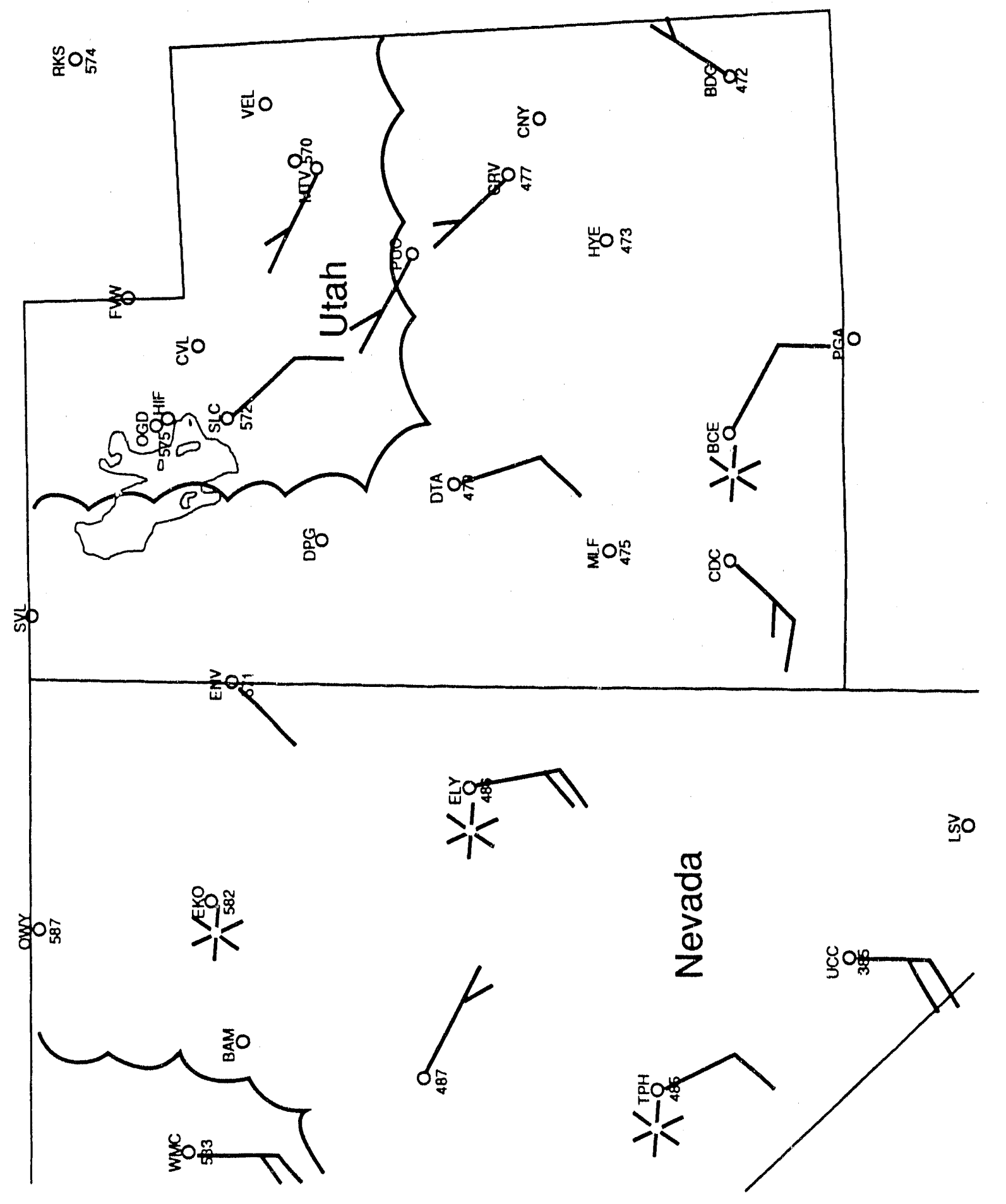

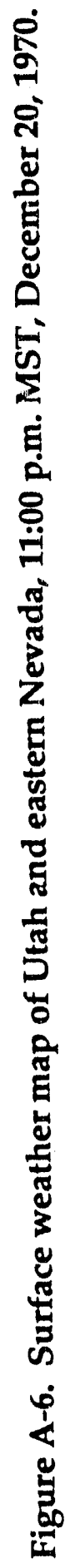




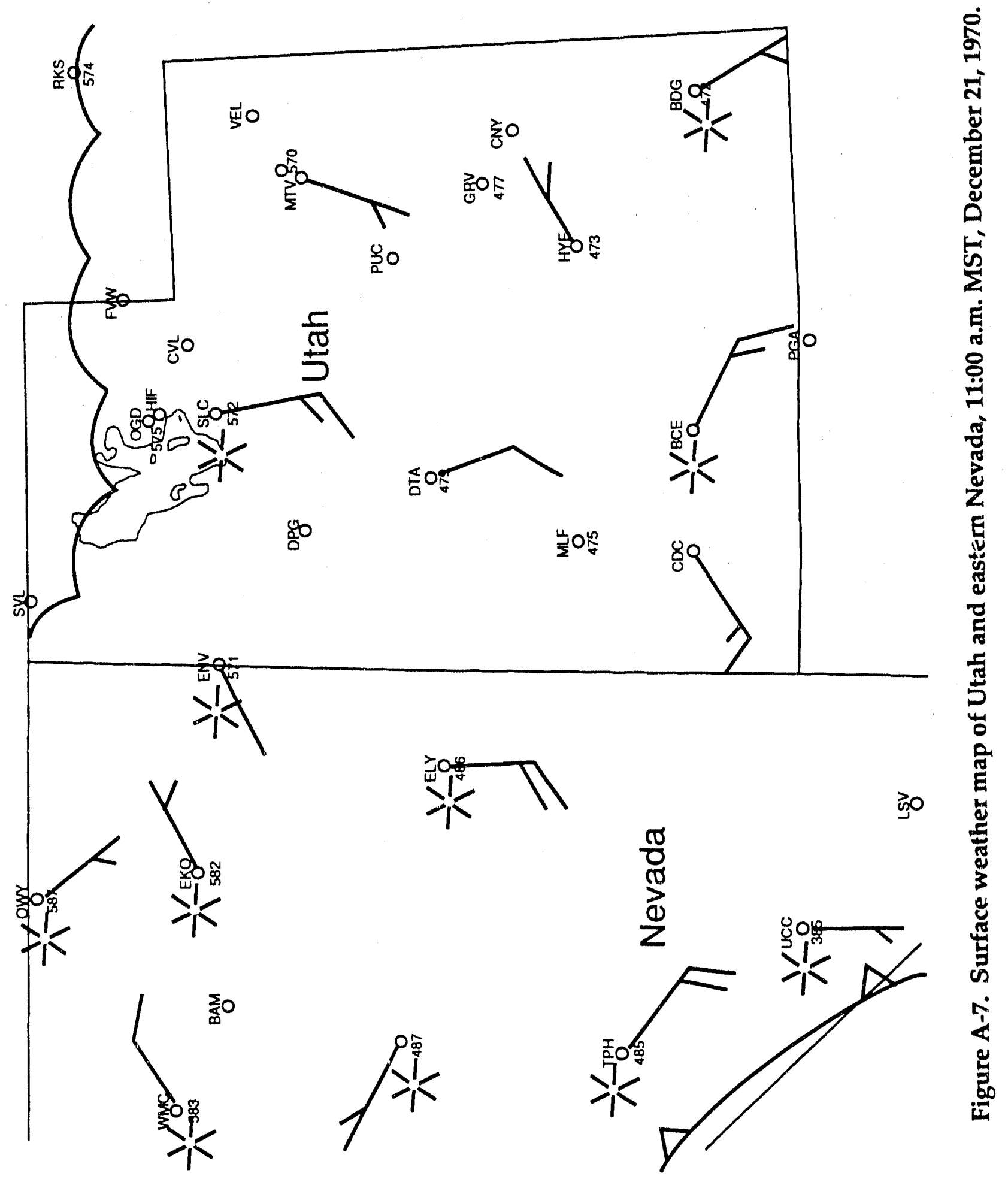




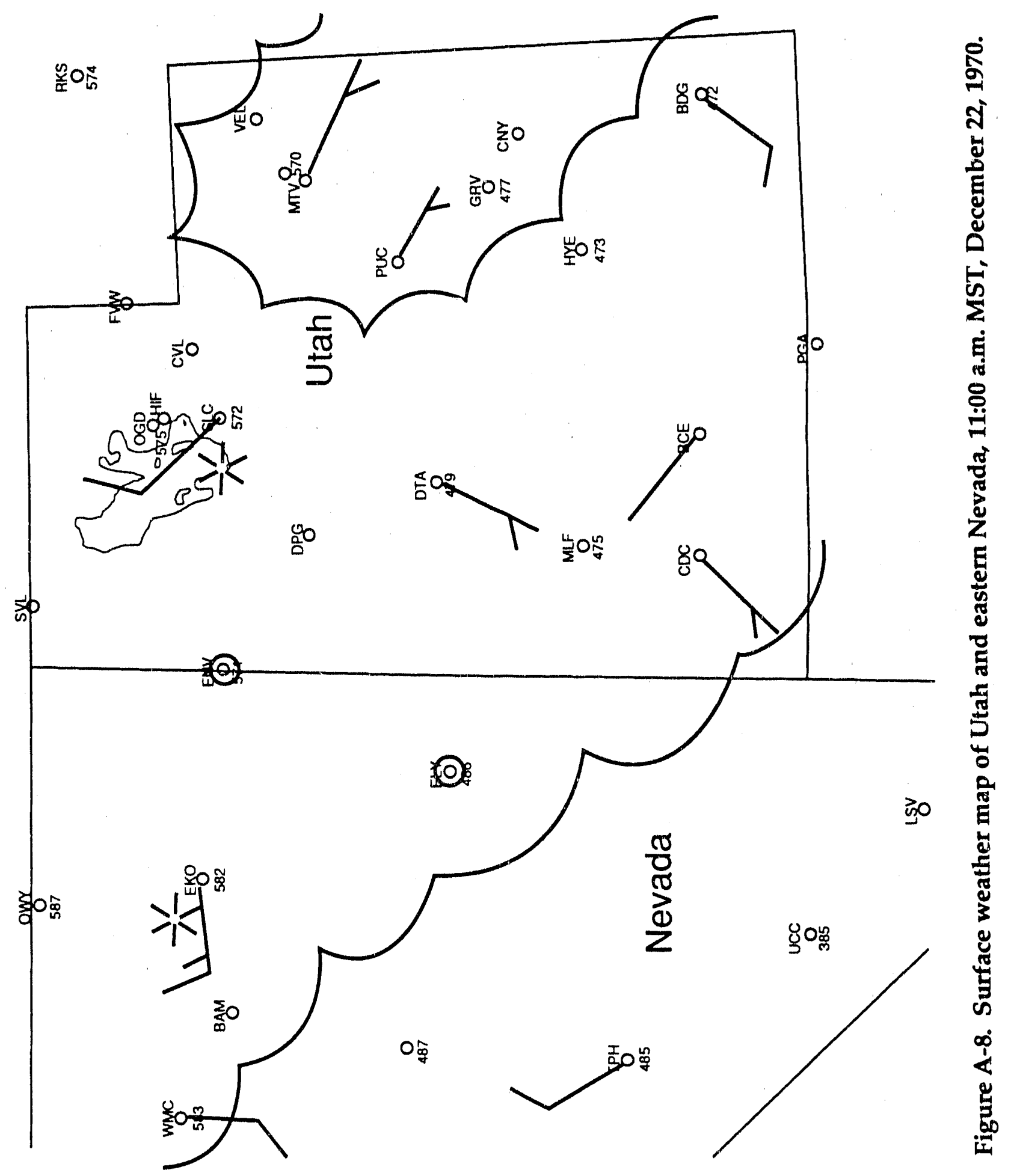




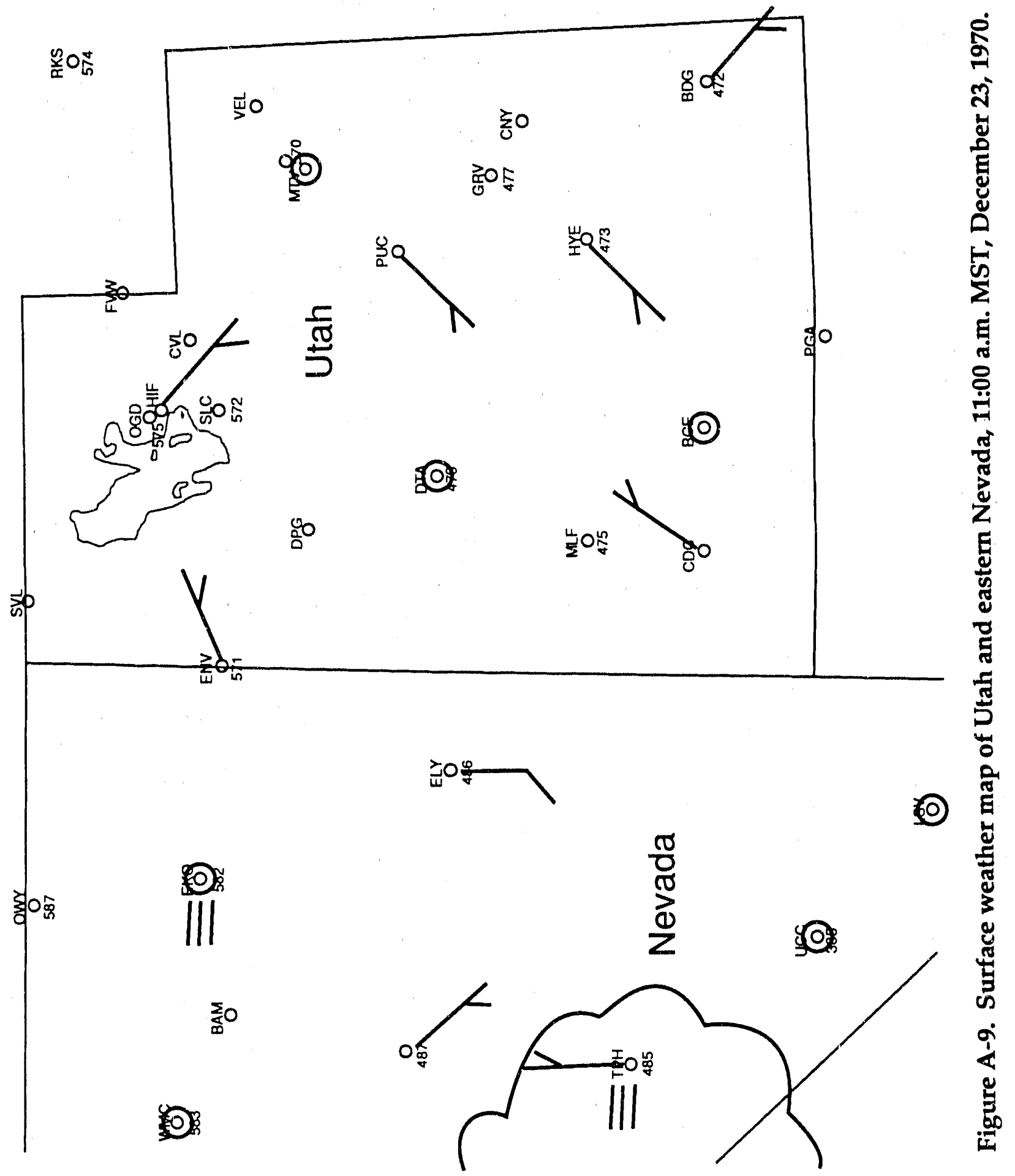




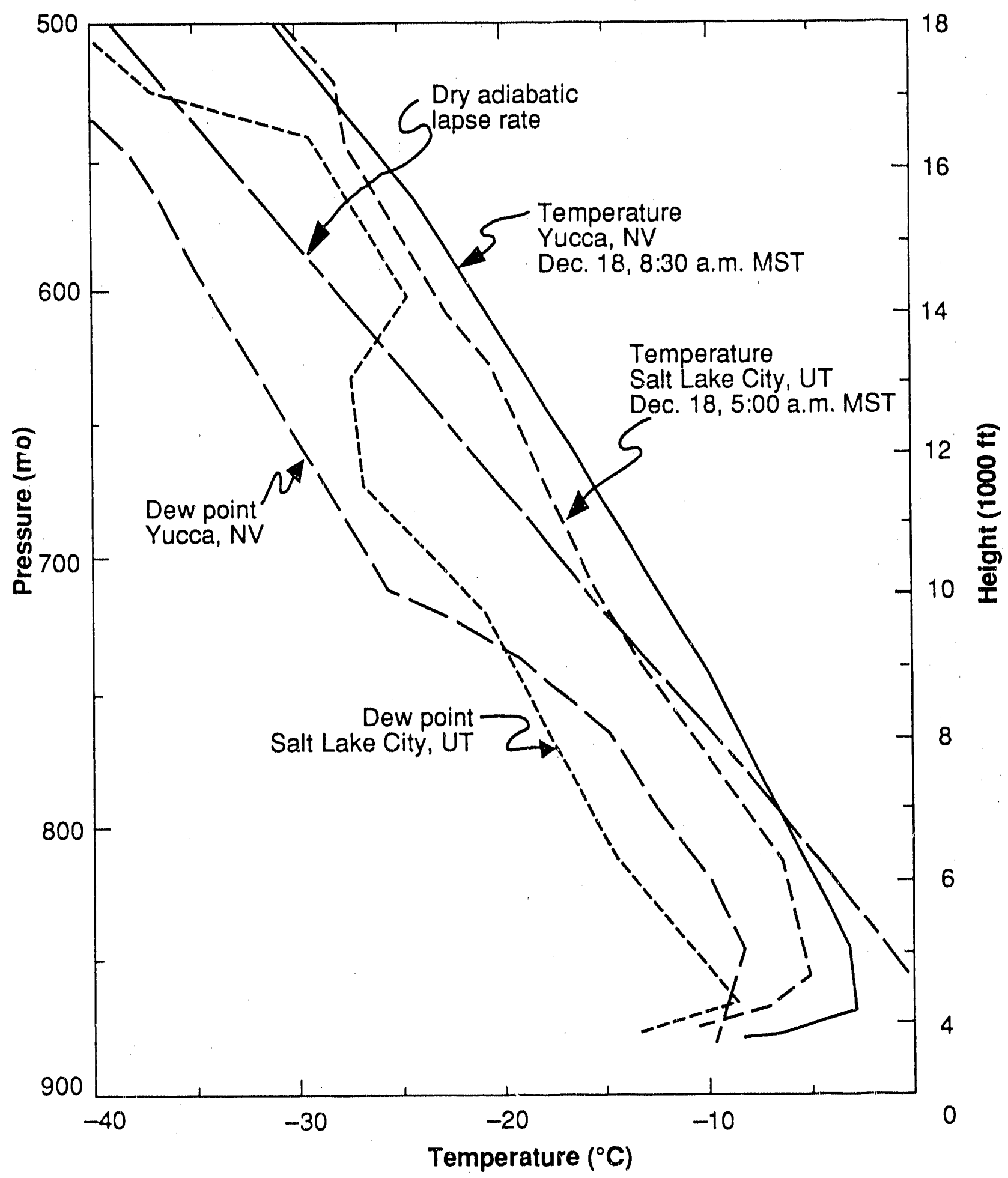

Figure A-11. Temperature and dew point versus height for Yucca, NV, and Salt Lake City, UT. 


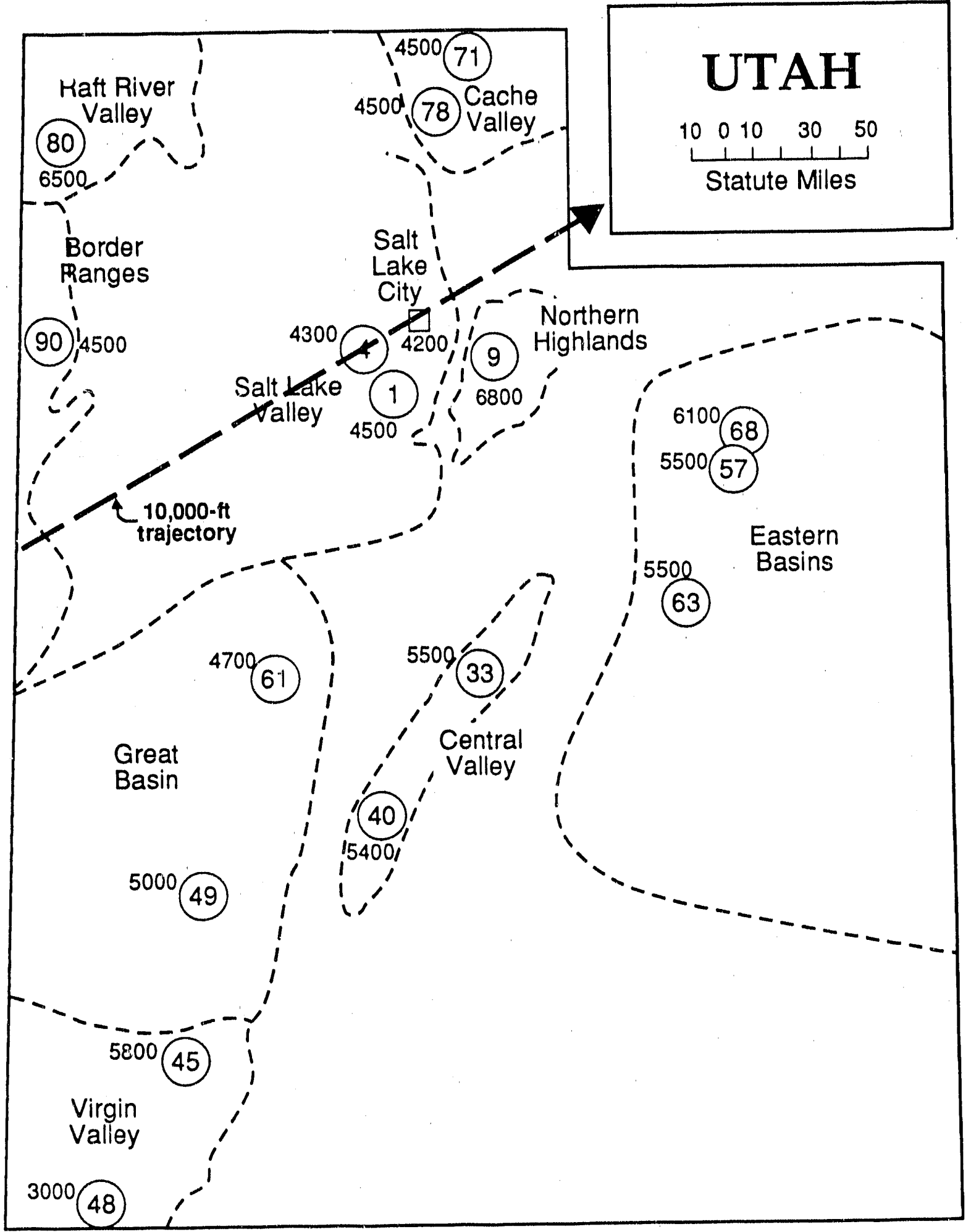

Figure A-12. Location of Utah sampling sites, with their approximate elevations in feet above MSL. 


\section{Appendix B}

\section{Air-Filter Data from Fifteen Collection Sites in Utah}

This appendix contains the air-filter operational times, corresponding air volumes, and concentration of radionuclides from 15 collection sites in Utah. Each of the filters was analyzed in the manner described in the text of this report. Table 1 of the report is repeated here as Table B-1 to help the reader remember the locations of the different sample stations.

Table B-1. Sites in Utah where LRL and University of Utah (U. of U.) air-sampling equipment was in operation, BANEBERRY event, December 18 to 28, 1970.

\begin{tabular}{|c|c|c|c|c|c|c|c|}
\hline $\begin{array}{l}\text { Station } \\
\text { number }\end{array}$ & $\begin{array}{c}\text { Nearest } \\
\text { town }\end{array}$ & $\begin{array}{r}\text { Mile } \\
\text { azi } \\
\text { fror }\end{array}$ & $\begin{array}{l}s \text { and } \\
\text { rnuth } \\
\text { NTS }\end{array}$ & $\begin{array}{c}\text { Type of } \\
\text { farm or site }\end{array}$ & $\begin{array}{l}\text { Number of } \\
\text { livestock }\end{array}$ & $\begin{array}{l}\text { LRL } \\
\text { SAS }\end{array}$ & $\begin{array}{l}U \text {. of U. } \\
\text { Eberline } \\
\text { AIM-3 } 3^{a}\end{array}$ \\
\hline 1 & Draper & 320 & $46^{\circ}$ & Poultry & 0 & $\mathrm{x}$ & $x$ \\
\hline 4 & Magna & 320 & $43^{\circ}$ & Dairy & 80 & $\mathrm{X}$ & $\mathrm{x}$ \\
\hline 9 & Snyderville & 340 & $47^{\circ}$ & Dairy & 50 & $\mathrm{x}$ & $\mathrm{x}$ \\
\hline 33 & Ephraim & 290 & $60^{\circ}$ & Dairy & 30 & $x$ & $\mathrm{x}$ \\
\hline 40 & Monroe & 240 & $68^{\circ}$ & Dairy & 50 & $\mathrm{x}$ & $x$ \\
\hline 45 & Cedar City & 170 & $81^{\circ}$ & Cattle and & 200 & & \\
\hline & & & & sheep & 500 & $\begin{array}{l}x \\
y\end{array}$ & $\begin{array}{l}X \\
y\end{array}$ \\
\hline 48 & St. George & 140 & $95^{\circ}$ & College campus & - & $\mathrm{x}$ & $x$ \\
\hline 49 & Milford & 190 & $67^{\circ}$ & Airport & - & $x$ & $x$ \\
\hline 57 & Bridgeland & 370 & $58^{\circ}$ & Dairy & 120 & $x$ & $\mathrm{X}$ \\
\hline 61 & Delta & 240 & $54^{\circ}$ & $\begin{array}{l}\text { Sugar beet } \\
\text { and alfalfa }\end{array}$ & - & $X$ & 0 \\
\hline 63 & Wellington & 330 & $63^{\circ}$ & Dairy & 80 & $x$ & $x$ \\
\hline 68 & Bluebell & 380 & $56^{\circ}$ & Dairy & 150 & $\mathrm{x}$ & $x$ \\
\hline 71 & Cornish & 390 & $35^{\circ}$ & Dairy & 100 & $x$ & $x$ \\
\hline 78 & Logan & 380 & $36^{\circ}$ & Dairy & 40 & $x$ & $\mathrm{O}$ \\
\hline $80 \mathrm{~A}$ & Grouse Creek & 330 & $22^{\circ}$ & Cattle & 150 & $\mathrm{X}$ & $\mathrm{x}$ \\
\hline 90 & Wendover & 260 & $27^{\circ}$ & Air Force base & - & $x$ & $x$ \\
\hline$C P$ & Salt Lake City & & & $U$. of $U$. campus & - & - & $\mathrm{x}$ \\
\hline
\end{tabular}

a $X=$ functioning equipment; $O=$ nonfunctioning equipment. 
Table B-2. Station Number 1, Draper, Utah. (ND stands for not detectable.)

\begin{tabular}{|c|c|c|c|c|c|c|c|c|}
\hline & \multicolumn{8}{|c|}{ Sample number } \\
\hline & $1 \mathrm{C}^{\mathrm{a}}$ & $2 \mathrm{C}$ & & $3 \mathrm{C}$ & & $4 \mathrm{C}$ & & $5 \mathrm{C}$ \\
\hline \multicolumn{9}{|c|}{ Air filter operational times and corresponding volumes } \\
\hline Start time & $1140 \quad 12-18-70$ & $1440 \quad 12-19-70$ & 0240 & $12-20-70$ & 1440 & $12-20-70$ & 0240 & $12-21-70$ \\
\hline Stop time & $1440 \quad 12-19-70$ & $0240 \quad 12 \cdot 20-70$ & 1440 & $12-20-70$ & 0240 & $12-21-70$ & 1330 & $12-21-70$ \\
\hline Mean sample time & $0110 \quad 12-19-70$ & $20501 ?-19-70$ & 0840 & $12-20-70$ & 2050 & $12-20-70$ & 0805 & $12-21-70$ \\
\hline Elapsed time (h) & 27 & 12 & 12 & & 12 & & $10 \mathrm{~h} 50 \mathrm{r}$ & rnin \\
\hline Total volume $\left(\mathrm{m}^{3}\right)$ & 397 & 162 & 176 & & 207 & & 138 & \\
\hline \multicolumn{9}{|c|}{ Concentration of radionuclides in $\mathrm{pCi} \mathrm{m}^{-3}$ of air corrected to mean sample time } \\
\hline${ }^{76}$ As & 21 & 39 & & 21.1 & & ND & & ND \\
\hline${ }^{99} \mathrm{Mo}$ & 14 & 27 & & 7.2 & & 0.04 & & ND \\
\hline${ }^{103} \mathrm{Ru}$ & 2.7 & 5.1 & & 1.9 & & ND & & ND \\
\hline $122 \mathrm{Sb}$ & 13 & 14.8 & & 4.1 & & 0.15 & & ND \\
\hline $131 \mathrm{~m} \mathrm{Te}$ & 23 & 43 & & 11 & & ND & & ND \\
\hline${ }^{131} 1_{I}$ & 15 & 28 & & 9.3 & & 0.10 & & ND \\
\hline $132 \mathrm{Te}$ & 53 & 99 & & 28 & & 0.15 & & 0.13 \\
\hline${ }^{133} \times \mathrm{e}$ & 43 & 80 & & 29 & & ND & & ND \\
\hline $133_{\mathrm{I}}$ & 130 & 130 & & 12 & & & & \\
\hline
\end{tabular}

a This filter was not analyzed at LRL, the data were estimated upon the ratio of total gamma activity in $1 \mathrm{C}$ and $2 \mathrm{C}$ as reported by the University of Utah.

Table B-3. Station Number 4, Magna, Utah. (ND stands for not detectable.)

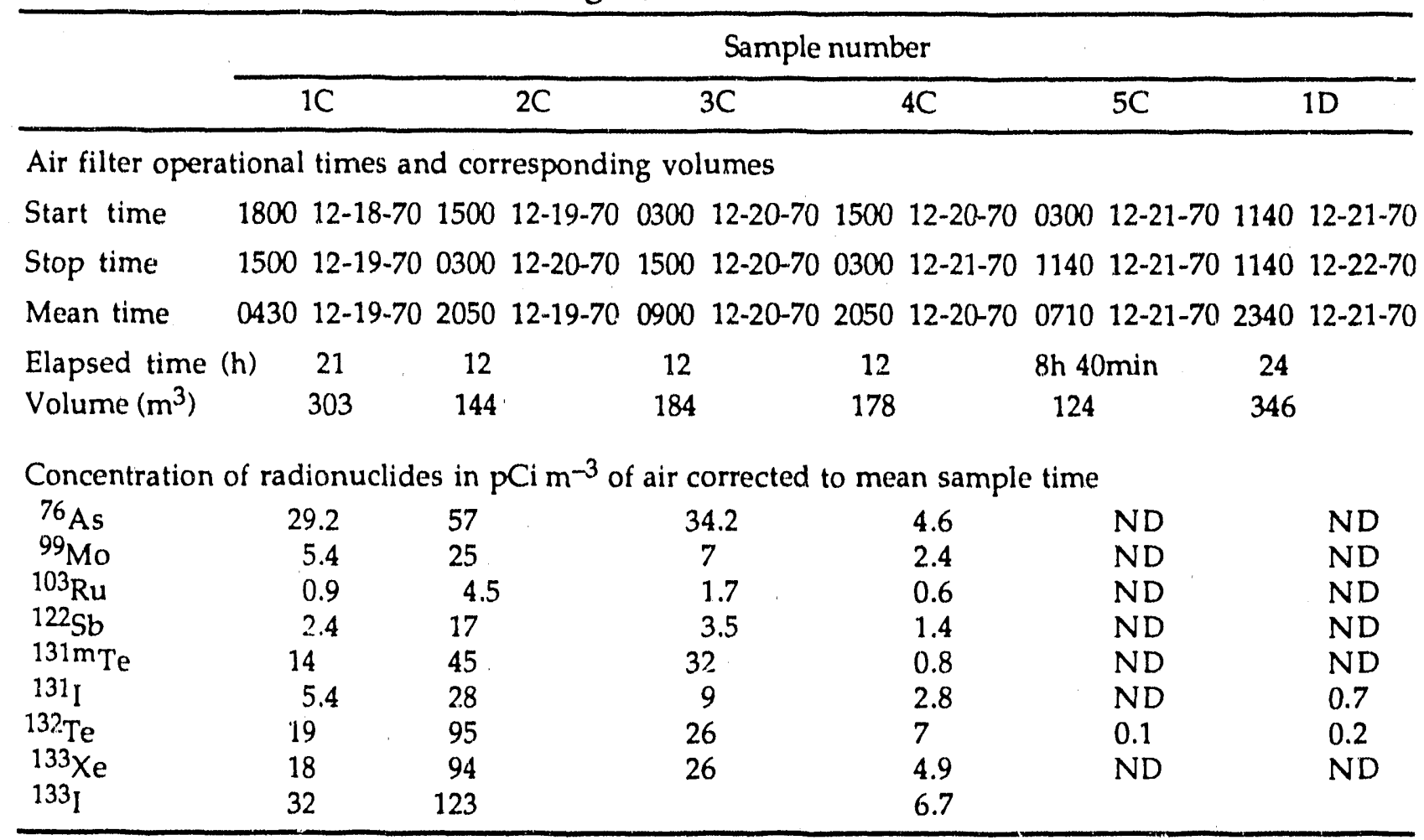


Table B-4. Station Number 9, Snyderville, Utah. (ND stands for not detectable.)

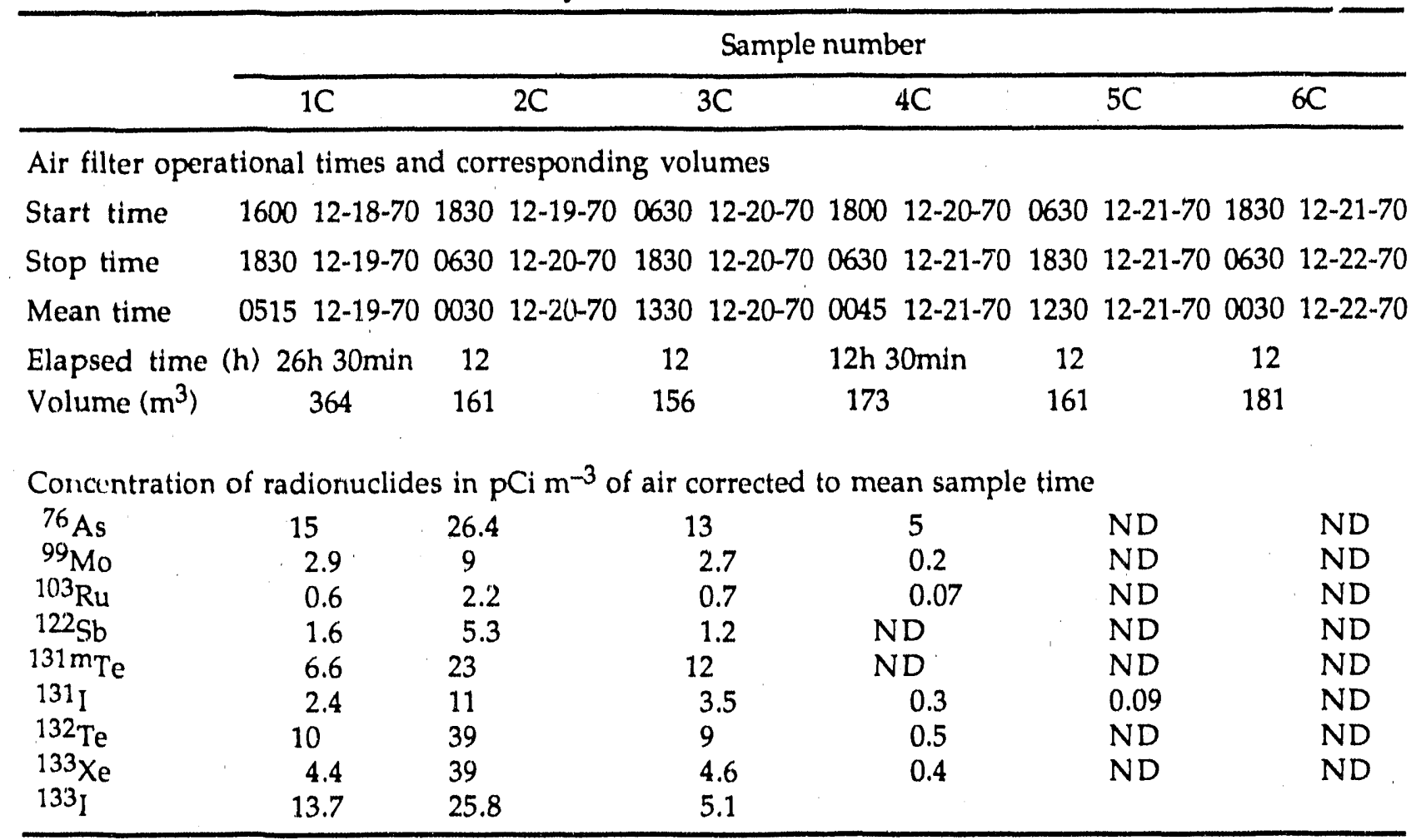

Table B-5. Station Number 33, Ephraim, Utah. (ND stands for not detectable.)

\begin{tabular}{|c|c|c|c|c|}
\hline & \multicolumn{4}{|c|}{ Sample number } \\
\hline & $1 \mathrm{C}$ & $2 \mathrm{C}$ & $3 \mathrm{C}$ & $4 \mathrm{C}$ \\
\hline \multicolumn{5}{|c|}{ Air filter operational times and corresponding volumes } \\
\hline Start time & $1325 \quad 12-18-70$ & $104512-20-70$ & $1325 \quad 12-20-70$ & $132512-21-70$ \\
\hline Stop time & $1045 \quad 12-20-70$ & $1325 \quad 12-20-70$ & $1325 \quad 12-21-70$ & $0935 \quad 12-22-70$ \\
\hline Mean sample time & $1205 \quad 12-19-70$ & $120512-20-70$ & $0125 \quad 12-21-70$ & $233012-21-70$ \\
\hline Elapsed time $(h)$ & $45 \mathrm{~h} 20 \mathrm{~min}$ & $2 \mathrm{~h} 40 \mathrm{~min}$ & 24 & $20 \mathrm{~h} 10 \mathrm{~min}$ \\
\hline Total volume $\left(\mathrm{m}^{3}\right)$ & 890 & 40 & 413 & 343 \\
\hline \multicolumn{5}{|c|}{ Concentration of radionuclides in $\mathrm{pCi} \mathrm{m}^{-3}$ of air corrected to mean sample time } \\
\hline${ }^{76}$ As & 1.3 & ND & ND & ND \\
\hline${ }^{99} \mathrm{Mo}$ & 0.35 & ND & ND & ND \\
\hline${ }^{103} \mathrm{Ru}$ & 0.07 & ND & 0.025 & ND \\
\hline $122 \mathrm{Sb}$ & 0.27 & ND & ND & ND \\
\hline $131 \mathrm{~m} \mathrm{Te}$ & 0.15 & ND & ND & ND \\
\hline${ }^{131}$ I & 0.34 & ND & 0.044 & ND \\
\hline${ }^{132} \mathrm{Te}$ & 1.2 & ND & ND & ND \\
\hline${ }^{133} \mathrm{Xe}$ & 0.68 & ND & ND & ND \\
\hline${ }^{133} \mathrm{I}$ & 1.8 & & & \\
\hline
\end{tabular}


Table B-6. Station Number 40, Monroe, Utah. (ND stands for not detectable.)

\begin{tabular}{|c|c|c|c|c|}
\hline & \multicolumn{4}{|c|}{ Sample number } \\
\hline & $\overline{1 C}$ & $2 \mathrm{C}$ & $3 \mathrm{C}$ & $4 \mathrm{C}$ \\
\hline \multicolumn{5}{|c|}{ Air filter operational times and corresponding volumes } \\
\hline Start time & $1205 \quad 12-18-70$ & $1930 \quad 12-19-70$ & $1205 \quad 12-20-70$ & $120512-21-70$ \\
\hline Stop time & $1930 \quad 12-19-70$ & $120512-20-70$ & $1205 \quad 12-21-70$ & $1205 \quad 12-22-70$ \\
\hline Mean sample time & $0348 \quad 12-19-70$ & $0348 \quad 12-20-70$ & $0005 \quad 12-21-70$ & $0005 \quad 12 \cdots 21-70$ \\
\hline Elapsed time $(\mathrm{h})$ & $31 \mathrm{~h} 25 \mathrm{~min}$ & $16 \mathrm{~h} 35 \mathrm{~min}$ & 24 & 24 \\
\hline Total volume $\left(\mathrm{m}^{3}\right)$ & 446 & 272 & 374 & 365 \\
\hline \multicolumn{5}{|c|}{ Concentration of radionuclides in $\mathrm{pCi} \mathrm{m}^{-3}$ of air corrected to mean sample time } \\
\hline${ }^{76}$ As & ND & ND & ND & ND \\
\hline${ }^{99} \mathrm{Mo}$ & ND & ND & ND & ND \\
\hline${ }^{103} \mathrm{Ru}$ & 0.12 & ND & ND & ND \\
\hline${ }^{122} \mathrm{Sb}$ & ND & ND & ND & ND \\
\hline $131 \mathrm{~m} \mathrm{Te}$ & ND & ND & ND & ND \\
\hline${ }^{131_{I}}$ & 0.45 & 0.16 & ND & ND \\
\hline${ }^{132} \mathrm{Te}$ & 1.3 & ND & ND & ND \\
\hline${ }^{133} \times \mathrm{e}$ & 0.61 & ND & ND & ND \\
\hline
\end{tabular}

Table B-7. Station Number 45, Cedar City, Utah. (ND stands for not detectable.)

\begin{tabular}{|c|c|c|c|c|c|}
\hline & \multicolumn{5}{|c|}{ Sample number } \\
\hline & $\overline{1 C}$ & $2 \mathrm{C}$ & $3 \mathrm{C}$ & $4 \mathrm{C}$ & $5 \mathrm{C}$ \\
\hline \multicolumn{6}{|c|}{ Air filter operational times and corresponding volumes } \\
\hline Start time & $1410 \quad 12-18-70$ & $1445 \quad 12-19-70$ & $1410 \quad 12-20-70$ & $1410 \quad 12-21-70$ & $1410 \quad 12-22-70$ \\
\hline Stop time & $1445 \quad 12-19-70$ & $1410 \quad 12-20-70$ & $1410 \quad 12-21-70$ & $1410 \quad 12-22-70$ & $0930 \quad 12-23-70$ \\
\hline Mean sample time & $0227 \quad 12-19-70$ & $0227 \quad 12-20-70$ & $0210 \quad 12-21-70$ & $0210 \quad 12-22-70$ & $2350 \quad 12-22-70$ \\
\hline Elapsed time $(\mathrm{h})$ & $24 \mathrm{~h} 35 \mathrm{~min}$ & $23 \mathrm{~h} 25 \mathrm{~min}$ & 24 & 24 & 19h 20min \\
\hline Total volume $\left(\mathrm{m}^{3}\right)$ & 364 & 375 & 341 & 307 & 302 \\
\hline \multicolumn{6}{|c|}{ Concentration of radionuclides in $\mathrm{pCi} \mathrm{m}^{-3}$ of air corrected to mean sample time } \\
\hline${ }^{76}$ As & ND & ND & ND & ND & ND \\
\hline${ }^{99} \mathrm{Mo}$ & ND & 0.88 & ND & ND & ND \\
\hline${ }^{103} \mathrm{Ru}$ & ND & 0.20 & ND & ND & ND \\
\hline $122 \mathrm{Sb}$ & ND & ND & ND & ND & ND \\
\hline $131 \mathrm{~m} \mathrm{Te}$ & ND & ND & ND & ND & ND \\
\hline${ }^{131} 1_{I}$ & ND & 0.74 & ND & ND & ND \\
\hline${ }^{132} \mathrm{Te}$ & ND & 2.7 & ND & ND & ND \\
\hline${ }^{133} \mathrm{Xe}$ & ND & 1.6 & ND & ND & ND \\
\hline
\end{tabular}


Table B-8. Station Number 48, St. George, Utah. (ND stands for not detectable.)

\begin{tabular}{|c|c|c|c|c|c|}
\hline & \multicolumn{5}{|c|}{ Sample number } \\
\hline & $1 \mathrm{C}^{\mathrm{a}}$ & $2 \mathrm{C}$ & $3 \mathrm{C}$ & $\overline{4 C}$ & $5 \mathrm{C}$ \\
\hline \multicolumn{6}{|c|}{ Air filter operational times and corresponding volumes } \\
\hline Start time & $1400 \quad 12-18-70$ & $1400 \quad 12-19-70$ & $1400 \quad 12-20-70$ & $140012-21-70$ & $1400 \quad 12-22-70$ \\
\hline Stop time & $1400 \quad 12-19-70$ & $1400 \quad 12-20-70$ & $1400 \quad 12-21-70$ & $1400 \quad 12-22-70$ & $1705 \quad 12-22-70$ \\
\hline Mean sample time & $0200 \quad 12-19-70$ & $0200 \quad 12-20-70$ & $0200 \quad 12-21-70$ & $0200 \quad 12-22-70$ & $1533 \quad 12-22-70$ \\
\hline Elapsed time $(\mathrm{h})$ & 24 & 24 & 24 & 24 & $3 \mathrm{~h} 5 \mathrm{~min}$ \\
\hline Total volume $\left(\mathrm{m}^{3}\right)$ & 360 & 360 & 369 & 360 & 45 \\
\hline \multicolumn{6}{|c|}{ Concentration of radionuclides in $\mathrm{pCi} \mathrm{m}^{-3}$ of air corrected to mean sample time } \\
\hline${ }^{76} \mathrm{As}$ & ND & ND & ND & ND & ND \\
\hline${ }^{99} \mathrm{Mo}$ & ND & ND & ND & ND & ND \\
\hline${ }^{103} \mathrm{Ru}$ & ND & ND & ND & ND & ND \\
\hline $122 \mathrm{Sb}$ & ND & ND & ND & ND & ND \\
\hline $131 \mathrm{mTe}$ & ND & ND & ND & ND & ND \\
\hline $131_{I}$ & ND & ND & ND & ND & ND \\
\hline${ }^{132} \mathrm{Te}$ & ND & ND & ND & ND & ND \\
\hline${ }^{133} \times \mathrm{e}$ & ND & ND & ND & ND & ND \\
\hline
\end{tabular}

Table B-9. Station Number 49, Milford, Utah. (ND stands for not detectable.)

\begin{tabular}{|c|c|c|c|c|}
\hline & \multicolumn{4}{|c|}{ Sample number } \\
\hline & $1 \mathrm{C}$ & $2 \mathrm{C}$ & $3 \mathrm{C}$ & $4 \mathrm{C}$ \\
\hline \multicolumn{5}{|c|}{ Air filter operational times and corresponding volumes } \\
\hline Start time & $1300 \quad 12-18-70$ & $1300 \quad 12-19-70$ & $1300 \quad 12-20-70$ & $1300 \quad 12-21-70$ \\
\hline Stop time & $1300 \quad 12-19-70$ & $1300 \quad 12-20-70$ & $1300 \quad 12-21-70$ & $1300 \quad 12-22-70$ \\
\hline Mean sample time & $0100 \quad 12-19-70$ & $0100 \quad 12-20-70$ & $0100 \quad 12-21-70$ & $0100 \quad 12-22-70$ \\
\hline Elapsed time $(\mathrm{h})$ & 24 & 24 & 24 & 24 \\
\hline Total volume $\left(\mathrm{m}^{3}\right)$ & 387 & 125 & 387 & 387 \\
\hline \multicolumn{5}{|c|}{ Concentration of radionuclides in $\mathrm{pCi} \mathrm{m}^{-3}$ of air corrected to mean sample time } \\
\hline${ }^{76}$ As & ND & ND & ND & ND \\
\hline${ }^{99} \mathrm{Mo}$ & ND & ND & ND & ND \\
\hline${ }^{103} \mathrm{Ru}$ & 0.06 & 0.16 & ND & ND \\
\hline $122 \mathrm{Sb}$ & ND & ND & ND & ND \\
\hline $131 \mathrm{~m} \mathrm{Te}$ & ND & ND & ND & ND \\
\hline${ }^{131}$ I & 0.25 & 0.64 & ND & ND \\
\hline${ }^{132} \mathrm{Te}$ & ND & 2.1 & ND & ND \\
\hline${ }^{133} \mathrm{Xe}$ & ND & 1.04 & ND & ND \\
\hline
\end{tabular}


Table B-10. Station Number 57, Bridgeland, Utah. (ND stands for not detectable.)

Sample number

$2 \mathrm{C}$

Air filter operational times and corresponding volumes

Start time

$0920 \quad 12-26-70$

Stop time

$1510 \quad 12-28-70$

Mean sample time

$1215 \quad 12-27-70$

Elapsed time $(h)$

$53 \mathrm{~h}$ 50min

Total volume $\left(\mathrm{m}^{3}\right)$

883

Concentration of raciionuclides in $\mathrm{pCi} \mathrm{m}^{-3}$ of air corrected to mean sample time

$\begin{array}{lc}{ }^{76} \mathrm{As} & \mathrm{ND} \\ { }^{99} \mathrm{Mo} & \mathrm{ND} \\ { }^{103} \mathrm{Ru} & 0.0015 \\ { }^{122} \mathrm{Sb} & 0.0065 \\ 131 \mathrm{~m} \mathrm{Te} & \mathrm{ND} \\ 131 \mathrm{I} & 0.0071 \\ { }^{132} \mathrm{Te} & \mathrm{ND} \\ 133 \mathrm{Xe} & \mathrm{ND}\end{array}$

Table B-11. Station Number 61, Delta, Utah. (ND stands for not detectable.)

\begin{tabular}{|c|c|c|c|c|}
\hline & \multicolumn{4}{|c|}{ Sample number } \\
\hline & $1 \mathrm{C}$ & $2 \mathrm{C}$ & $3 C$ & $4 \mathrm{C}$ \\
\hline \multicolumn{5}{|c|}{ Air filter operational times and corresponding volumes } \\
\hline Start time & $1500 \quad 12-18-70$ & $1400 \quad 12-19-70$ & $1400 \quad 12-20-70$ & $1400 \quad 12-21-70$ \\
\hline Stop time & $1400 \quad 12-19-70$ & $1400 \quad 12-20-70$ & $1400 \quad 12-21-70$ & $1400 \quad 12-22-70$ \\
\hline Mean sample time & $0230 \quad 12-19-70$ & $0200 \quad 12-20-70$ & $020012 \cdot 21-70$ & $0200 \quad 12-22-70$ \\
\hline Flapsed time (h) & 23 & 24 & 24 & 24 \\
\hline Total volume $\left(\mathrm{m}^{3}\right)$ & 371 & 358 & 368 & 401 \\
\hline \multicolumn{5}{|c|}{ Concentration of radionuclides in $\mathrm{pCi} \mathrm{m} \mathrm{m}^{-3}$ of air corrected to mean sample time } \\
\hline${ }^{76} \mathrm{As}$ & ND & ND & ND & ND \\
\hline${ }^{99} \mathrm{Mo}$ & ND & ND & ND & ND \\
\hline${ }^{103} \mathrm{Ru}$ & ND & 0.14 & 0.044 & ND \\
\hline $122 \mathrm{Sb}$ & ND & ND & ND & ND \\
\hline $131 \mathrm{~m} \mathrm{Te}$ & ND & ND & ND & ND \\
\hline${ }^{131} 1_{I}$ & ND & 0.55 & ND & ND \\
\hline${ }^{132} \mathrm{Te}$ & ND & 1.8 & ND & ND \\
\hline${ }^{133} \times \mathrm{e}$ & ND & 0.85 & ND & ND \\
\hline
\end{tabular}


Table B-12. Station Number 68, Bluebell, Utah. (ND stands for not detectalia.)

\begin{tabular}{|c|c|c|}
\hline & \multicolumn{2}{|c|}{ Sample number } \\
\hline & $\overline{1 C}$ & $2 \mathrm{C}$ \\
\hline \multicolumn{3}{|c|}{ Air filter operational times and corresponding volumes } \\
\hline Start time & $142012-18-70$ & $142012-25-70$ \\
\hline Stop time & $1420 \quad 12-25-70$ & $162012-28-70$ \\
\hline Mean sample time & $0220 \quad 12-22-70$ & $0320 \quad 12-27-70$ \\
\hline Elapsed time (h) & 168 & 74 \\
\hline Total volume $\left(\mathrm{m}^{3}\right)$ & 2445 & 1119 \\
\hline \multicolumn{3}{|c|}{ Concentration of radionuclides in $\mathrm{pCi} \mathrm{m}^{-3}$ of air corrected to mean sample time } \\
\hline${ }^{76} \mathrm{As}$ & ND & ND \\
\hline${ }^{99} \mathrm{Mo}$ & ND & ND \\
\hline${ }^{103} \mathrm{Ru}$ & 0.035 & ND \\
\hline $122 \mathrm{Sb}$ & ND & ND \\
\hline $131 \mathrm{~m} \mathrm{Te}$ & ND & ND \\
\hline${ }^{131} 1_{I}$ & 0.144 & ND \\
\hline${ }^{132} \mathrm{Te}$ & 0.54 & ND \\
\hline${ }^{133} \times \mathrm{e}$ & 0.683 & ND \\
\hline
\end{tabular}

Table B-13. Station Number 71, Cornish, Utah. (ND stands for not detectable.)

\begin{tabular}{|c|c|c|c|c|c|}
\hline & \multicolumn{5}{|c|}{ Sample number } \\
\hline & & $1 \mathrm{~B}$ & $2 \mathrm{~B}$ & $3 \mathrm{~B}$ & 4B \\
\hline \multicolumn{6}{|c|}{ Air filter operational times and corresponding volumes } \\
\hline Start time & 1615 & $12-18-70$ & $1515 \quad 12-21-70$ & $1515 \quad 12-22-70$ & $1515 \quad 12-23-70$ \\
\hline Stop time & 1515 & $12-21-70$ & $1515 \quad 12-22-70$ & $1515 \quad 12-23-70$ & $1515 \quad 12-24-70$ \\
\hline Mean sample time & 0345 & $12-20-70$ & $0315 \quad 12-22-70$ & $0315 \quad 12-23-70$ & $0315 \quad 12-24-70$ \\
\hline Elapsed time $(\mathrm{h})$ & 71 & & 24 & 24 & 24 \\
\hline Total volume $\left(\mathrm{m}^{3}\right)$ & 1130 & & 362 & 380 & 343 \\
\hline \multicolumn{6}{|c|}{ Concentration of radionuclides in $\mathrm{pCi} \mathrm{m}^{-3}$ of air corrected to mean sample time } \\
\hline${ }^{76} \mathrm{As}$ & 12 & & ND & ND & ND \\
\hline${ }^{99} \mathrm{Mo}$ & & 3.5 & ND & ND & ND \\
\hline${ }^{103} \mathrm{Ru}$ & & 0.82 & 0.06 & ND & ND \\
\hline $122 \mathrm{Sb}$ & & 1.8 & ND & ND & ND \\
\hline $131 \mathrm{mTe}$ & & 6.0 & ND & ND & ND \\
\hline${ }^{131} \mathrm{I}$ & & 3.6 & 0.26 & ND & 0.31 \\
\hline${ }^{132} \mathrm{Te}$ & 1 & 2 & ND & ND & ND \\
\hline${ }^{133} \lambda^{\prime} \mathrm{e}$ & & 5.4 & 3.93 & ND & ND \\
\hline${ }^{133}$ I & & 3.4 & ND & ND & ND \\
\hline
\end{tabular}


Table B-14. Station Number 78, Logan, Utah. (ND stands for not detectable.)

\begin{tabular}{|c|c|c|c|c|}
\hline & \multicolumn{4}{|c|}{ Sample number } \\
\hline & $1 \mathrm{C}$ & $\overline{2 C}$ & $3 \mathrm{C}$ & $4 \mathrm{C}$ \\
\hline \multicolumn{5}{|c|}{ Air filter operational times and corresponding volumes } \\
\hline Start time & $1700 \quad 12-18-70$ & $1430 \quad 12-19-70$ & $1400 \quad 12-21-70$ & $1400 \quad 12-22-70$ \\
\hline Stop time & $1430 \quad 12-19-70$ & $140012-21-70$ & $1400 \quad 12-22-70$ & $1400 \quad 12-23-70$ \\
\hline Mean sample time & $0345 \quad 12-19-70$ & $1415 \quad 12-20-70$ & $0200 \quad 12-22-70$ & $0200 \quad 12-23-70$ \\
\hline Elapsed time $(\mathrm{h})$ & $21 \mathrm{~h} 30 \mathrm{~min}$ & $47 \mathrm{~h} 30 \mathrm{~min}$ & 24 & 24 \\
\hline Total volume $\left(\mathrm{m}^{3}\right)$ & 342 & 795 & 380 & 422 \\
\hline \multicolumn{5}{|c|}{ Concentration of radionuclides in $\mathrm{pCi} \mathrm{m}^{-3}$ of air corrected to mean sample time } \\
\hline${ }^{76}$ As & ND & 16 & ND & ND \\
\hline${ }^{99} \mathrm{Mo}$ & ND & 6 & ND & ND \\
\hline${ }^{103} \mathrm{Ru}$ & ND & 1.6 & ND & 0.03 \\
\hline $122 \mathrm{Sb}$ & ND & 2.8 & ND & ND \\
\hline $131 \mathrm{~m}_{\mathrm{Te}}$ & ND & 11 & ND & ND \\
\hline${ }^{131_{I}}$ & ND & 6.6 & ND & 0.23 \\
\hline${ }^{132} \mathrm{Te}$ & ND & 20 & ND & ND \\
\hline${ }^{133} \mathrm{Xe}$ & ND & 9.6 & ND & ND \\
\hline${ }^{133} I$ & ND & 10.4 & ND & ND \\
\hline
\end{tabular}

Table B-15. Station Number 80A, Grouse Creek, Utah (ND stands for not detectable.)

\begin{tabular}{|c|c|c|}
\hline & \multicolumn{2}{|c|}{ Sample number } \\
\hline & $\overline{1 C}$ & $2 \mathrm{C}$ \\
\hline \multicolumn{3}{|c|}{ Air filter operational times and corresponding volumes } \\
\hline Start time & $144512-18-70$ & $144512-25-70$ \\
\hline Stop time & $144512-25-70$ & $1245 \quad 12-26-70$ \\
\hline Mean sample time & $0245 \quad 12-22-70$ & $014512-26-70$ \\
\hline Elapsed time $(h)$ & 168 & 22 \\
\hline Total volume $\left(\mathrm{m}^{3}\right)$ & 2754 & 352 \\
\hline \multicolumn{3}{|c|}{ Concentration of radionuclides in $\mathrm{pCi} \mathrm{m}^{-3}$ of air corrected to mean sample time } \\
\hline${ }^{76}$ As & ND & ND \\
\hline${ }^{99} \mathrm{Mo}$ & 0.17 & ND \\
\hline${ }^{103} \mathrm{Ru}$ & 0.24 & ND \\
\hline${ }^{122} \mathrm{Sb}$ & ND & ND \\
\hline $131 \mathrm{~m} \mathrm{Te}$ & ND & ND \\
\hline${ }^{131} I$ & 0.89 & 0.048 \\
\hline${ }^{132} \mathrm{Te}$ & 2.3 & ND \\
\hline${ }^{133} \mathrm{Xe}$ & 1.5 & ND \\
\hline
\end{tabular}


Table B-16. Station Number 90, Wendover, Utah. (ND stands for not detectable.)

Sample number

\begin{tabular}{lllll}
\hline $1 \mathrm{C}$ & $2 \mathrm{C}$ & $3 \mathrm{C}$ & $4 \mathrm{C}$ & $5 \mathrm{C}$ \\
\hline
\end{tabular}

Air filter operational times and corresponding volumes

Start time

$1305 \quad 12-18-70 \quad 1310 \quad 12-19-70$

$0900 \quad 12-21-70 \quad 2200 \quad 12-21-70$

$0800 \quad 12-22-70$

Stop time

$\begin{array}{lllll}1310 & 12-19-70 & 0900 & 12-21-70\end{array}$

$\begin{array}{lllll}2200 & 12-21-70 & 0800 & 12-22-70\end{array}$

$2000 \quad 12-22-70$

Mean sample time

$0108 \quad 12-19-70$

$1105 \quad 12-20-70$

$1530 \quad 12-21-70$

$0300 \quad 12-22-70$

$1400 \quad 12-22-70$

Elapsed time (h)

$24 \mathrm{~h} 5 \mathrm{~min}$

$43 \mathrm{~h} 50 \mathrm{~min}$

13

10

12

Total volume $\left(\mathrm{m}^{3}\right)$

419

678

221

151

165

Concentration of radionuclides in $\mathrm{pCi} \mathrm{m}^{-3}$ of air corrected to mean sample time

\begin{tabular}{lccccc}
${ }^{76} \mathrm{As}$ & ND & ND & ND & ND & ND \\
$99 \mathrm{Mo}$ & ND & 3.4 & ND & ND & ND \\
$103 \mathrm{Ru}$ & ND & 0.82 & 0.74 & 0.55 & 0.99 \\
$122 \mathrm{Sb}$ & ND & 3.02 & ND & ND & ND \\
$131 \mathrm{~m} \mathrm{Te}$ & ND & ND & ND & ND & ND \\
$131_{\mathrm{I}}$ & ND & 4.01 & 3.1 & 2.1 & 3.8 \\
$132 \mathrm{Te}$ & ND & 13 & ND & ND & ND \\
$133 \mathrm{Xe}$ & ND & 12.4 & 19.2 & 32.7 & 27.2 \\
\hline
\end{tabular}




\section{Appendix C}

\section{Preliminary Results on Selected Samples of Biological Materials from Nevada Test Site \\ G.B. Potter}

As part of our investigation of the BANEBERRY event, we obtained samples of milk and other biological materials from various locations in Nevada, both on and off the Nevada Test Site. In this appendix, we present some of our measurements from these samples.

\section{Off-Site Milk Samples}

Three off-site milk samples were obtained from Dick Jacquish of SWRHL, Las Vegas. These consisted of milk obtained from Sharp's Ranch near Nyala on December 19, 1970, from Halsted's Ranch near Duckwater collected on the same day, and from a location near Springdale collected on December 26, 1970. Sharp's Ranch is located about 70 miles north of the release, the Halsted Ranch about 120 miles north of the release near Highway 20, and Springdale is about 50 miles west of the release on Highway 95.

All milk samples were counted for $11.1 \mathrm{~h}(40,000 \mathrm{sec})$ on a $\mathrm{Ge}(\mathrm{Li})$ detector. No debris radionuclides were observed in the milk from Sharp's Ranch. In contrast, the milk sample from the Halsted Ranch (near Duckwater) contained $66.7 \mathrm{pCi} \mathrm{kg}^{-1}$ of 131 I; no other debris radionuclides were observed in this milk. The milk sample from Springdale contained $1550 \mathrm{pCi}$ of ${ }^{131} \mathrm{I}$ per liter.

\section{On-Site Studies at Nevada Test Site}

A cooperative arrangement was made with Drs. R. Stanley and A. Moghissi of SWRHL to obtain samples of milk, urine, feces, blood, and hay from contaminated cows near well $15 \mathrm{~d}$ at the Nevada Test Site (NTS). In addition, tissues from two calves in the same area were obtained.

All samples were counted on high-resolution $\mathrm{Ge}(\mathrm{Li})$ detectors for gammaemitting radionuclides that were individually quantified. 


\section{Methods}

Samples sent to LRL from NTS were placed in 200-mL aluminum cans to which formalin was added as a preservative and sealed. Small tissue samples, such as thyroid glands, were minced and suspended in a $2 \%$ agar solution to ensure uniform counting geometry. Most of the samples were counted for $11.1 \mathrm{~h}$ $(40,000 \mathrm{sec})$ each.

The three different $\mathrm{Ge}(\mathrm{Li})$ counters were cross-calibrated. The resulting gammaray spectra were recorded on magnetic tape and processed by computer to obtain the amounts of different radionuclides in $\mathrm{pCi} \mathrm{kg}^{-1}$. Serious limitations in the quantification of the radionuclides were the long count times required for such low levels of radioactivity, the short half-lives of some of the radionuclides, and the large number of samples (approximately 125).

\section{Cow-Metabolism Studies}

We received and counted the samples from five cows. No debris radionuclides were observed in the blood, possibly because the individual samples were too small to obtain adequate counts.

Hay contained the following radionuclides: ${ }^{76} \mathrm{As},{ }^{99} \mathrm{Mo},{ }^{103} \mathrm{Ru},{ }^{122} \mathrm{Sb},{ }^{132} \mathrm{Te},{ }^{131} \mathrm{I}$, ${ }^{133} \mathrm{I},{ }^{133} \mathrm{Xe}$, and ${ }^{239} \mathrm{~Np}$. (Only ${ }^{131} \mathrm{I}$ was found in significant amounts in hay in Utah.) The radionuclides present in milk :vere ${ }^{99} \mathrm{Mo},{ }^{131} \mathrm{I}$, and ${ }^{133} \mathrm{I}$. The levels of ${ }^{133} \mathrm{I}$ in milk were about 25 times those of ${ }^{131} \mathrm{I}$ in the milk. This is in contrast to the Utah milk measurements where ${ }^{131}$ I concentrations were higher.

Radionuclides observed in feces include ${ }^{99} \mathrm{Mo},{ }^{103} \mathrm{Ru},{ }^{122} \mathrm{Sb},{ }^{132} \mathrm{Te},{ }^{131} \mathrm{I},{ }^{133} \mathrm{Xe}$, and ${ }^{239} \mathrm{~Np}$. However, ${ }^{133}$ I was not observed in feces.

\section{Calf-Tissue Studies}

Tissues from two calves sacrificed on December 23, 1970, were also analyzed. The tissues included lung, bone, plasma, red blood cells (RBC), muscle, liver, kidney, skin, and thyroid gland. Total weights of bone, plasma, RBC, and muscle were estimated from relationships of organ to total body weights.

We observed ${ }^{76}$ As only in kidney. Most tissues other than the thyroid contained ${ }^{99} \mathrm{Mo}$. We observed ${ }^{103} \mathrm{Ru}$ only in skin, hay, and feces; ${ }^{239} \mathrm{~Np}$ was observed only in kidney and skin. Levels of 133 I were about two times those of ${ }^{131} \mathrm{I}$ in the thyroid of this calf. 

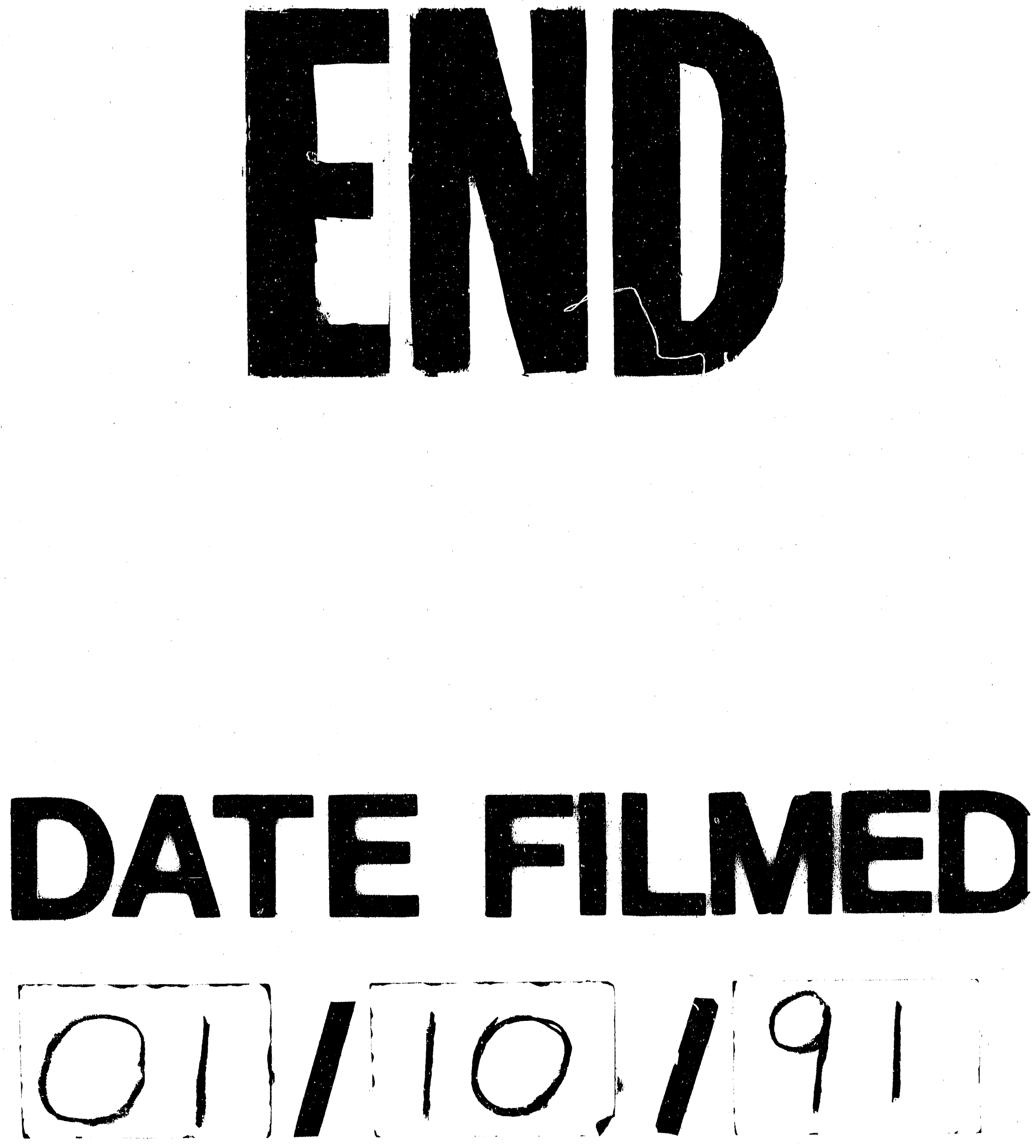
